WHC-EP-0813

UC- 630

\title{
Ground Water Impact Assessment Report for the 216-B-3 Pond System
}
V. G. Johnson
S. D. Evelo
A. G. Law
D. B. Barnett
S. P. Reidel
M. D. Sweeney

Date Published

January 1995

Prepared for the U.S. Department of Energy Office of Environmental Restoration and

Waste Management

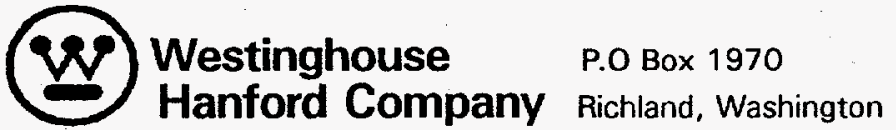

Hanford Operations and Engineering Contractor for the

U.S. Department of Energy under Contract DE-ACO6-87RL10930

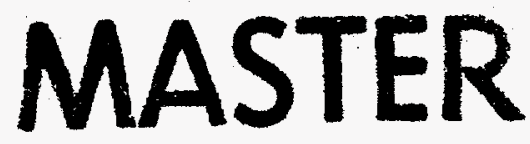

Approved for Public Release 


\section{RELEASE AUTHORIZATION}

Document Number: WHC-EP-0813

Document Title:

Ground Water Impact Assessment Report for the 216-B3 Pond

Release Date:

$12 / 21 / 94$

This document was reviewed following the procedures described in WHC-CM-3-4 and is:

APPROVED FOR PUBLIC RELEASE

WHC Information Release Administration Specialist:

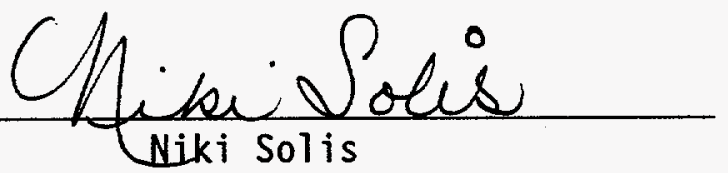

$12 / 21 / 94$

Niki Sol is 


\section{DISCLAIMER}

Portions of this document may be illegible in electronic image products. Images are produced from the best available original document. 


\section{EXECUTIVE SUMMARY}

Ground water impact assessments were required for a number of 1 iquid effluent receiving sites according to the Hanford Federal Facility Agreement and Consent Order ${ }^{1}$ Milestones $M-17-00 A$ and $M-17-00 B$, as agreed upon by the U.S. Department of Energy. This report is one of the last three assessments required and addresses the impact of continued discharge of uncontaminated wastewater to the 216-B-3C expansion lobe of the B Pond system in the 200 East Area until June 1997.

Evaluation of past and projected effluent volumes and composition, geohydrology of the receiving site, and contaminant plume distribution patterns, combined with ground water modeling, were used to assess both changes in ground water flow regime and contaminant-related impacts. Conclusions are summarized as follows:

- Changes in the ground water flow regime will be minor. The ground water modeling indicates there should be very little change in the existing flow regime beneath and in the vicinity of the 200 East Area during the period of interest for this report.

- Contaminant-related impacts are minimal. The only potential contaminant impacts identified involved potential remobilization of adjacent soil column contaminants by the new ground water "mound."

${ }^{1}$ Ecology, EPA, and DOE, 1992, Hanford Federal Facility Agreement and Consent Order, Washington State Department of Ecology, U.S. Environmental Protection Agency, and U.S. Department of Energy, 0lympia, Washington. 
Based on the modeling results and time series plots of water level in selected wells, it was concluded that a decrease in mound height is expected and, therefore, no additional contaminants would be introduced to ground water.

- Effects of continued discharge until 1997 are negligible. The major effects of continued discharge to $216-B-3 C$ are (1) dilution and extended areal dispersion of existing ground water contaminant plumes and (2) restriction of contaminant plume movement to the southeast. The long-term impact of discharges to either the 216-B-3C expansion lobe of the B Pond system, or to the proposed replacement ( $W-049 \mathrm{H}$ discharge site immediately east of the 216-B-3C expansion lobe) is a major issue that will be addressed in future updates of the Hanford Sitewide Groundwater Remediation Strategy ${ }^{2}$ and the Hanford Site Ground Water Protection Plan. ${ }^{3}$ The ground water modeling approach developed for this assessment will be directly applicable in evaluation of various ground water management options associated with long-term discharges to the $216-B-3 C$ expansion lobe or its replacement.

${ }^{2}$ Knepp, A. J., B. H. Ford, D. K. Tyler, F. N. Hodges, V. G. Johnson, R. E. Peterson, and G. L. Kasza, 1994, Hanford Sitewide Groundwater. Remediation Strategy, DOE/RL-94-95, Draft A, U.S. Department of Energy, Richland Operations Office, Richland, Washington.

${ }^{3} \mathrm{DOE}-\mathrm{RL}, 1994 \mathrm{C}$, Hanford Site Ground Water Protection Management Plan, DOE/RL-89-12, Revision 2, Draft A, U.S. Department of Energy, Richland Operations Office, Richland, Washington. 


\section{CONTENTS}

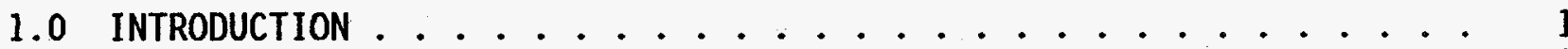

1.1 BACKGROUND ........................ . . . . 1

1.2 METHODOLOGY . . . . . . . . . . . . . . . . . . . . . 1

$2.0 \quad 216-B-3$ POND DESCRIPTION . . . . . . . . . . . . 3

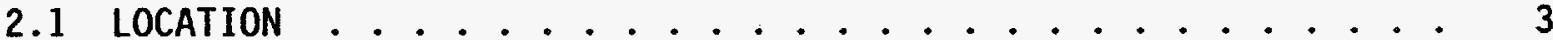

2.2 HISTORY OF OPERATION ................ . . . 3

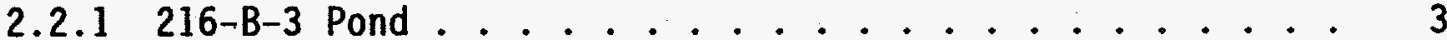

2.2 .2 216-B-3A and 216-B-3B Ponds .......... 7

$2.2 .3216-B-3 C$ Pond . . . . . . . . . . . 7

$2.3216-B-3 C$ POND WASTEWATER SOURCES ........... 9

2.3.1 242-A Steam Condensate and Cooling Water....... 9

2.3.2 241-A Tank Farm Cooling Water . . . . . . . . 12

2.3.3 244-AR Vault Cooling Water........... 13

2.3.4 B Plant Wastewater ............ 13

2.3.5 PUREX Chemical Sewer and Steam Condensate ...... 15

2.3.6 283-E Water Treatment Facility . . . . . . . . . 17

2.3.7 284-E Powerhouse . . . . . . . . . . . . 18

3.0 EFFLUENT CHARACTERISTICS . . . . . . . . . . . . . . . 19

3.1 DISCHARGE VOLUMES AND FLOW RATES ............ 19

3.2 EFFLUENT CHEMICAL CONSTITUENTS . . . . . . . . . . 22

4.0 SITE DESCRIPTION . . . . . . . . . . . . . . . 23

4.1 REGIONAL AND 200 EAST AREA GEOLOGY ........... 23

4.1.1 Regional . . . . . . . . . . . . . 23

4.1 .2200 Areas . . . . . . . . . . 26

4.2 GEOMORPHOLOGY AND STRATIGRAPHY OF THE 216-B-3 POND . . . . . 26

4.2.1 Geomorphology ............... 26

4.2.2 Stratigraphy .............. 26

4.3 REGIONAL AND 200 EAST AREA HYDROGEOLOGY . . . . . . . . 33

4.3.1 Regional . . . . . . . . . . . 33

4.3.2 200 East Area/Disposal Site Hydrology ........ 35

4.4 GROUND WATER QUALITY ............... . . 38

4.4.1 216-B-3 Pond System and Adjacent Disposal Facilities . . 38

4.4.2 B Pond RCRA Ground Water Monitoring Program . . . . . . 49

4.4.3 200 Areas Contaminant PTumes . . . . . . . . . 49

5.0 MODELING OF THE GROUND WATER SYSTEM ............. 63

5.1 CONCEPTUAL MODEL ................ 63

5.2 COMPUTER CODE .................. 66

5.3 MATHEMATICAL MODEL .............. . . 66

5.4 MODEL RESULTS .................. . . . 68

\section{DISCLAIMER}

This report was prepared as an account of work sponsored by an agency of the United States Government. Neither the United States Government nor any agency thereof, nor any of their employees, makes any warranty, express or implied, or assumes any legal liability or responsibility for the accuracy, completeness, or usefulness of any information, apparatus, product, or process disclosed, or represents that its use would not infringe privately owned rights. Reference herein to any specific commercial product, process, or service by trade name, trademark, manufacturer, or otherwise does not necessarily constitute or imply its endorsement, recommendation, or favoring by the United States Government or any agency thereof. The views and opinions of authors expressed herein do not necessarily state or reflect those of the United States Government or any agency thereof. 
WHC-EP-0813

\section{CONTENTS (cont.)}

6.0 IMPACT ASSESSMENT ......................... . . . . 73

6.1 HYDROLOGIC IMPACTS ..................... 73

6.2 CONTAMINANT IMPACTS . . . . . . . . . . . . . . . . . 73

6.3 MONITORING WELL NETWORK ADEQUACY . . . . . . . . . . . . . . 73

6.3.1 Ground Water Monitoring Well Placement . . . . . . . . . 73

6.3.2 Need for Additional Wells .............. 75

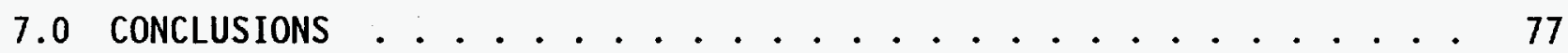

8.0 REFERENCES ................................... 79 
WHC-EP-0813

\section{LIST OF FIGURES}

1 Location Map for the 216-B-3 Pond . . . . . . . . . . . . . 4

2 Map Showing Main Features of the 216-B-3 Pond System . . . . . . 5

3 Plan View Sketch of the 216-B-3C Pond ............ 8

4 Current Flow Routes to the 216-B-3 Expansion Pond . . . . . . . 10

5 Location of the 216-E-28A Pipeline Feed to the 216-B-3C Pond. . . . 11

6 Discharge Volume to the B Pond System . . . . . . . . . . 21

7 Geologic Location Map for the Hanford Site and the Pasco Basin . . 24

8 Structural Contour. Map On the Top of Basalt for the 200 Areas . . . 25

9 Structural Contour Map On the Top of Basalt for the 200 East Area and the B Pond System ................ 27

10 Stratigraphic Nomenclature for the Pasco Basin . . . . . . . . 28

11 Well Location and Cross Section Map for the B Pond . . . . . . . . . 29

12 Cross Section A-A' Across the 216-B-3 Pond System, Indicating Hydrostratigraphic Units with Representative Properties . . . . . . 31

13 Cross Section B-B' Across the 216-B-3 Pond System, Indicating Hydrostratigraphic Units with Representative Properties . . . . . . 32

14 Location of Surface Water Bodies on the Hanford Site . . . . . . . 34

15200 Areas Water Table Map . . . . . . . . . . . . . 36

16 Specific Conductivity Map for the 200 East Area . . . . . . . . 40

17 Concentration Plot for Tritium at the 216-A-37-1 Crib Wells . . . . 41

18 Concentration-History Plot of Tritium . . . . . . . . . . 42

19 Rate of Change for Tritium in Selected Wells, 200 East Area . . . 43

20 216-A-45 cribs ........................ 44

21 Concentration-History Plot for Iodine-129 at Well 2-E17-13 . . . 46

22 Well Locations at the $216-B-62$ Crib . . . . . . . . . . . 47

23 Concentration-History Plot for Tritium at 216-B-62 Crib . . . . . 48

24 Ground Water Flow Paths .................. 51 


\section{LIST OF FIGURES (cont.)}

25 Arsenic Distribution in the Uppermost Aquifer Beneath the 200 Areas (Filtered Analyses) . . . . . . . . . . . .

26 Nitrate Distribution in the Uppermost Aquifer Beneath the

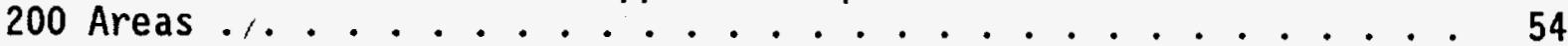

27 Tritium Distribution in the Uppermost Aquifer Beneath the 200 Areas .....................

28 Gross Beta Distribution in the Uppermost Aquifer Beneath the 200 Areas ................. 57

29 Technetium-99 Distribution in the Uppermost Aquifer Beneath the 200 Areas .................. 58

30 Iodine-129 Distribution in the Uppermost Aquifer Beneath the 200 Areas ................. . . 60

31 Gross Alpha Distribution in the Uppermost Aquifer Beneath the 200 Areas ....................

32 Diagrammatic Sketch of Potential Remobilization Mechanism of Existing Contaminants by the Continued Disposal of Clean

33 Model Domain of the 216-B-3 Pond System . . . . . . . . . . . 65

34 Simulated Water Table Map (October 1997) . . . . . . . . . . . 69

35 Difference Between Simulated 1992 and 1997 Water Table Elevations . . 70 
WHC-EP-0813

\section{LIST OF TABLES}

1 Historical Discharge to the B Pond System . . . . . . . . 20

2 Projected Flow Rate to the 216-B-3C Expansion Pond . . . . . . . 22

3 Wells With Constituents Exceeding Drinking Water Standards

by Quarter, Fiscal Year $1993 \ldots . . . . . . . . . .50$

4 Effluent Disposal to the 216-B-3 Pond System . . . . . . . 67

5 Construction Summary--216-B-3 Pond Trench Ground Water

Monitoring Network ................ 74 


\section{LIST OF TERMS}

3A Pond.

3B Pond

$3 C$ Pond

B Plant

CFR

CRBG

DOE

DWS

Ecology

EPA

FY

GIA

PUREX

RCRA

RL

Tri-Party

Agreement VAM3DCG

WAC

WESF

WHC

WWQS
216-B-3A Pond

216-B-3B Pond

216-B-3C Pond

221-B P1ant

Code of Federal Regulations

Columbia River Basalt Group

U.S. Department of Energy

drinking water standard

Washington State Department of Ecology

U.S. Environmental Protection Agency

fiscal year

ground water impact assessment

Plutonium-Uranium Extraction (Facility)

Resource Conservation and Recovery Act of 1976

Richland Operations office

Hanford Federal Facility Agreement and Consent Order

Variably Saturated Analysis Model in $\underline{3}$-Dimensions with Preconditioned Conjugate Gradient Matrix Solver

Washington Administrative Code

Waste Encapsulation and Storage Facility

Westinghouse Hanford Company

Washington Water Quality Standard 
WHC-EP-0813

\section{GROUND WATER IMPACT ASSESSMENT REPORT FOR THE 216-B-3 POND SYSTEM}

\subsection{INTRODUCTION}

Ground water impact assessments (GIA) are required for a number of liquid effluent receiving sites according to the Hanford Federal Facility Agreement and Consent Order (Tri-Party Agreement) Milestones M-17-00A and M-17-00B, as agreed upon by the U.S. Department of Energy (DOE) (Ecology et a1. 1992). This report assesses the impacts to ground water from the disposal of effluent to the 216-B-3 Pond system in the 200 East Area.

\subsection{BACKGROUND}

In response to public comments on the original Tri-Party Agreement, and at the request of the signatories on the Tri-Party Agreement, the DOE, Richland Operations office (RL) conducted a study to assess the impact of liquid effluents discharged to the ground at the Hanford Site (WHC 1990a, 1990e). The U.S. Environmental Protection Agency (EPA) and the Washington State Department of Ecology (Ecology) expressed concerns regarding uncertainties in the evaluations made by RL. Foremost among these concerns were the lack of site-specific data, the need to consider interactions with adjacent liquid discharge facilities, and the need for more rigorous models of contaminant transport. As a result of these concerns, RL, Ecology, and EPA (the three parties) created a series of Tri-Party Agreement Milestones, including $M-17-00 A, M-17-00 B, M-17-13$, and $M-17-13 A$, which pertain to GIAs.

Tri-Party Agreement Milestones M-17-00A and M-17-00B require impact assessments for Phase I and II waste streams. Phase I and II waste streams are defined in Stordeur and Flyckt (1988). Tri-Party Agreement Milestone M-17-13 required the development of a methodology for assessing the impact of liquid effluent discharge on ground water, which resulted in the document A Methodology for Assessing Impacts to Groundwater from Disposal of Liquid Effluent to the Soil at the Hanford Site (WHC 1991). Thirty days after regulatory approval of the methodology document, as required by Tri-Party Agreement Milestone M-17-13A, a schedule for performing the assessments at 13 receiving sites was completed.

\subsection{METHODOLOGY}

The aforementioned methodology document (WHC 1991) was followed in preparing this GIA report. WHC (1991) included the categorization of each of the 13 receiving sites into 1 of 3 levels based on the amount of effort needed to perform the assessment. A level 1 receiving site GIA relies on available information. A GIA of a level 2 receiving site may require nonintrusive field work to verify the extent of existing contamination. A level 3 site may require intrusive field work. The assessment may be raised to a level 2 or 3 assessment if it is discovered that existing information is inadequate through 
the course of performing a level 1 impact assessment. The B Pond system is a level 1 receiving site for which the following tasks were identified in WHC (1991).

- Prepare and present plan describing how the GIA wi1l be conducted

- Characterize the liquid effluent stream

- Evaluate the site-specific hydrogeology

- Develop a site conceptual model

- Assess the hydrologic impact of the liquid effluent stream

- Assess the contaminant impact of the 1iquid effluent stream

- Evaluate the adequacy of the existing monitoring well network

- Prepare a written report of the resuits.

The tasks required for level 2 and 3 receiving sites are similar to those outlined above, but also include field work-related activities. The 216-B-3 Pond was categorized as a level 1 receiving site, primarily on the basis of effluent characteristics (WHC 1990C).

Several key assumptions inherent to all GIAs are explained in WHC (1991) and warrant summarizing here. For this GIA, the following assumptions are relevant.

- The expected level of impact from use of the receiving site determines how well the chemistry, geology, and hydrology need to be understood.

- Modeling sophistication is tailored to available information and the expected level of impact of the receiving site.

- Historical data are fully useable.

The primary focus for this assessment, as identified in the assessment plan (WHC 1994), is an evaluation of hydraulic impacts and interactions. Existing chemical and hydrogeologic data were judged to be adequate for purposes of this level 1 assessment. 
WHC-EP-0813

\subsection{6-B-3 POND DESCRIPTION}

\subsection{LOCATION}

The 216-B-3 Pond system, located at the Hanford Site in southeastern Washington State (Figure 1), consists of a main pond and three expansion ponds for wastewater disposal as well as several ditches leading to the ponds (Figure 2). The main pond is located east of the 200 East Area, diked on the eastern margin, and currently covers approximately 14.2 ha ( 35 acres), with a maximum depth of about $6.1 \mathrm{~m}(20 \mathrm{ft}$ ) (see Figure 2). The 216-B-3 Pond began receiving liquid effluent in 1945. Three expansion ponds (216-B-3A [3A], 216-B-3B [3B], and 216-B-3C [3C]) were placed into service in 1983, 1984, and 1985, respectively. The $3 A$ and $3 B$ Ponds are about 4.5 ha (11 acres) in size, and the $3 \mathrm{C}$ Pond is approximately 16.6 ha ( 41 acres). The main lobe has been recently backfilled as part of interim stabilization procedures for the 200-BP-11 operable unit Resource Conservation and Recovery Act of 1976 (RCRA) corrective action. The $3 C$ Expansion Pond is the only pond now receiving effluent. Water discharged to this pond infiltrates into the ground and recharges the underlying aquifer. During 1993, the volume of effluent discharged to the $B$ Pond system averaged approximately $13,000 \mathrm{~L} / \mathrm{min}$ (3,400 $\mathrm{gal} / \mathrm{min})$ or $19 \mathrm{milli}$ ion L/day ( $5 \mathrm{million} \mathrm{gal} / \mathrm{day}$ ).

The 216-B-3 Ponds and the 216-B-3-3 Ditch are scheduled to be closed as part of an integrated effort with RCRA past-practice activities at the 200-BP-11 operable unit. The work plan for this integrated effort currently is planned to be completed in fiscal year (FY) 1995 (DOE-RL 1994a).

The locations of the $3 A, 3 B$, and $3 C$ Ponds, the 216-B-3 Pond, and the 216-B-3-3 Ditch are shown in Figure 2. Figure 2 also shows nearby waste management units: the 216-E-28 Contingency Pond and the 216-B-3-1, 216-B-3-2, and 216-A-29 Ditches. All of the previously mentioned ponds and ditches are part of the 200-BP-11 operable unit, with the exception of the 216-A-29 Ditch. The 216-A-29 Ditch is a separate treatment, storage, and/or disposal unit that is currently part of the 200-P0-05 operable unit. The closure/ postclosure plan for the 216-A-29 Ditch currently is scheduled to be submitted to Ecology and the EPA in May 1996 in accordance with the Tri-Party Agreement (Ecology et a1. 1992).

\subsection{HISTORY OF OPERATION}

\subsubsection{6-B-3 Pond}

The 216-B-3 (Main) Pond, in service since 1945, is located in a natural topographic depression. From 1945 through 1964, wastewater was discharged to the 216-B-3 Pond via the unl ined, earthen 216-B-3-1 Ditch. The ditch widened towards the inlet to the pond, and as a result, covered a fairly large, swampy surface area that terminated in a small, shallow pond (216-B-3 Pond)

(DOE-RL 1994a). 


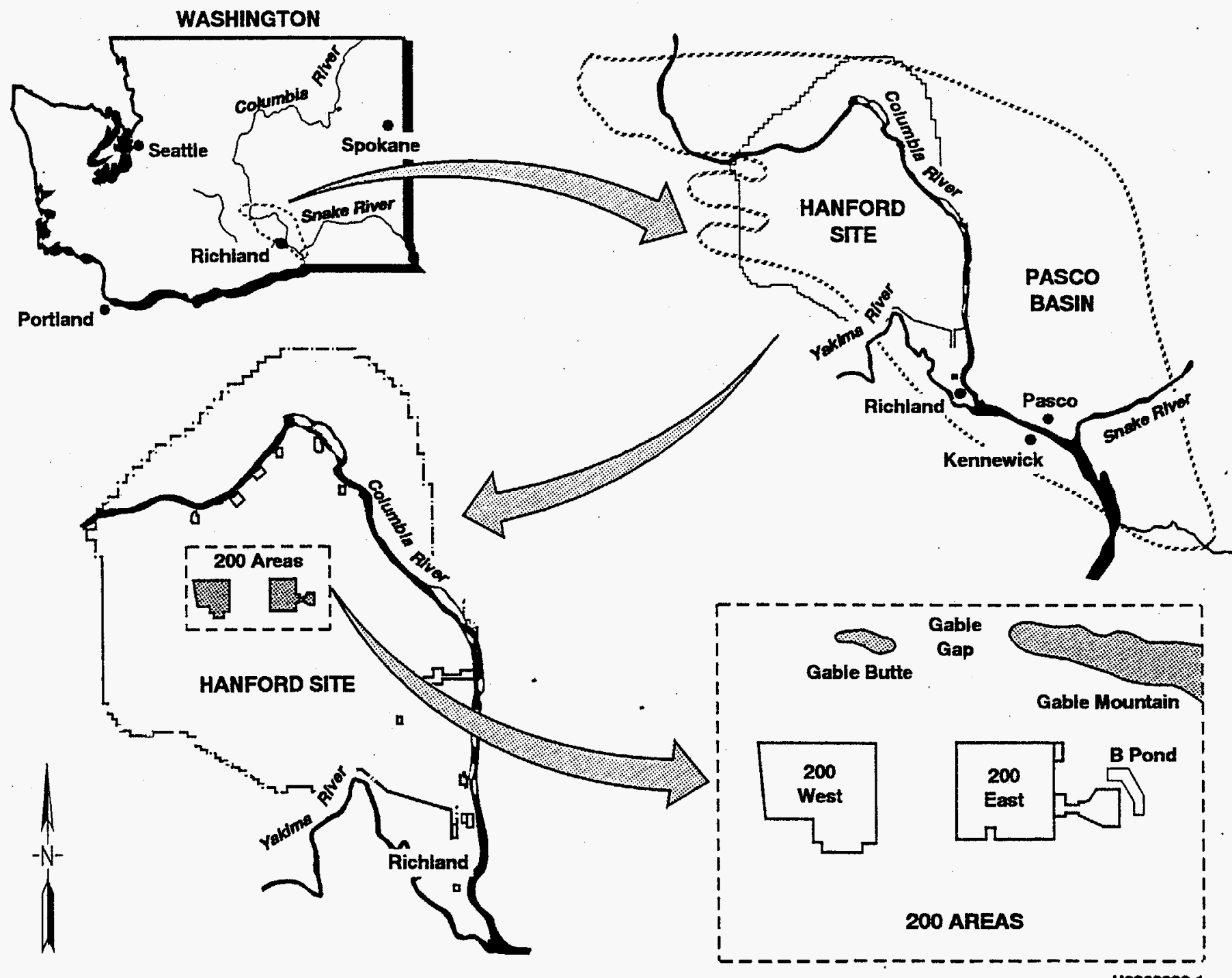

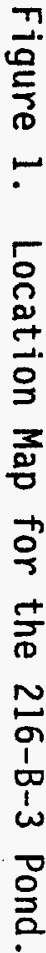




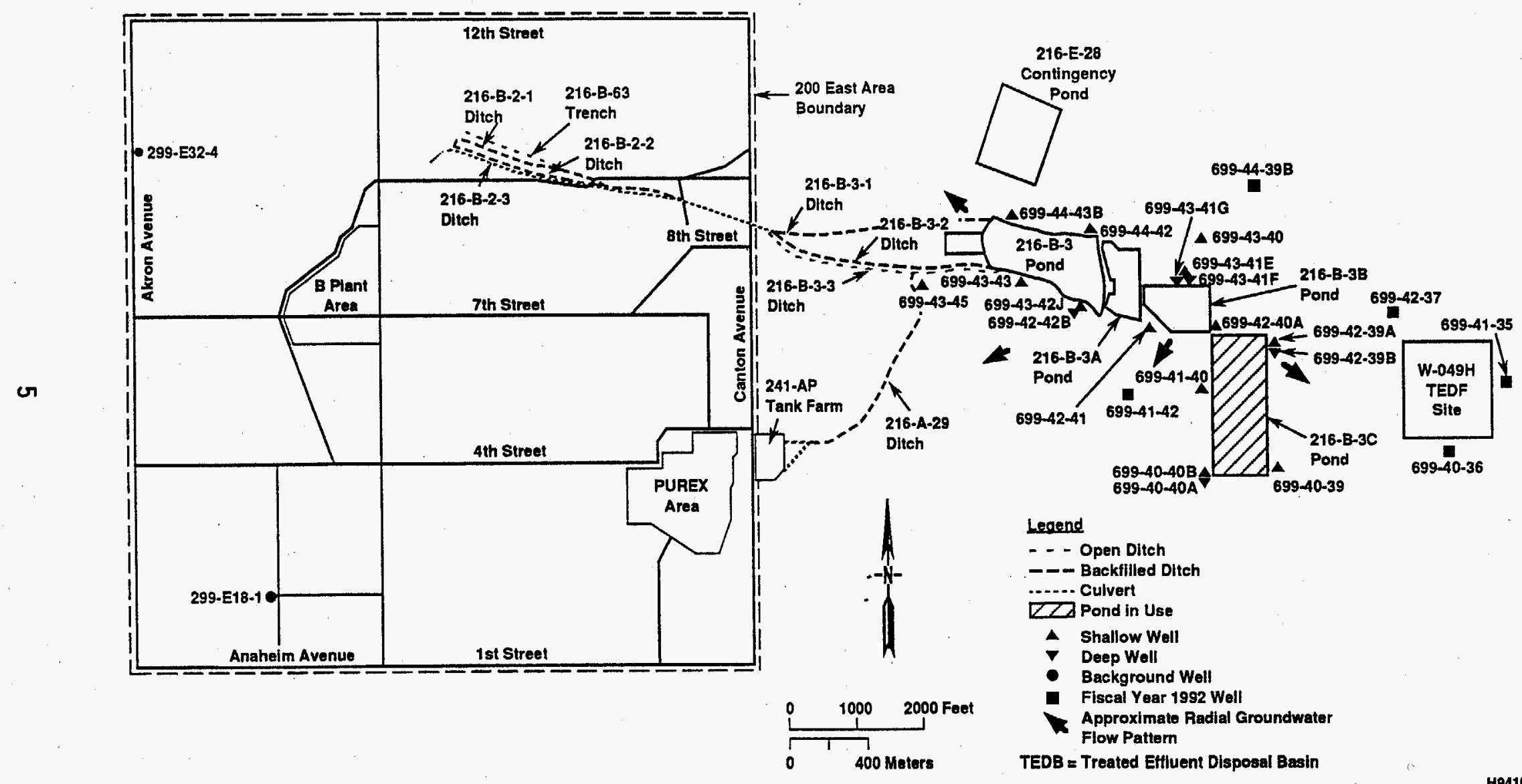

곰.

$\Xi$

离

$\circ$

节

$N$

o

क

$\omega$

$\stackrel{0}{\circ}$

年 
In 1955, the 216-A-29 Ditch was placed in service to receive PlutoniumUranium Extraction (PUREX) Facility chemical sewer wastewater. In the past, the 216-A-29 Ditch discharged directly into the 216-B-3-1 Ditch. The 216-B-3-1 Ditch was decommissioned and backfilled with soil in 1964 after an accidental release of mixed fission products from the PUREX Facility. This release was discharged to the 216-B-3-1 Ditch via the PUREX Facility cooling water line rather than the 216-A-29 Ditch (DOE-RL 1994a).

The unlined, earthen 216-B-3-2 Ditch was excavated in 1964 to replace the 216-B-3-1 Ditch. The 216-A-29 Ditch discharged into the 216-B-3-2 Ditch approximately $305 \mathrm{~m}(1,000 \mathrm{ft})$ west of the 216-B-3 Pond. The 216-B-3-2 Ditch was decommissioned and backfilled with soil in 1970 after an accidental release of strontium-90 from 221-B P1ant (B P1ant). As a result of this release, the contaminated 216-B-3 Pond bank soil was dozed into the pond, and the north, south, and west shorelines were diked with $0.9 \mathrm{~m}(3 \mathrm{ft})$ of sand and gravel (DOE-RL 1994a).

The unlined, earthen 216-B-3-3 Ditch was excavated in 1970 to replace the 216-B-3-2 Ditch, and the 216-A-29 Ditch was routed to its present discharge point in the 216-B-3-3 Ditch approximately $457 \mathrm{~m}(1,500 \mathrm{ft})$ west of the inlet to the 216-B-3 Pond. The 216-B-3-3 Ditch is approximately $1,128 \mathrm{~m}(3,700 \mathrm{ft})$ long, $9 \mathrm{~m} \mathrm{(30} \mathrm{ft)} \mathrm{wide} \mathrm{at} \mathrm{ground} \mathrm{level,} 1.8 \mathrm{~m}(6 \mathrm{ft})$ wide at the bottom, and 1.2 to $2.4 \mathrm{~m} \mathrm{(4} \mathrm{to} 8 \mathrm{ft}$ ) deep. A fiberglass-reinforced polyester flume and flowmeter were installed downstream of the 216-A-29 and 216-B-3-3 Ditches confluence. Flow rates are recorded on a strip chart and flow recordings are taken daily (DOE-RL 1994a).

In December 1970, the dike along the eastern shore of the 216-B-3 Pond failed, and in 1971, major construction was initiated to extend and raise the earthen dike. Construction materials were obtained from a borrow pit located near the pond, and were laid in 20-cm- (8-in.- [or less]) thick layers. The dike now is approximately $421(1,380 \mathrm{ft})$ long and $13 \mathrm{~m}$ (42 ft) wide near the top, with basalt riprap added for erosion protection (DOE-RL 1994a).

An area of approximately 1.7 ha (4.1 acres) immediately west of the 216-B-3 Pond (see Figure 2) was diked during the 1970's to provide an overflow area for the 216-B-3 Pond. The overflow area was decommissioned and backfilled in 1985 (DOE-RL 1994a).

The main pond formerly covered approximately 14.2 ha (35 acres). Historical records indicate that the surface area of the pond varied from 8 to 19 ha (19 to 46 acres) during its operation (DOE-RL 1994a).

Most of the 200 East Area wastewater was discharged to both B Pond and Gable Mountain Pond (216-A-25 Pond) until 1987, when decommissioning of the Gable Mountain Pond was completed. Most of the 200 East Area wastewater, exclusive of the PUREX Facility chemical sewer and a few other facilities, was routed to the cooling water line that runs parallel to the 200 East Area perimeter fence. From the cooling water line, the wastewater could have been diverted to either the 216-B-3 Pond or Gable Mountain Pond. Since the decommissioning of Gable Mountain Pond, all wastewater was discharged to the 216-B-3 Pond until stabilization activities were performed (DOE-RL 1994a). 


\subsubsection{6-B-3A and 216-B-3B Ponds}

The $3 A$ and $3 B$ Ponds were constructed to receive increased discharges that would result from restart of the PUREX Facility. The ponds were constructed using a cut-and-fill construction method over a 9-ha (22-acre) surface area (4 ha [11 acres] each). Polyethylene plastic (8-mil) was placed along the slope of the pond banks and was covered with approximately $8 \mathrm{~cm}(3 \mathrm{in}$.$) of pit$ run gravel. The plastic was extended approximately $0.9 \mathrm{~m}(3 \mathrm{ft})$ out onto the pond bottom and $0.6 \mathrm{~m}(2 \mathrm{ft}$ ) back from the top of the dike (DOE-RL 1994a).

The 3A Pond was placed into service in October 1983. The pond was operated until January 1984 when the dike between the $3 A$ and $3 B$ Ponds failed at the connecting spillway. All discharge caused by the dike failure was contained in the 3B Pond, which had remained unused until this time. The dike failure is suspected to be the result of water seeping through the dike, under the erosion-control fabric lining the spillway (DOE-RL 1994a).

In response to this incident, flow to the 216-B-3 Pond was reduced and the $3 A$ and $3 B$ Ponds were isolated. A trench, oriented north-south and approximately $183 \mathrm{~m}$ (600 ft) long, $9 \mathrm{~m}(30 \mathrm{ft})$ wide, and $1.5 \mathrm{~m}(5 \mathrm{ft})$ deep, was excavated into a permeable sand and gravel layer beneath the $3 \mathrm{~A}$ Pond bottom to provide an area of increased infiltration. Discharge to the $3 \mathrm{~A}$ Pond was resumed but at a reduced rate to contain flow and infiltration to the newly constructed trench (DOE-RL 1994a). The 3A Pond is no longer in use.

The debris from the dike failure was removed from the $3 \mathrm{~B}$ Pond and $\mathrm{a}$ series of trenches were excavated in the $3 B$ Pond bottom to increase the infiltration rate. The excavated material was placed along the shores of the 216-B-3 Pond as diking (DOE-RL 1994a).

The $3 A$ and $3 B$ Ponds were fully operational by June 1984 . The $3 B$ Pond was taken out of service in May 1985, and up to $2 \mathrm{~m}(7 \mathrm{ft})$ of material was excavated from the pond bottom to a depth below the bottom of the trenches. The excavated material was placed as diking on the north shore of the 216-B-3 Pond. The pond has not been used since it was taken out of service in May 1985 (DOE-RL 1994a).

\subsubsection{6-B-3C Pond}

The 216-B-3C Pond was constructed to accommodate increased flow that resulted from decommissioning of Gable Mountain Pond. The $3 \mathrm{C}$ Pond was constructed by excavating $1.8 \mathrm{~m}(6 \mathrm{ft})$ of soil over a 17-ha (41-acre) surface area. Eight parallel north-south trenches, approximately 2 to $4 \mathrm{~m}$ (8 to $14 \mathrm{ft}$ ) wide and $1.2 \mathrm{~m}(4 \mathrm{ft})$ deep, were constructed in the pond bottom to increase infiltration. An east-west trench in the $3 \mathrm{C}$ Pond bottom connects the 216-B-354 outfall with the eight north-south trenches (Figure 3). The excavated material was placed in a spoil mound along the east and part of the north and south sides of the $3 C$ Pond. The slopes of the pond were stabilized with 3 in. of 2.54- to $15-\mathrm{cm}$ (1- to 6-in.-) size gravel. A gravel maintenance road was constructed along the edge of the $3 C$ Pond (DOE-RL 1994a). 
Figure 3. Plan View Sketch of the 216-B-3C Pond.

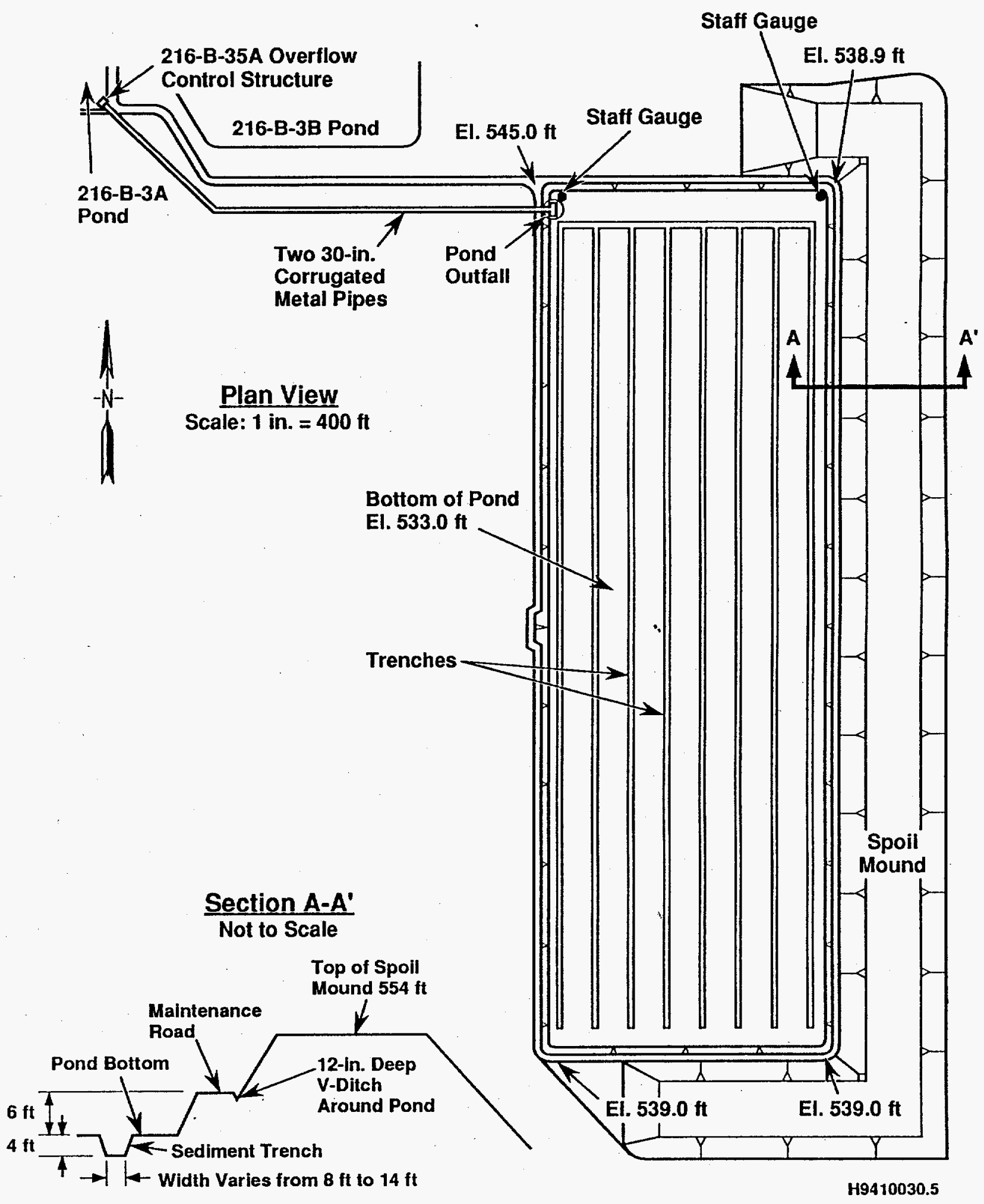




\subsection{6-B-3C POND WASTEWATER SOURCES}

This section describes the procesises that generate the waste streams discharged to the $3 C$ Expansion Pond. The information in this section was obtained from DOE-RL (1994a). The 3C Expansion Pond receives wastewater from the following sources (Figure 4):

- 242-A steam condensate

- 242-A cooling water.

- 241-A Tank Farm cooling water

- 244-AR Vault cooling water

- B Plant cooling water (B Plant chemical sewer)

- PUREX chemical sewer

- PUREX steam condensate

- 283-E Water Treatment Facility

- 284-E Powerhouse steam.

Since February 1994, discharge to the $3 C$ Expansion Pond has been via a bypass pipeline that allows for direct discharge (Figure 5).

\subsubsection{2-A Steam Condensate and Cooling Water}

The 242-A Evaporator is used for the concentration of low-level radioactive solutions at the Hanford Site. Feed is supplied to the evaporator from the evaporator feed Tank 241-102-AW. Radioactive 1iquid waste that has been identified for concentration is transferred to Fank 241-102-AW. Feed is supplied from Tank 241-102-AW in the range of 341 to $530 \mathrm{~L} / \mathrm{min}$ (90 to $140 \mathrm{gal} / \mathrm{min}$ ).

Concentration of the feed stream results in the production of two liquid process streams. The outlet streams consist of a process condensate stream, which is condensed water vapor evaporated from the feed that is routed to the Effluent Treatment Facility, and a slurry stream containing concentrated feed that is routed to double-shell tanks. Additionally, the process condensate stream contains steam condensate from the vacuum jets used to maintain the evaporator under vacuum.

Steam is used to heat the feed solution contained in a reboiler (E-A-1). Because the reboiler is essentially a large heat exchanger, steam never is in contact with the process material. The steam is condensed, routed to a flow measurement tank, and monitored for radiation levels while flowing to a retention basin. If a high radiation level is detected, the stream automatically is diverted from the retention basin to Tank 241-102-AW. The steam condensate in the retention basin is sampled to determine total radiation levels (alpha and beta) before being sent to the 216-B-3 Pond system.

The cooling water used to condense the process condensate is routed through a radiation monitor on its way to the 216-B-3 Pond system. Because of the low potential for radionuclide contamination, there is no automatic diversion capability on this stream. Should a small leak occur in the tube bundle that separates the cooling water from the process condensate, the large 
Figure 4. Current Flow Routes to the 216-B-3 Expansion Pond.

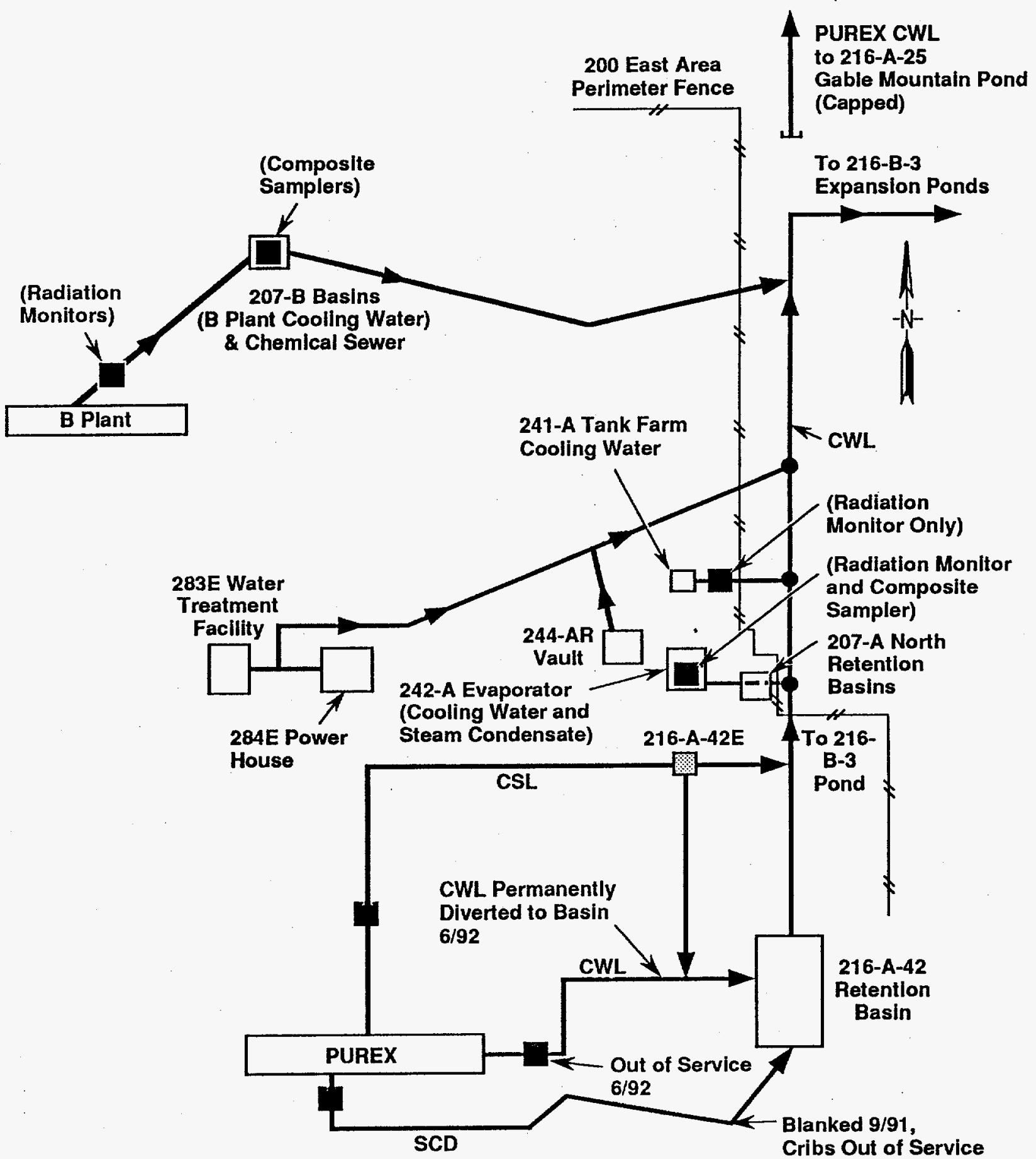

Proportional Samplers/

Radiation Monitors

Diversion Point
CWL $=$ Cooling Water Line

CSL $=$ Chemical Sewer Line

SCD $=$ Steam Condensate 


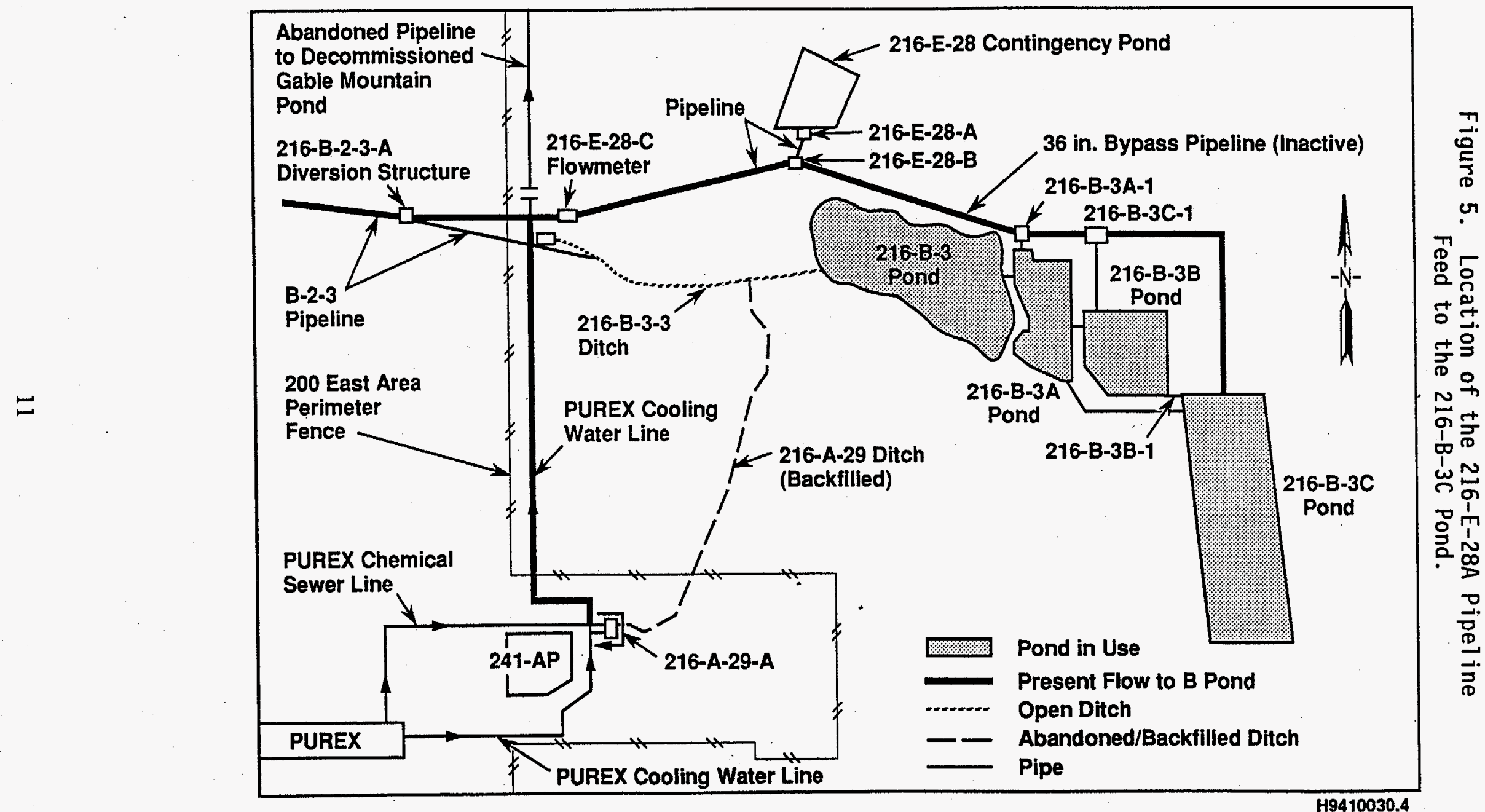


pressure differential between the two streams will prevent the process condensate from contaminating the cooling water. This is because the cooling water is maintained under $30 \mathrm{lb}$ of positive pressure, while the process condensate is maintained under a vacuum. The presence of contaminated cooling water would indicate a massive failure of the condenser, and the evaporator would be shut down.

Additional sources of nondangerous liquid effluent to the $3 C$ Expansion Pond from the 242-A Evaporator are attributed to steam condensate from the standby steam turbine exhaust fan, building heating and ventilation steam condensate, building air wash water, air compressor system cooling water, and steam condensate from compressed air dryers.

\subsubsection{1-A Tank Farm Cooling Water}

The 241-A Tank Farm aging waste ventilation system complex is used to perform the following activities:

- Maintain vacuums on the high-level radioactive waste storage tanks (241-AY and 241-AZ Tank Farms)

- Condense radioactive vapors generated from these tanks

- Filter the tank exhaust before discharging to the environment.

High-level radioactive waste storage tanks are self-boiling, which results in the generation of large quantities of condensible, radioactive vapors. Vapors generated from the boiling tanks are liquified in condensers $E-413, E-414$, and E-415, using raw water as a cooling medium. Condensate is routed to a condensate holdup tank (241-A-417) and sent back to a self-boiling tank in the 241-AY or 241-AZ Tank Farm to maintain the liquid level. The cooling water then is routed to the $3 C$ Expansion Pond after passing through a proportional sampler and monitor.

An emergency cooling system (closed 10op) exists to provide the necessary cooling water to the surface condensers if the raw water supply from the 241-C Tank Farm fails or the radiation level in the exit cooling water stream exceeds a preset level on the radiation monitor. The emergency cooling system consists of a warm water sump, a cooling tower, a cold water sump, and a deep we 11 pump.

The warm water sump receives cooling water after it has cooled the surface condensers. The warm water is routed to the cooling tower that cools water by using the cooling effects associated with partial evaporation of warm water (latent heat of evaporation). The remaining cooled water is sent to the cold water sump to be reused as the cooling water supply stream for the surface condensers. The deep well pump provides makeup water to the cold water sump to maintain the sump volume because part of the water is lost due to evaporation occurring in the cooling tower.

Should the cold water sump overflow, liquid would be routed to the warm water sump. If the warm water sump over flows, liquid would be routed to the 
WHC-EP-0813

proportional sampler and monitored with the normal cooling water supply before being sent to the $3 C$ Expansion Pond.

\subsubsection{4-AR Vault Cooling Water}

The 244-AR Vault began operation in 1969 and continued to operate through 1978. The 244-AR Vault facility was originally used to prepare radioactive waste for transfer to the B Plant for removal of cesium and strontium. The radioactive waste was generated by other Hanford Site activities and was temporarily stored in underground storage tanks before being transferred to the 244-AR Vault tanks. Currently, the 244-AR Vault is on standby with no radioactive waste operations in progress. However, to maintain the facility for future use, some operational requirements are being met. Cooling water is used to cool the compressors that supply instrument air to the facility. Additionally, cooling water and heating steam are also supplied to the ventilation system to control the temperature of the inlet air to the facility. Discharges from these systems comprise the facility's current (standby mode) waste stream. At present, no record sampling or radiation monitoring instruments are associated with this waste stream; the facility is inactive and the waste stream is discharged from a closed system that has minimal potential for contamination. Since FY 1985, upgrades have been made to 244-AR Vault systems to reduce potential radioactive discharges for facility operation. For a more detailed description see DOE-RL (1994a).

\subsubsection{B Plant Wastewater}

The B Plant has had a number of missions since its construction in 1943. Its first mission was the recovery of plutonium using a bismuth phosphate chemical separation process. The process was carried out from April 1945 to October 1952. The B Plant was shut down after the Reduction Oxidation Plant and the PUREX Facility came online. The B Plant was modified to begin its second mission in 1968, consisting of the recovery, purification, and encapsulation of cesium and strontium. Currently the encapsulated cesium and strontium is stored at the B Plant.

Discharge to the 216-B-3 Pond system from B Plant originated from two sources: B Plant cooling water [including the Waste Encapsulation and Storage Facility [WESF ${ }^{4}$ ] and B Plant chemical sewer).

The $B$ Plant cooling water is the source of some minor radionuclides and potential chemical contaminants in the 216-B-3 Pond system. B Plant cooling water also includes cooling water discharged from heat exchangers at the WESF. The cooling water discharged from the WESF does not come into direct contact with the stored cesium and strontium capsules, but is circulated through heat exchangers that cool the pool cell water.

Pool cell water, which is used to cool the cesium and strontium capsules, normally is disposed by an alternate method. Currently, B Plant cooling water

${ }^{4}$ The Waste Encapsulation Storage Facility cooling water mixes with the B Plant cooling water (from 1974 to present). 
and the $B$ Plant chemical sewer are discharged to the $3 C$ Expansion Pond. The average flow rate of $B$ Plant cooling water is about 5,678 to $6,814 \mathrm{~L} / \mathrm{min}$ $(1,500$ to $1,800 \mathrm{gal} / \mathrm{min})$.

Starting in 1945, the B Plant chemical sewer was discharged to the 216-B-3 (Main) Pond. The chemical sewer was diverted to the 216-B-63 Trench on May 7, 1970. In February 1992, the chemical sewer was combined with the B Plant cooling water and discharged to the $3 C$ Expansion Pond.

The major contributors to the chemical sewer are the 2902-B High Tank (which contains potable water), cooling water from B Plant and WESF air compressor aftercoolers, and some 221-B steam condensate. The chemical sewer also receives minor contributions from air conditioning units and space heaters (radiators), and has an average flow rate of approximately $568 \mathrm{~L} / \mathrm{min}$ (150 gal/min).

According to B Plant emergency procedures, if B Plant cooling water becomes radioactively contaminated, it would be diverted away from the 3C Expansion Pond to the 216-B-59 Retention Basin.

The B Plant cooling water comes from the 200 East Area raw water 1 ine, which is derived from the Columbia River, and is passed through cooling coils in the plant process tanks and vessels. The cooling water is discharged from the plant as two separate streams. Each stream is monitored continuously for compliance with radiological standards.

The first stream is collected in a $61-\mathrm{cm}(24-\mathrm{in}:)$ header and receives discharge from those processing vessels that are considered to have a low potential for possible contact with radioactive solutions. Should one of these vessels leak, the effect on the environment would be minimal. Feed for this stream includes several processing condensers, B Plant steam condensate condenser, effluent from the 212-B cask station, and all cooling water from the 225-B encapsulation facility pool cell heat exchangers.

The second stream receives feed primarily from cooling coils on process tanks in the B Plant. This second stream is continuously monitored for radiation (beta, gamma) activity. The stream is diverted automatically to the 216-B-59 Retention Basin if found to exceed radiological control 1 imits. If the second stream meets requirements for discharge to the environment, it is combined with the first stream (WHC-CM-7-5).

The combined stream is sampled continuously on a flow-proportional basis before entering one of two 2,138,751-L (565,000-gal) basins (207-B Facility), and the aliquot is deposited into a 19-L (5-gal) holding tank. The contents of the holding tank are agitated weekly and a sufficient volume of sample is withdrawn to provide weekly analytical determinations for process control ( $\mathrm{pH}$, total beta, total alpha, and individual isotopes, if necessary).

A separate volume of sample also is withdrawn weekly and samples collected are combined for a monthly composite. Analyses are performed by the onsite laboratory (222-S Laboratory). Reported results become the 'record' data for the combined stream. From the 207-B Facility, the water flows to the $3 C$ Expansion Pond (see Figure 4). Water exceeding requirements could be diverted to the 216-B-63 Trench or otherwise returned to the B Plant. 
2.3.4.1 B Plant Chemical Sewer Streams. In February 1992, the B P1ant chemical sewer was joined to the cooling water stream. The combined stream is discharged to the $3 C$ Expansion Pond. Before February 1992, the B Plant chemical sewer was discharged to the 216-B-3 Trench. The chemical sewer is monitored in the 211-BA neutralization facility for $\mathrm{pH}$, total beta, and total gamma. Sampling is performed using the B Plant cooling water sampling system. The 211-BA neutralization facility began operation in February 1992 . The facility can neutralize up to $757 \mathrm{~L} / \mathrm{min}(200 \mathrm{gal} / \mathrm{min})$ to a range between a $\mathrm{pH}$ of 5 and 9 . The facility was built to prevent $\mathrm{pH}$ discharges greater than 12.5 or less than 2 from reaching the environment.

The B Plant chemical sewer consists of the following:

- 221-B Drain system

- 271-B Drain system

- 211-B Tank storage area

- 217-B Demineralized water unit building drains

- 276-B Organic makeup building drains

- 225-B Encapsulation facility

- 212-B Cask station

- 2902-B High tank overflow drains

- 222-B Laboratory

- 224-B Facility

- 292-B Facility

- 900 tanks

- Five street and yard drains.

For a more detailed description of the above systems, see DÓE-RL (1994a).

\subsubsection{PUREX Chemical Sewer and Steam Condensate}

The PUREX Facility was used to process irradiated nuclear fuel. The supply of nuclear fuel was obtained from the 100 Area Fuel Basins, where it was stored after being discharged from the $N$ Reactor. Plutonium and uranium were the primary product materials recovered from the irradiated fuel.

The PUREX Facility began operation in January 1956 and operated until June 1972, when the facility was placed on standby. After plant and process upgrades, the facility was restarted in November 1983 and operated until 1991. It was transitioned from operational to standby mode in 1992 and is now being transitioned to shutdown mode. Once shut down, the facility will not be staffed and will produce no liquid effluent streams. The facility will remain in a deactivated state for several years until final decontamination and decommissioning.

Current discharges from the PUREX Facility to the $3 C$ Expansion Pond come from the chemical sewer. These discharges are limited by administrative controls. As of 1990, both the PUREX chemical sewer line and cooling water have been designated as nondangerous waste streams in accordance with the Hanford Site Stream-Specific Report, WHC-EP-0342, Addendums 2 and 20

(WHC 1990 c). The cooling water and steam condensate streams were shut down and diverted to the chemical sewer during the 1992 transition to standby. From 1956, when PUREX became operational, until transition to standby mode in 
1992, the steam condensate stream could be sent to the 3B Expansion Ponds after being diverted to the 216-A-42 Diversion Basin. The 216-A-42 Diversion Basin, a radiation diversion basin, was used to hold PUREX effluent streams while the water was verified as acceptable, based on radiation levels for release. The steam condensate stream normally was discharged to the 216-A-30 and the 216-A-37-2 Cribs.

Diversion of the chemical sewer to the 216-A-42 Diversion Basin occurs automatically when a high radionuclide content is detected or when an electrical failure occurs. These administrative controls were in effect before the construction of the 216-B-3 Expansion Ponds. The PUREX chemical sewer is continuously monitored for beta and gamma radiation. The chemical sewer discharge must be diverted manually to the 216-A-42 Diversion Basin when the $\mathrm{pH}$ is greater than or equal to 12.5 or less than or equal to 2.0 . A pH meter with settings of 5 and 10 is located 8 minutes travel time upstream of the diversion valve to allow an adequate margin of safety in meeting all requirements.

After a stream has been diverted to the 216-A-42 Diversion Basin, the basin is sampled to determine the $\mathrm{pH}$ and radionuclide content of the liquid. The $\mathrm{pH}$ of the basin contents is measured because the most probable dangerous waste constituent would be a corrosive material. Table A-3 lists recorded releases from the PUREX chemical sewer line. If sample analyses indicate the solution in the basin is out of range (with respect to dangerous waste characteristics and/or radioactivity), the following options exist.

- Send the material back to the PUREX Facility for reprocessing.

- Route the material to the Tank Farms via the PUREX Facility.

Liquid in the basin is pumped to the 216-B-3 Expansion Ponds via the bypass pipeline when the sample analysis indicates the material is within the proper specifications for disposal to the environment. Process knowledge and extensive sampling of the chemical sewer line, in accordance with the Washington Administrative Code (WAC) 173-303-090, "Dangerous Waste Regulations," form the basis for the proper specifications.

\subsubsection{PUREX Chemical Sewer. The chemical sewer stream was the most} probable source for discharge of a dangerous material. Between 1984 and 1992, numerous administrative controls and engineering barriers were implemented to prevent dangerous waste from being disposed to the chemical sewer and these barriers are still in use today.

The chemical sewer can receive liquid from the following sources:

- Heating and ventilation condensate

- Carrier water

- Vacuum pump seal water

- Pipe and operating gallery

- Miscellaneous floor drains

- Recovered nitric acid system (no longer a source)

- Aqueous makeup area

- 203-A (former) uranium storage area

- 211-A chemical storage area

- 618-1 flash tank 
- Distilled water systems

- 2901-A Tank overflow

- Sanitary pipe trench condensate.

For a more detailed description, see DOE-RL (1994a).

2.3.5.2 PUREX Steam Condensate. The steam condensate discharge primarily received cooling water and steam condensate discharges from most of the equipment that required heating during normal use in the PUREX Facility process. The steam condensate stream was shut down in June 1992. The cooling water or steam passed through a coil inside a piece of equipment. Unless there was a breach in the coil, the cooling water or steam never came into physical contact with radioactive or dangerous material; therefore, the steam condensate discharge usually was nonradioactive and did not contain dangerous waste.

Unless the steam condensate discharge stream was diverted to the 216-A-42. Diversion Basin because of high radiation or an electrical failure, the steam condensate discharge normally was discharged to the $216-A-30$ and the 216-A-37-2 Cribs. The steam condensate discharge is now being discharged to the $3 C$ Expansion Pond.

The steam condensate discharge consisted of steam condensate and water from the following sources:

- Concentrator coils

- Dissolver coils

- Quench water.

For a more detailed description, see DOE-RL (1994a).

\subsubsection{3-E Water Treatment Facility}

The 283-E Water Treatment Facility purifies and treats raw water and produces sanitary water for the 200 East Area. As mentioned previously, raw water is pumped unfiltered from the Columbia River. Raw water initially enters a reservoir near the 284-E Powerhouse where it is stored before treatment. Treating this water involves adding a coagulant (aluminum sulfate hydrate) that allows particulate settling to occur in the basin. After settling, the water is routed through a filter for final purification. The filter layers consist of porcelain beads, gravel, sand, and anthracite coal.

Average effluent flow rates from this facility are not available because a flowmeter has not been installed. The 283-E Water Treatment Facility is a nonradioactive facility; thus, radiation monitoring equipment is not used on the discharge of this stream. Wastewater sources to the 216-B-3 Expansion Ponds from the 283-E Water Treatment Facility include the following:

- Reservoir overflow

- Settling basin flushing

- Filter backflush water. 
2.3.6.1 Reservoir Overflow. Water is pumped from the Columbia River to a reservoir located at the 283-E Water Treatment Facility. Flow into the reservoir is controlled by manually adjusting an inlet valve. Should the reservoir overfill, the water goes to the 216-B-3 Expansion Ponds via the powerhouse ditch and pipeline.

2.3.6.2 Settling Basin Flushing. There are four settling basins used to purify raw water. The basins periodically are flushed to remove the solids that accumulate in the bottom during the settling period following coagulation. The flushwater containing the solids is sent to the 216-B-3 Expansion Ponds for final disposal.

2.3.6.3 Filter Backflush Water. Water passes through a filter that removes the coarse particles first and the finer particles last. This is done to minimize plugging of the filter. The first stage of the filter is the porcelain beads, followed by gravel, sand, and anthracite coal. Anthracite coal is used for removing noxious odors present in the water.

When the filter starts to plug, water is run through the filter in the reverse direction. This dislodges the fine and coarse particulates from the filter. The backflush water containing the particulates is sent to the 216-B-3 Expansion Ponds.

\subsubsection{4-E Powerhouse}

The 284-E Powerhouse is a coal-fired plant used to generate steam. Electricity normally is not generated at this facility; however, there is a standby steam-driven electrical generator at the powerhouse that provides standby power to the powerhouse and certain other facilities during power outages. There are five coal-fired boilers and a backup oil-fired boiler. The maximum production of steam is approximately $350,000 \mathrm{lb} /$ hour at $225 \mathrm{lb} / \mathrm{in}^{2}$. Steam generated at this facility is used at other process facilities (i.e., B Plant, PUREX Facility, and 242-A Evaporator) for heating and process operations.

One liquid effluent stream generated at the 284-E Powerhouse goes to the 3C Expansion Pond. Currently, a flowmeter has not been installed to monitor this flow. The 284-E Powerhouse is a nonradioactive facility; thus, radiation monitoring equipment is not used on the discharge of this stream. Sources that produce this effluent stream are as follows:

- Boiler blowdown

- Cooling water

- Floor drains

- Water softener regeneration solution.

For a more detailed description, see DOE-RL (1994a). 
WHC-EP-0813

\subsection{EFFLUENT CHARACTERISTICS}

The primary focus of this section is on current and projected characteristics of wastewater discharged to the $3 C$ Expansion Pond. However, historical discharge volumes are included for comparison purposes.

\subsection{DISCHARGE VOLUMES AND FLOW RATES}

The 3C Expansion Pond receives effluent wastewater from various facilities located in the 200 East Area. The majority of wastewater is from the PUREX Facility and B Plant. The largest contributing streams are B Plant cooling water, B Plant chemical sewer, and PUREX Facility chemical sewer. Additional routine sources of effluent are from the 242-A Evaporator, the 244-AR Vault, the 241-A aging waste ventilation system complex, the 283-E Water Treatment Facility, and the 284-E Powerhouse (see Figure 4). Discharge volumes released to the B Pond system from 1976 to the present are summarized in Table 1 and illustrated in Figure 6. During 1993, the volume of effluent discharged to the B Pond system averaged approximately $13,000 \mathrm{~L} / \mathrm{min}$

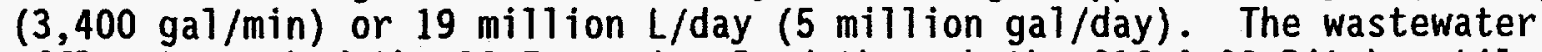
effluent reached the 3C Expansion Pond through the 216-A-29 Ditch unti1 February 1994. Since February 1994 the wastewater is being directly discharged to the 3C Expansion Pond via the 216-E-28A pipeline.

Anticipated flow rates to $3 C$ Expansion Pond after implementation of Project $W-252$ are summarized in Table 2. 
Table 1. Historical Discharge to the B Pond System.

\begin{tabular}{|c|c|}
\hline Year & Volume (L) \\
\hline 1976 & $3.43 \times 10^{9}$ \\
\hline 1977. & $3.76 \times 10^{9}$ \\
\hline 1978 & $4.37 \times 10^{9}$ \\
\hline 1979 & $3.47 \times 10^{9}$ \\
\hline 1980 & $4.41 \times 10^{9}$ \\
\hline 1981 & $6.11 \times 10^{9}$ \\
\hline 1982 & $5.17 \times 10^{9}$ \\
\hline 1983 & $7.04 \times 10^{9}$ \\
\hline 1984 & $5.32 \times 10^{9}$ \\
\hline 1985 & $5.32 \times 10^{9}$ \\
\hline 1986 & $2.28 \times 10^{10}$ \\
\hline 1987 & $2.22 \times 10^{10}$ \\
\hline 1988 & $2.67 \times 10^{10}$ \\
\hline 1989 & $1.47 \times 10^{10}$ \\
\hline 1990 & $8.37 \times 10^{9}$ \\
\hline 1991 & $7.48 \times 10^{9}$ \\
\hline 1992 & $5.04 \times 10^{8}$ \\
\hline 1993 & $4.74 \times 10^{9}$ \\
\hline 1994 & $3.34 \times 10^{9}$ \\
\hline
\end{tabular}


WHC-EP-0813

Figure 6. Discharge Volume to the B Pond System.

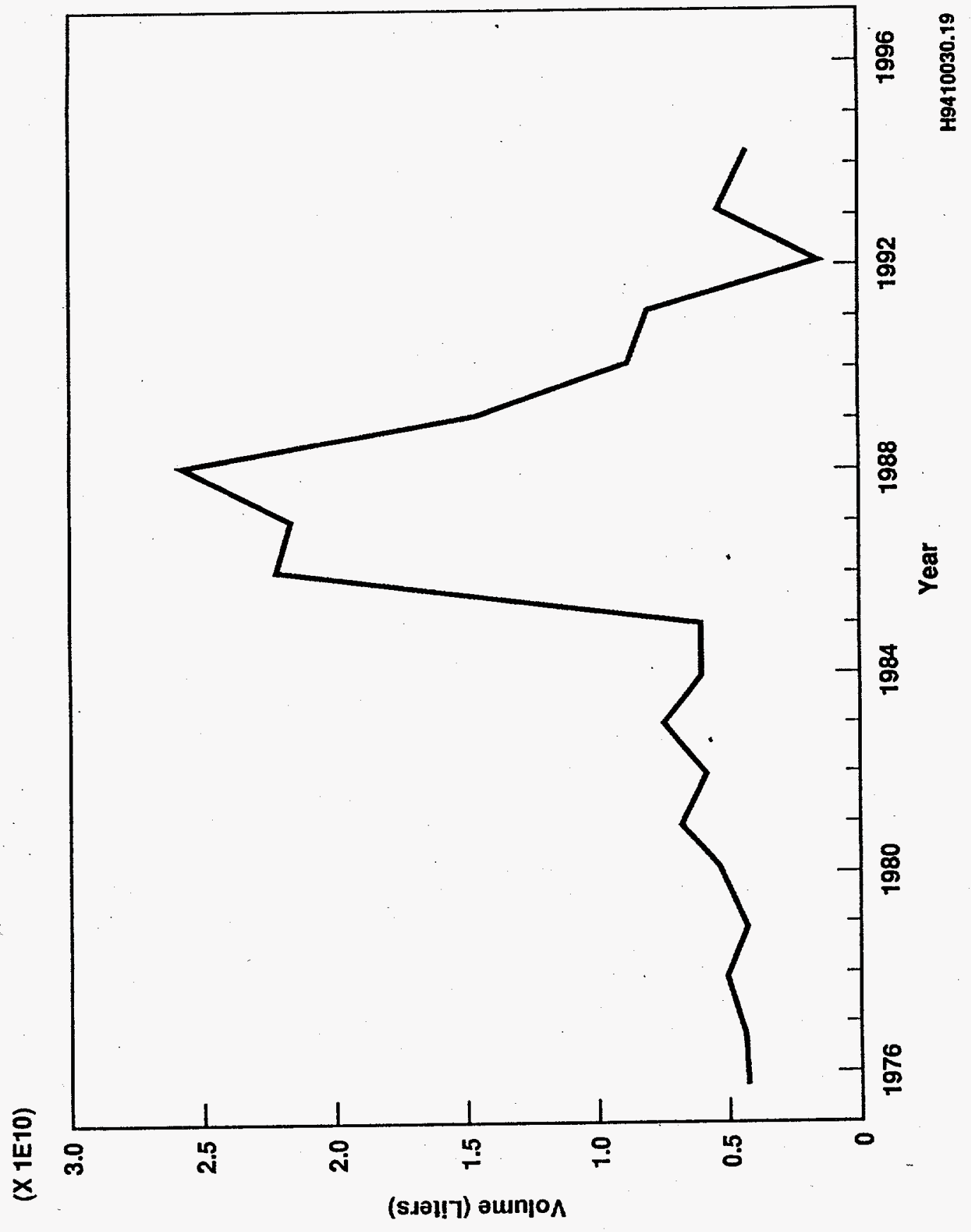


Table 2. Projected Flow Rate to the 216-B-3C Expansion Pond.

\begin{tabular}{|c|c|c|c|}
\hline Source & \multicolumn{3}{|c|}{ Flow rate $[\mathrm{L} / \mathrm{min}(\mathrm{gpm})]$} \\
\hline 242-A Evaporator cooling water & $\begin{array}{l}\text { Nonoperating: } \\
\text { Operating: } \\
\text { Maximum operating: }\end{array}$ & $\begin{array}{r}38 \\
10,000 \\
10,220 \\
\end{array}$ & $\begin{array}{r}(10) \\
(2,640) \\
(2,700) \\
\end{array}$ \\
\hline 242-A Evaporator steam condensate & $\begin{array}{l}\text { Nonoperating: } \\
\text { Operating: } \\
\text { Maximum operating: }\end{array}$ & $\begin{array}{r}0 \\
228 \\
568 \\
\end{array}$ & $\begin{array}{r}(0) \\
\langle 60\rangle \\
\langle(150)\end{array}$ \\
\hline 244-AR Vault cooling water & $\begin{array}{l}\text { Operating: } \\
\text { Maximum operating: }\end{array}$ & $\begin{array}{r}61 \\
114 \\
\end{array}$ & $\begin{array}{l}(16) \\
(30) \\
\end{array}$ \\
\hline B Plant cooling water & Routinely: & 4,920 & $(1,300)$ \\
\hline 241-A Tank Farms cooling water & Routinely: & 76 & (20) \\
\hline 284-E Powerplant wastewater & Routinely: & 322. & (85) \\
\hline PUREX Chemical sewer & Routinely: & 996 & (263) \\
\hline
\end{tabular}

\subsection{EFFLUENT CHEMICAL CONSTITUENTS}

As previously discussed, past operations of the B Pond system involved potential releases of a wide array of chemicals and radionuclides (DOE-RL 1994a). The chemical composition of wastewater discharged to the pond system in the past has been described in various documents (WHC 1990e; DOE-RL 1994a). However, the 3C expansion lobe, the focus of this assessment, is expected to receive only chemical constituents associated with Columbia River water (i.e., cooling water) and minor quantities of nonhazardous chemicals associated with water treatment. Thus, for purposes of this assessment it is assumed there are no constituents of concern directly associated with operation of the facility. The average total dissolved solids content should be two to three times lower than the ambient ground water beneath the facility.

As discussed in subsequent sections, the primary impact of wastewater disposal to the $3 C$ lobe will be the influence of the ground water mound on existing contaminant plumes from past B Pond and PUREX crib discharges and the influence of continued operation of the pond on ground water elevation and flow direction. 
WHC-EP-0813

\subsection{SITE DESCRIPTION}

Evaluation of the impact of continued wastewater disposal at B Pond requires consideration of the regional and site-specific geologic and hydrologic features that influence ground water movement near the disposal site. Accordingly, the following sections describe the regional setting followed by a more detailed description of stratigraphy and hydrology of the disposal site and immediate area. This information, together with discharge data and operational factors discussed in preceding sections, are then used to form an overall conceptual model of the impact of continued operation of the $3 \mathrm{C}$ expansion lobe. The conceptual model serves as the working hypothes is for the mathematical modeling (Section 5.3) and impact assessment and evaluation discussed in Chapter 6.0 .

\subsection{REGIONAL AND 200 EAST AREA GEOLOGY}

The Hanford Site is located in the Pasco Basin, a broad alluvial basin within the Columbia Plateau (Figure 7). The geology and hydrology of the Pasco Basin and Hanford Site have been discussed in numerous reports (i.e., Myers et a1. 1979; Myers and Price 1981; Gephart et a1. 1979; DOE 1987, 1988; Reidel and Hooper 1989; Reidel et al. 1992, 1994; Delaney et al. 1991; Lindsey 1991; Reidel and Fecht 1994a, 1994b). The reader is referred to these reports for detailed descriptions and geologic maps. Regional and sub-basin features that have a bearing on subsurface hydrologic and geologic conditions in the 200 East Area of the Hanford Site are summarized below.

\subsubsection{Regional}

The Columbia Plateau is a broad intermontane basin called the Columbia Basin. The structural framework of the Columbia Plateau is controlled by the Columbia River Basalt Group (CRBG). This rock has been folded and faulted during the past 17 million years, producing the present topography and structural relief of the Hanford site. The CRBG contains a series of aquifers that are bounded by the lava flows. These aquifers, some of which are important regional water sources, constitute the confined aquifer system that extends beneath the Hanford Site.

The principal structural unit that contains the Hanford Site is the Pasco Basin (see Figure 7). The Pasco Basin is one of the larger structural and topographic basins in the Columbia Plateau. The Pasco Basin is bounded on the north by the Saddle Mountains and on the south by Rattlesnake Mountain, the Rattlesnake Hills, and the eastern portion of the Horse Heaven Hills. Umtanum Ridge and Yakima Ridge plunge into the Pasco Basin forming, from north to south, the Wahluke, the Cold Creek, and the Benson Ranch synclines

(Figure 8). 
Figure 7. Geologic Location Map for the Hanford Site and the Pasco Basin.
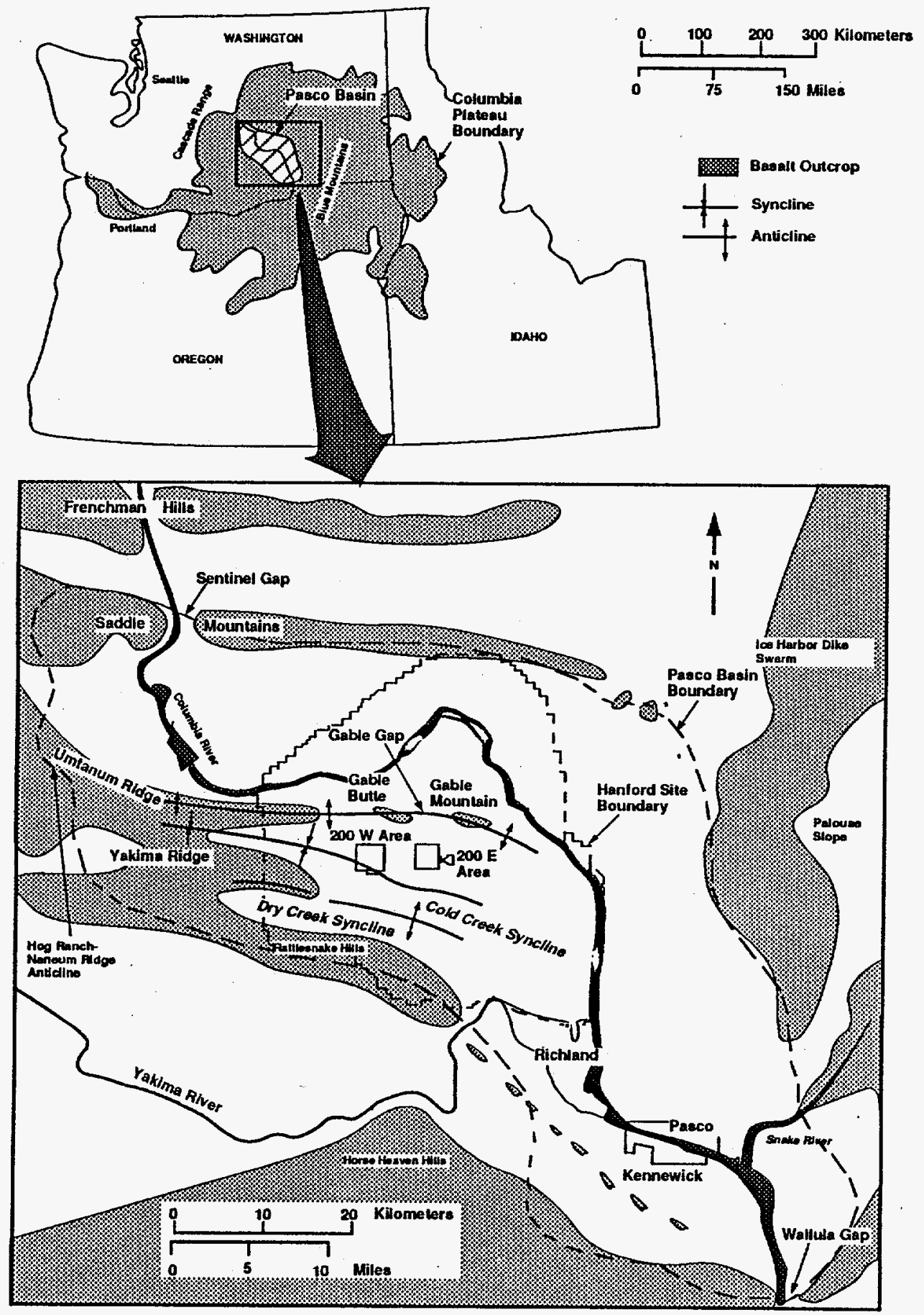

39103001.5 
Figure 8. Structural Contour Map On the Top of Basalt for the 200 Areas.

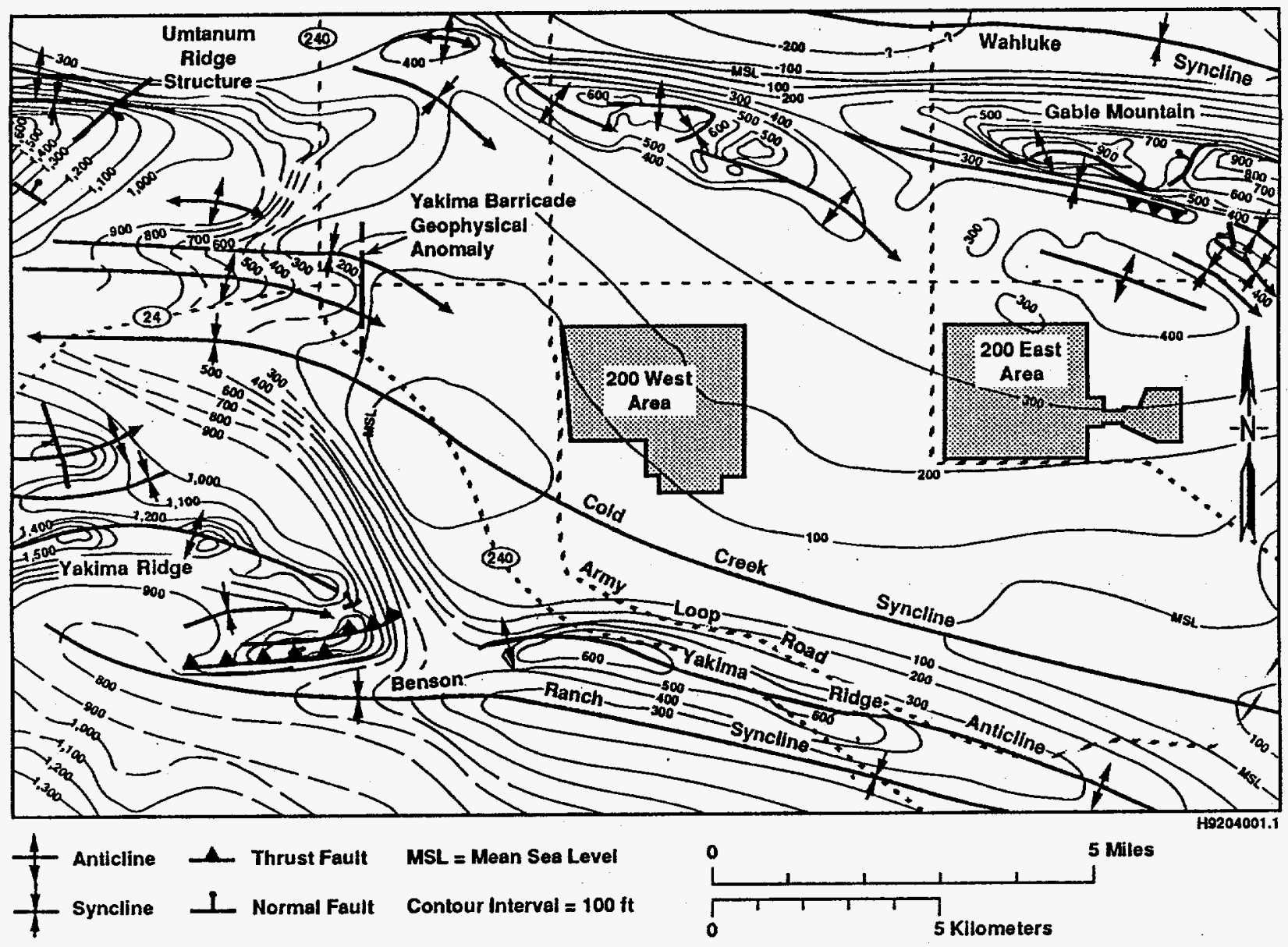

To convert to meters multiply by 0.3048 . 
WHC-EP-0813

\subsubsection{Areas}

The geology and hydrology of the 200 Areas have been the subject of much study and many reports over the past several decades (i.e., Myers et a1. 1979, Myers and Price 1981, Gephart et a1. 1979, Tallman et al. 1979, Graham et al. 1981, and Routson and Johnson 1990). The most recent work on the 200 East Area is by Lindsey et a1. (1992).

The 200 Areas 7 ie on the north 7 imb of the Cold Creek syncline. The uppermost flow of the CRBG is the Elephant Mountain Member. The suprabasalt stratigraphy consists of the Ringold Formation, the Plio-Pleistocene unit, the early Palouse soil, and the Hanford formation. The Ringold Formation is a series of interbedded gravels, sands, silts, and muds. Overlying this is the Plio-Pleistocene unit and early Palouse soil. The latter units are present only under 200 West Area and are predominantly eolian with distinct caliche stringers. The Hanford formation consists mainly of gravels with interbedded sands. Near the south end of the 200 West Area, some slackwater deposits are present.

The structural grain of the bedrock at the 200 East Area trends roughly east-west parallel to the Yakima Ridge and Umtanum Ridge-Gable Mountain (Figure 9). As a result, the Ringold Formation and the underlying CRBG gently dip to the south off the Umtanum Ridge anticline into the Cold Creek syncline. Major stratigraphic variations occur in a northeast-southwest direction parallel to the dip direction.

The stratigraphic section that overlies the CRBG in the 200 East Area and immediate vicinity is divided, from bottom to top, into (1) the Ringold Formation and (2) the Hanford formation (Figure 10).

\subsection{GEOMORPHOLOGY AND STRATIGRAPHY OF THE 216-B-3 POND}

\subsubsection{Geomorphology}

The terrain surrounding the 216-B-3 Pond is relatively flat and the average elevation is about $560 \mathrm{ft}(171 \mathrm{~m})$ above mean sea level. The prevailing wind is from the northwest, although strong winds are from the southwest. Sagebrush and cheatgrass cover the area except for access roads and the pond system itself. The 216-B-3 Pond system lies east of the Cold Creek Bar between the Umtanum-Gable Mountain anticlinal ridge and the Cold Creek syncline.

\subsubsection{Stratigraphy}

The stratigraphy of the 216-B-3 Pond system has been interpreted from the drilling of 24 boreholes and the correlation of sediments with data from the $\mathrm{W}-\mathrm{O} 49 \mathrm{H}$ site (Figure 11). The predominant stratigraphic units identified from borehole cuttings include the Hanford formation, the Ringold Formation, and the Elephant Mountain Member of the Saddle Mountain Basalts. The Plio-Pleistocene unit is not found within or near the 200 East Area. 
Figure 9. Structural Contour Map On the Top of Basalt for the 200 East Area and the B Pond System.

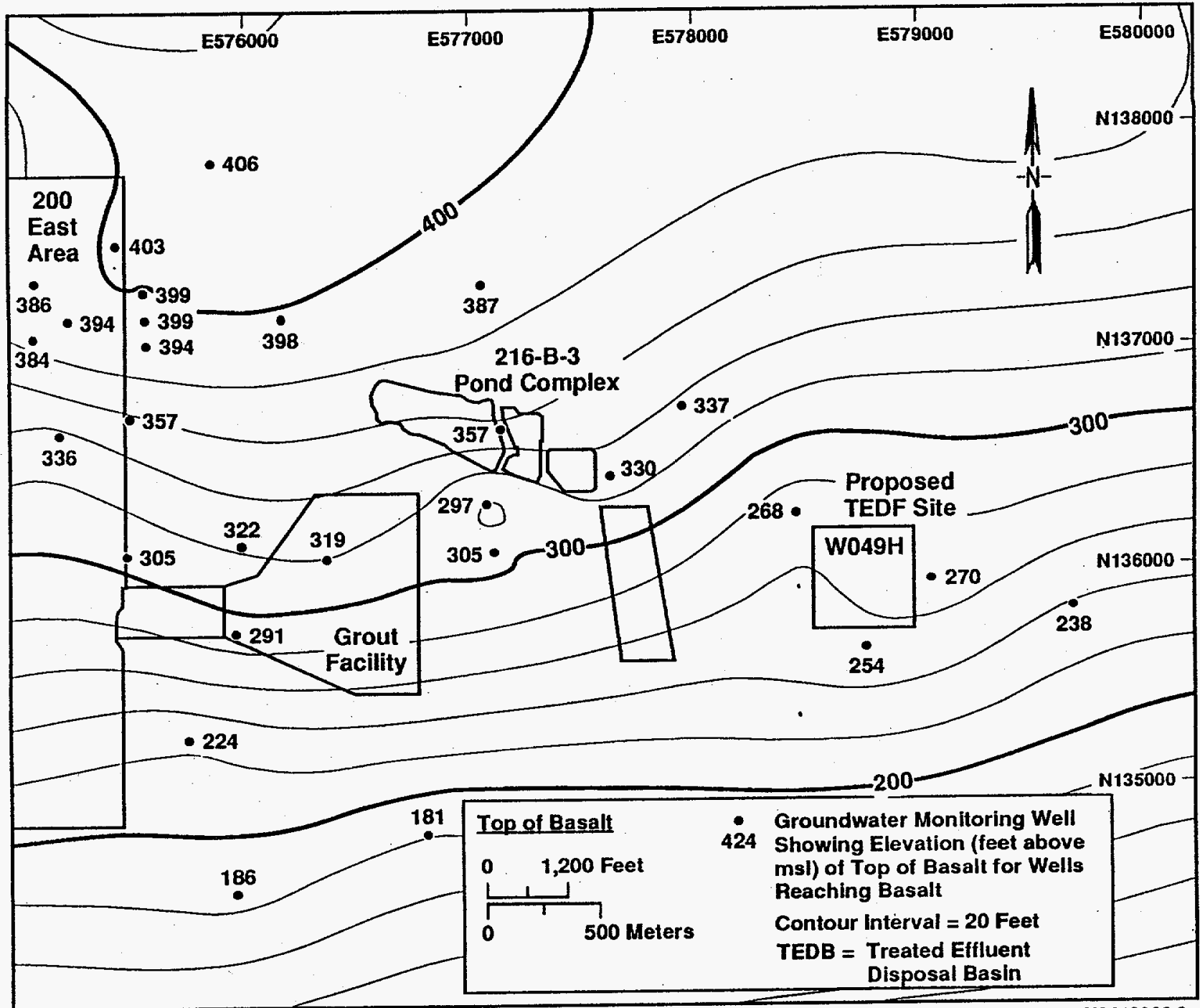


Figure 10. Stratigraphic Nomenclature for the Pasco Basin.

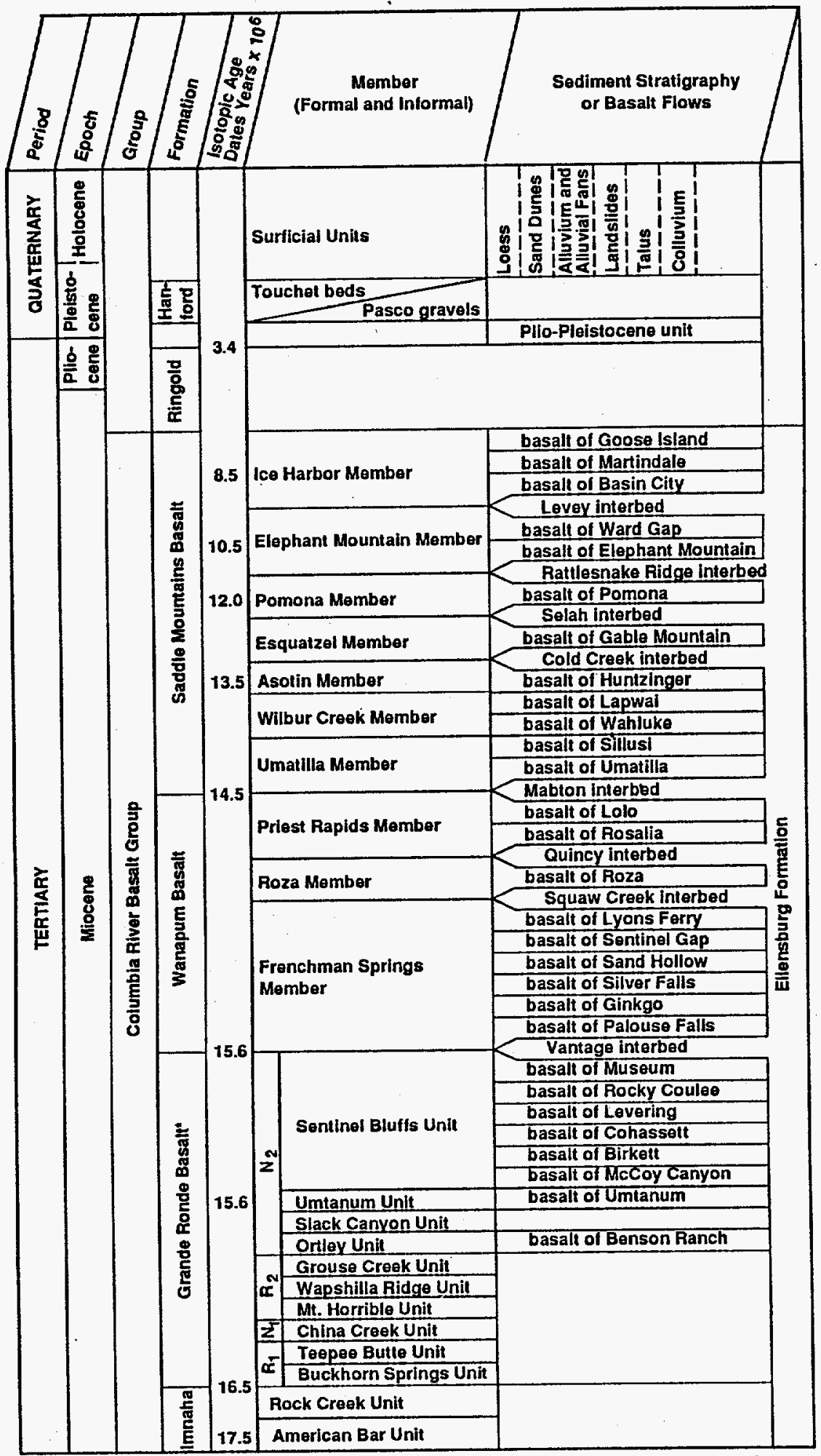

- The Grande Ronde Basalt consists of at least 120 major basalt flows. Only a fow flows have been named. $N_{2}, R_{2}, N_{1}$ and $R_{1}$ are magnetostratigraphic units. 


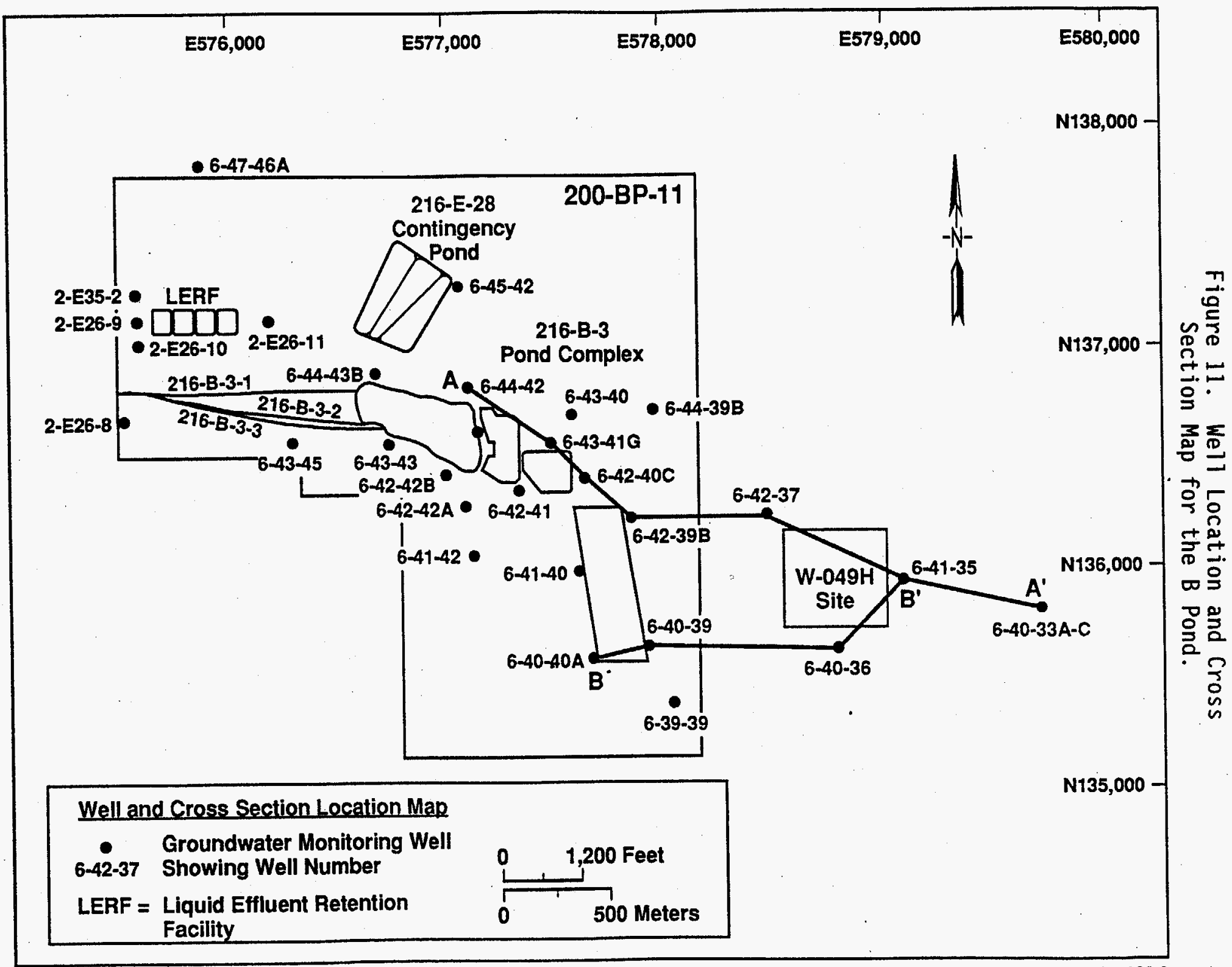


4.2.2.1 Hanford Formation. The Hanford formation consists of pebble to boulder gravel, fine- to coarse-grained sand, and silt. These deposits are divided into three facies (grave1, sand, and silt dominated) (Lindsey et a7. 1991, 1992). Three units of the Hanford formation were identified beneath the 216-B-3 Pond (Figures 12 and 13). These units are classified on the basis of lithology, petrography, stratigraphy, and pedogenic alteration. All three units were found in the 216-B-3 Pond area.

4.2.2.1.1 Upper Coarse Unit. The upper coarse unit is extremely variable in thickness and distribution. It ranges from 11 to $37 \mathrm{~m}$ (35 to $120 \mathrm{ft}$ ) thick and, although it is dominated by the gravel facies, it contains significant interstratified sand horizons. The unit is thinnest in the southwestern part of the site and thickens to the north and east. Outcrop observations show that silt-rich interbeds up to a meter thick are present in the unit and that these horizons are capable of generating perched water. These interbeds are in some cases continuous up to distances of at least several hundred meters. The contact between the upper coarse and underlying strata generally is extremely irregular. These irregularities are the result of the interfingering nature of these deposits and the absence of a distinct bounding surface.

4.2.2.1.2 Middle Fine Unit. The abundant sand-rich facies comprising the middle fine unit are thickest (up to $55 \mathrm{~m}$ [180 ft]) in the southwestern part of the site while pinching out to the east and north. Silty beds and horizons in this unit have the potential to form perched water zones, although the lateral continuity of these zones is questionable because of the presence of clastic dikes and pinchouts found in analogous strata elsewhere.

A sequence of interbedded sand and gravel in the lower part of the unit is locally well developed, especially to the east where the middle fine unit pinches out and interfingers with gravelly units (the upper and lower coarse units).

4.2.2.1.3 Lower Coarse Unit. The lower coarse is dominated by the gravel facies and also thickens to the north and southeast, ranging from 12 to $46 \mathrm{~m}$ ( 40 to $150 \mathrm{ft}$ ) thick. Like the upper coarse unit, interbeds of the sand facies and silt facies are present throughout the lower coarse unit. Silts have the potential to generate perched water in these gravels. Where the middle fine unit is absent, it is not possible to easily differentiate the upper and lower coarse units. At locations where the middle fine unit is absent, the contact between upper and lower coarse units is arbitrarily picked based on a projected trend from the nearest wells where the middle fine unit occurs.

4.2.2.2 Ringold Formation. The Ringold Formation consists of semi-indurated clay, silt, pedogenically altered sediment, fine- to coarse-grained sand, and granule to cobble gravel. Ringold strata typically are situated below the water table (Reidel et ai. 1992). The two units of the Ringold Formation found beneath the 216-B-3 Pond system include the lower mud unit and the Ringold unit $A$ (see Figures 12 and 13 ). 
Figure 12. Cross Section A-A' Across the 216-B-3 Pond System, Indicating Hydrostratigraphic Units with Representative Properties.

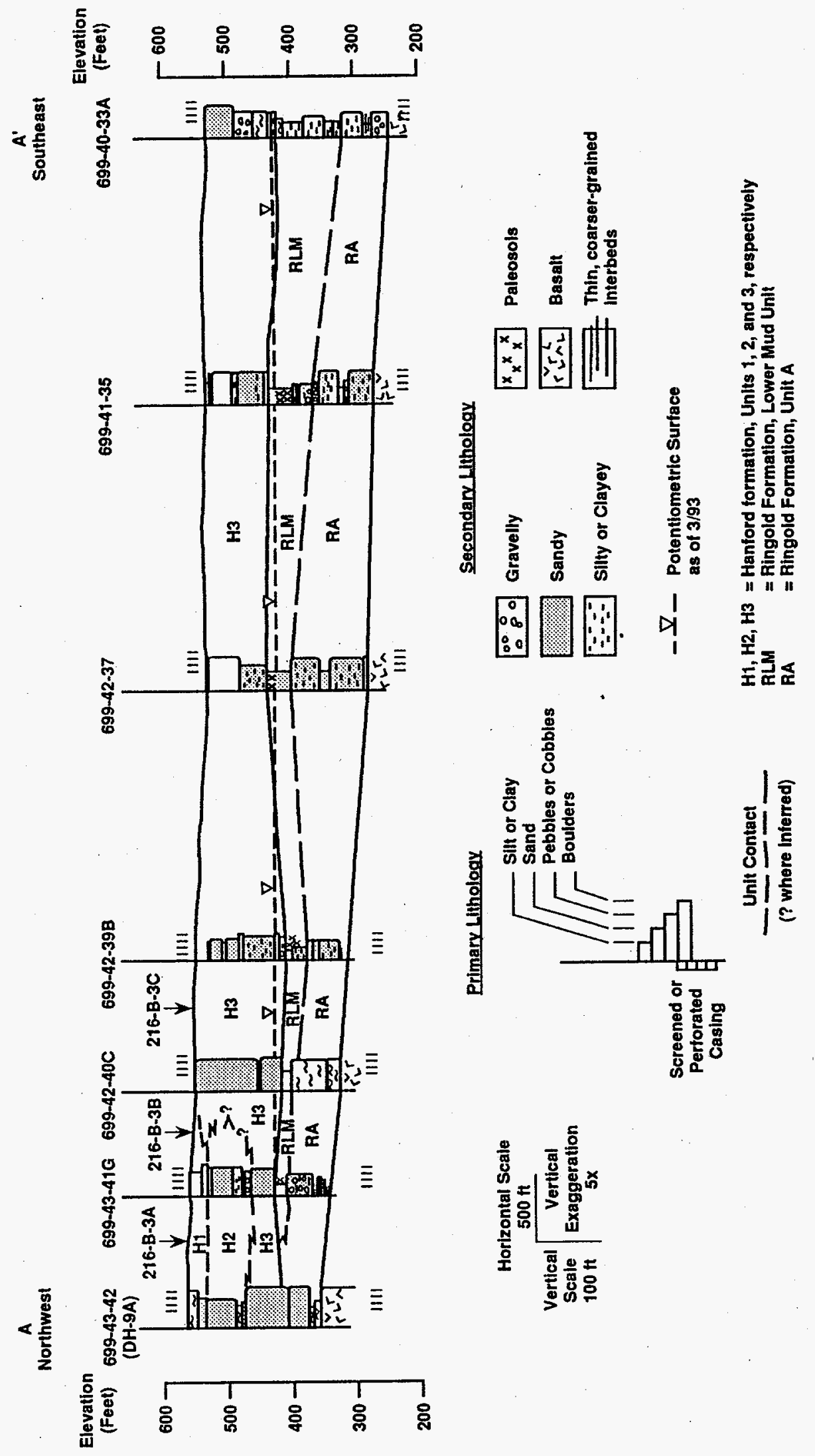


Figure 13. Cross Section B-B' Across the 216-B-3 Pond System, Indicating Hydrostratigraphic Units with Representative Properties.

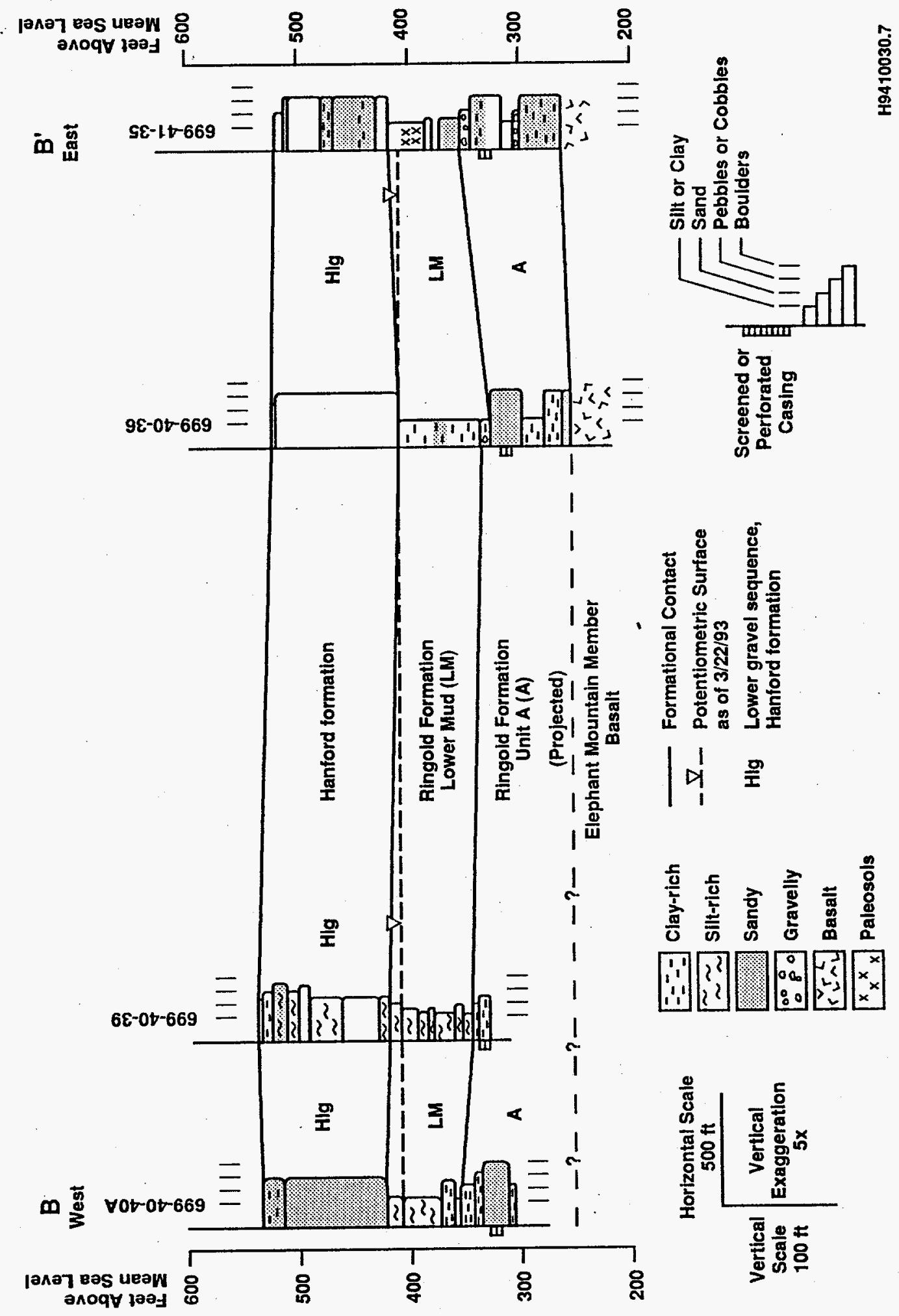


4.2.2.2.1 Lower Mud Unit. The lower mud unit is comprised by the lacustrine facies association and the overbank facies as described in Delaney et a1. (1991). The unit in the area of the 216-B-3 Pond is a sequence of silts and clays separated from the Hanford formation by a sharp contact. The lower mud varies in thickness from $23 \mathrm{~m}(75 \mathrm{ft})$ in the southeast near the $3 C$ expansion lobe (we11 699-40-39) to approximately $6 \mathrm{~m}$ (20 ft) in thickness in the northwest near the main lobe (we11 699-43-41F). The unit completely disappears immediately north, west, and east beyond the area of Figures 12 and 13 surrounding the main lobe (e.g., see Figure 12).

4.2.2.2.2 Unit A. Unit $A$ is defined on the basis of stratigraphic position with respect to the lower mud sequence. This unit corresponds to fluvial gravels of the basal Ringold unit as defined by DOE (1988). Unit thicknesses of up to $46 \mathrm{~m}(150 \mathrm{ft})$ have been logged in boreholes within the Hanford Site. However, the thickness of the unit beneath the 216-B-3 Pond system is approximately $21 \mathrm{~m}(70 \mathrm{ft})$. The unit disappears completely north of the 216-B-3 Pond system.

\subsection{REGIONAL AND 200 EAST AREA HYDROGEOLOGY}

\subsubsection{Regional}

Primary surface water features associated with the Hanford Site and vicinity are the Columbia River and its major tributaries, and the Yakima, Snake, and Walla Walla Rivers. West Lake, about 4 ha $(10$ acres) in size. and less than $0.9 \mathrm{~m}(3 \mathrm{ft})$ deep, is the only natural lake within the Hanford Site (DOE 1988). Wastewater ponds, cribs, and ditches associated with nuclear fuel processing and waste disposal activities are also present on the Hanford Site (Figure 14).

The Columbia River flows through the northern part and along the eastern border of the Hanford Site. This section of river, the Hanford Reach, extends from Priest Rapids Dam to the headwaters of Lake Wallula (the reservoir behind McNary Dam).

Approximately one-third of the Hanford Site is drained by the Yakima River system. Cold Creek and its tributary, Dry Creek, are ephemeral streams within the Yakima River drainage system. Both streams drain areas along the western part of the Hanford Site and cross the southwestern part of the Hanford Site toward the Yakima River. Surface flow, which may occur during spring runoff or after heavier-than-normal precipitation, infiltrates and disappears into the surface sediments. Rattlesnake Springs, 1ocated on the western part of the Hanford Site, forms a small surface stream that flows for about $2.9 \mathrm{~km}(1.8 \mathrm{mi})$ before infiltrating into the ground.

The hydrogeology of the Pasco Basin is characterized by a multiaquifer system that consists of four hydrogeologic units that correspond to the upper three formations of the CRBG (Grande Ronde Basalt, Wanapum Basalt, and Saddle Mountains Basalt) and the suprabasalt sediments. The basalt aquifers consist of the tholeiitic flood basalts of the CRBG and relatively minor amounts of intercalated fluvial and volcaniclastic sediments of the Ellensburg Formation. The suprabasalt sediment or uppermost aquifer system consists of fluvial, 
Figure 14. Location of Surface Water Bodies on the Hanford Site (DOE 1988).

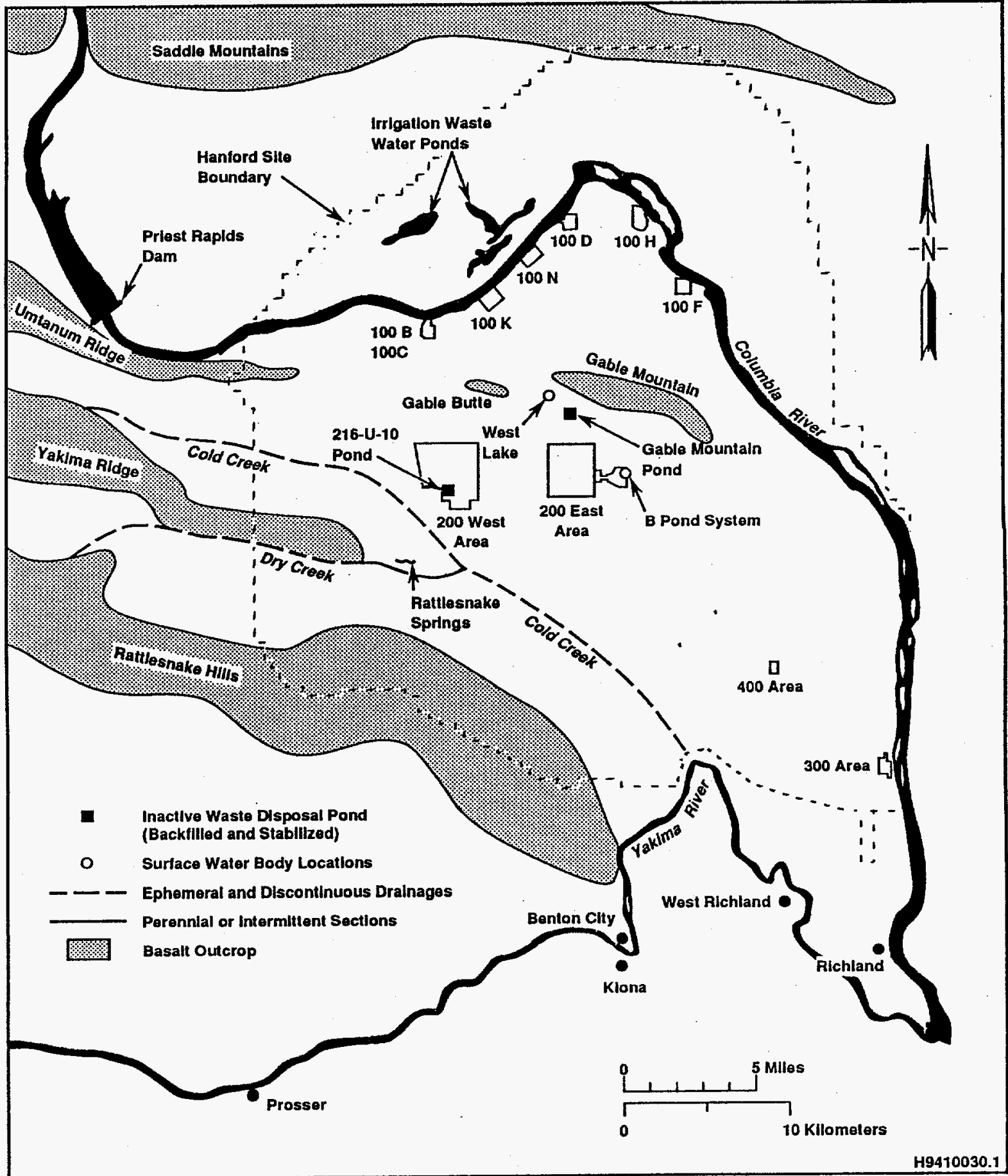


WHC-EP-0813

lacustrine, and glaciofluvial sediments. This aquifer is regionally unconfined and is contained largely within the Ringold Formation and Hanford formation.

The base of the uppermost aquifer system is defined as the top of the uppermost basalt flow. However, fine-grained overbank and lacustrine deposits in the Ringold Formation locally form confining layers for Ringold fluvial gravels underlying unit $E$. The uppermost aquifer system is bound laterally by anticlinal basalt ridges and is approximately $152.4 \mathrm{~m}$ (500 ft) thick near the center of the Pasco Basin.

Sources of natural recharge to the uppermost aquifer system are rainfall and runoff from the higher bordering elevations, water infiltrating from sma 11 ephemeral streams, and river water along influent reaches of the Yakima and Columbia Rivers. The movement of precipitation through the unsaturated (vadose) zone has been studied at several locations on the Hanford Site (Gee 1987; Routson and Johnson 1990; Rockhold et al. 1988). Conclusions from these studies vary. Gee (1987) and Routson and Johnson (1990) concluded that no downward percolation of precipitation occurs on the 200 Areas Plateau where the sediments are layered and vary in texture, and that nearly all moisture penetrating the soil is removed by evapotranspiration. Rockhold et al. (1988) suggested that downward water movement below the root zone is common in the 300 Area where soils are coarse textured and precipitation was above normal.

Artificial recharge of the uppermost aquifer system occurs from the disposal of large volumes of wastewater on the Hanford Site (principally in the 200 Areas) and from large irrigation projects surrounding the Hanford Site. Effluent disposal at the Hanford Site altered these hydraulic gradients and flow directions. Before operations at the Hanford Site began in 1944, the hydraulic gradient in all but the southwesternmost portion of the Hanford Site was approximately $1.5 \mathrm{~m} / \mathrm{km}(5 \mathrm{ft} / \mathrm{mi})$. Regional ground water flow was generally toward the east-northeast, although the flow north of Gable Mountain was more to the north. Ground water flow north of Gable Mountain now trends in a more northeasterly direction as a result of mounding near reactors and flow through Gable Gap. South of Gable Mountain, flow is interrupted locally by basalt anticlines that extend above the water table.

\subsubsection{East Area/Disposal Site Hydrology}

4.3.2.1 Hydrology of the 216-B-3 Pond System. The uppermost aquifer underlying the 216-B-3 Pond occurs in unconfined and confined conditions. The unconfined aquifer occurs mainly within the consolidated, suprabasalt sediments of the Ringold Formation (WHC 1990d). The base of the unconfined aquifer is from about 46 to $49 \mathrm{~m}$ (150 to $160 \mathrm{ft}$ ) below land surface. The top of the basalt, and the lower mud sequence of the Ringold Formation in some areas, form the base of the unconfined aquifer at the 216-B-3 Pond. The lower mud sequence and the gravel unit $A$ of the Ringold Formation, and the Elephant Mountain Member of the Saddle Mountain Basalt form the confined system.

Ground water flow in the unconfined aquifer near the 216-B-3 Pond is radially distributed with the highest gradient to the southwest (Figure 15). A combination of high-volume wastewater discharges, structural control, and stratigraphic heterogeneities within the unconfined aquifer contribute to this 


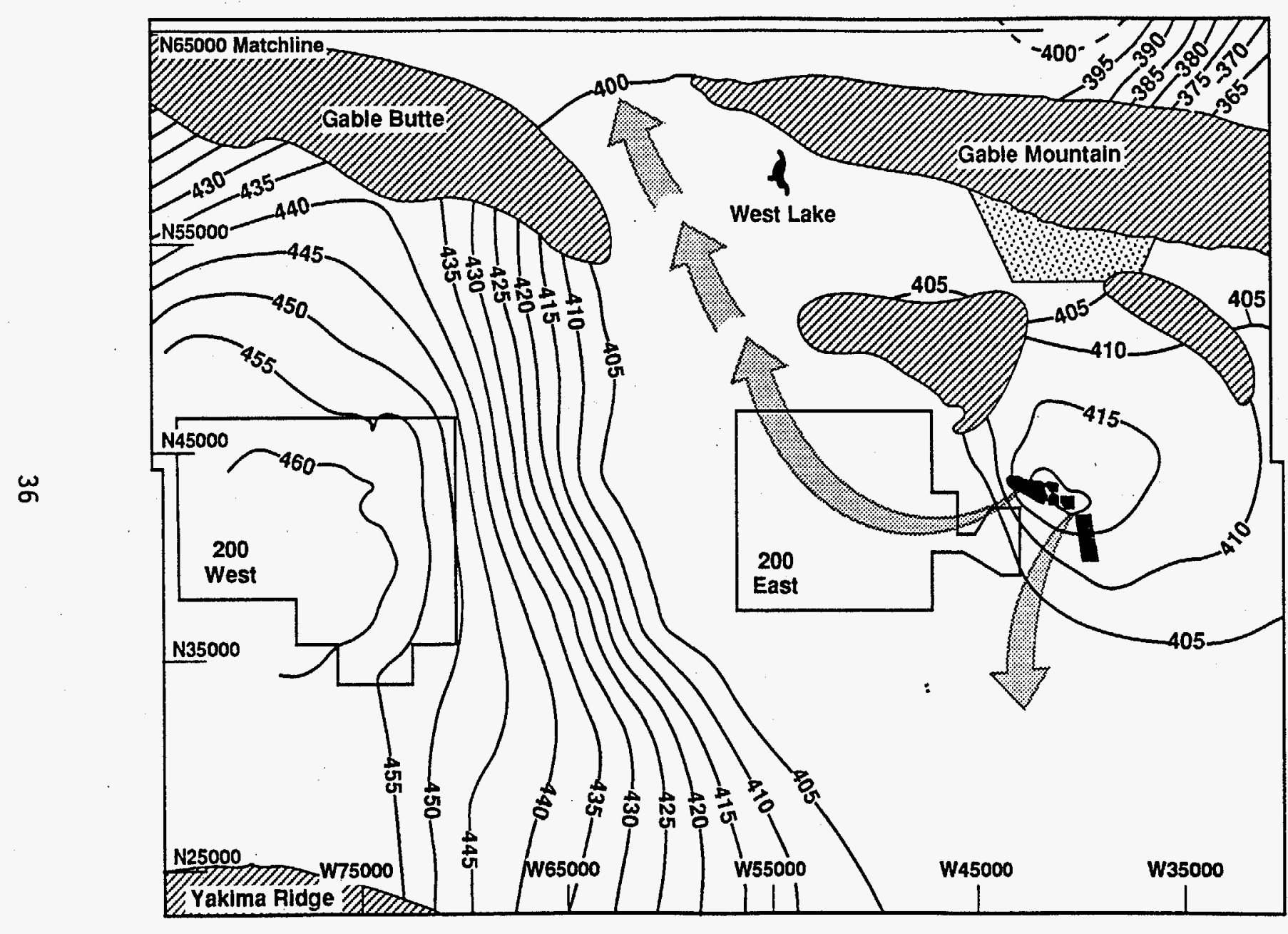

200 Areas

Water Table Elevation December 1993

\section{- _ - The dashed line indicates a contour \\ line generated due \\ to unusual data. \\ (Kasza et al. 1990)}

-400- Groundwater Table

Elevation

$\frac{7}{5}$

Contour Interval $=5$

ज

EIIII

Ponds

Areas where the

basalt surface is generally above the

water table

Nئㅇ

$\stackrel{\mathbb{7}}{\longrightarrow}$

Areas of confllicting data

욤

The 200 Areas water level elevation map has been prepared by the

Geohydrologic Support

Function, Westinghouse

Hanford Company.

Note: To convert to metric, multiply elevation (ft) by 0.3048 to obtain elevation (m).

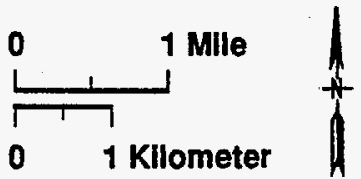

H9410030.30 
gradient. A basalt subcrop controls ground water flow on the north side of the 216-B-3 Pond, diverting it to the southwest (see Figure 15). The transition from the Hanford formation to the Ringold Formation as the predominant unconfined aquifer, with the resulting reduction in transmissivity, also constrains southwesterly flow.

Information on the aquifer conditions beneath the 216-B-3 Pond system are summarized from well $10 \mathrm{~g}$ data, hydraulic test results, water table maps, and various published reports. The depth to the water table at the 216-B-3 Pond is about 38 to $46 \mathrm{~m}$ (125 to $150 \mathrm{ft}$ ). The overlying Hanford formation extends below the water table in the western portion of 216-B-3 Pond (WHC 1990d). The lower 3.4 to $6.1 \mathrm{~m}$ (11 to $20 \mathrm{ft}$ ) of the Hanford formation is saturated.

The Hanford formation is unconfined and highly transmissive. The transmissivity values calculated from aquifer tests range from approximately 3,437 to $7,060 \mathrm{~m}^{2} /$ day $\left(37,000\right.$ to $76,000 \mathrm{ft}^{2} /$ day) (WHC 1990d). The average hydraulic conductivity of this upper portion of the aquifer ranges from approximately 641 to $1,281 \mathrm{~m} /$ day $(2,100$ to $4,200 \mathrm{ft} /$ day $)$.

The Ringold Formation occurs both in confined and unconfined conditions in the vicinity of the 216-B-3 Pond. The Ringold Formation gravel unit $A$ is confined from above by the lower mud unit and from below by the Elephant Mountain Basalt. Transmissivity of the confined Ringold Formation gravel, based on aquifer testing, varies from 0.19 to $4.2 \mathrm{~m}^{2}$ day ( 2 to $45 \mathrm{ft}^{2} / \mathrm{day}$ ). This corresponds to a hydraulic conductivity of approximately 0.06 to $1.4 \mathrm{~m} /$ day ( 0.2 to $4.5 \mathrm{ft} /$ day) (WHC $1990 \mathrm{~d}$ ). The results of testing in other wells near the 216-B-3 Pond, however, indicate extreme variability in Ringold Formation transmissivities. Multiple-well constant-discharge testing at we 11 699-42-40C yielded transmissivities of 95 to $110 \mathrm{~m}^{2} / \mathrm{day}$ (310 to $360 \mathrm{ft}^{2} /$ day). The contrast in transmissivity is attributed to differences in the stratigraphic intervals tested. Testing in well 699-44-43B occurred in the upper portion of the aquifer, whereas the testing at well 699-42-40C occurred in the lowermost sediments of the Ringold Formation (WHC 1990d).

Transmissivity in the lower mud unit is estimated to be $9.3 \times 10^{-4} \mathrm{~m}^{2} /$ day (0.01 $\mathrm{ft}^{2} /$ day) (WHC 1990d). Laboratory analysis (constant-head testing) of the confining unit yielded a hydraulic conductivity of approximately $6.1 \times 10^{-4} \mathrm{~m} /$ day $(0.002 \mathrm{ft} /$ day) (WHC $1990 \mathrm{~d}$ ).

The vertical hydraulic conductivity of the Elephant Mountain Member has been estimated between $10^{-12}$ and $1.5 \times 10^{-5} \mathrm{~m} / \mathrm{second}\left(10^{-6}\right.$ and $4.3 \mathrm{ft} / \mathrm{day}$ ). These values are based on simplifying assumptions for model calibration (DOE 1988).

Slug testing in well 699-44-43B in the unconfined Ringold Formation gravel unit $A$ exhibited similar hydraulic conductivities as the confined gravel unit $A$ at the lower range (1.4 m/day [4.7 ft/day]) (WHC 1990d). These values are conditional and are subject to several limitations. The most substantial limitation is the small diameter of influence that slug testing has on the aquifer. There is considerable evidence that the only area affected by this particular test is the filter pack immediately surrounding the screened interval. 
4.3.2.2 Hydraulic Gradients. Water level measurements have been taken in previously existing wells since 1987, and in RCRA-compliant wells since 1988, to evaluate horizontal hydraulic gradients. The initial measurements were made at least a month after all drilling and testing activities ceased in newly installed wells; therefore, static conditions were observed.

Ground water flow is generally in a radial direction beneath the 216-B-3 Pond system. This trend will continue until ground water elevations return to their pre-production levels, or until discharge patterns change in the 200 East Area. Sections of the 216-B-3 Pond are currently being decommissioned and complete cessation of discharges to the system are scheduled for mid-1997. The effluents that are presently directed to 216-B-3 Pond ( $C$ lobe) will be sent to the disposal area at the W-049H facility.

Horizontal head gradient, as determined by water level measurement, is estimated to be between 0.001 and 0.008 in the region of the 216-B-3 Pond system. Vertical head gradients are estimated from four shallow/deep well pairs: wells 699-43-42J/42B, 699-40-40A/40B, 699-42-39A/39B, and 699-43-41E/41G (see Figure 2). Expectedly, vertical hydraulic gradients ranged from 0.007 to 0.08 , roughty 10 times the estimated horizontal component of head gradient (DOE-RL 1994b).

\subsection{GROUND WATER QUALITY}

The major recent and past ground water contaminants in the 200 East Area resulted from PUREX process condensates containing tritium, nitric acid carryover, and iodine-129. The large volumes associated with these waste streams were discharged via two "clusters" of cribs or drain fields located in the southeastern corner of the 200 East Area. These two groups are discussed collectively to facilitate correlation with plume patterns and projection of trends. Also discussed are other significant sources of ground water contamination that resulted from past disposal activities at the BY cribs, B Plant cribs, and the 216-B-5 reverse wel1. Additionally, the effect of large volumes of uncontaminated cooling water from the $B$ Pond system on plume distribution patterns and chemical composition is considered.

\subsubsection{6-B-3 Pond System and Adjacent Disposal Facilities}

As previously discussed, the $B$ Pond system consists of the original pond (216-B-3), three expansion lobes (3A, 3B, and 3C), and several ditches (see Figure 2). The 216-B-3 Pond began receiving liquid effluent in 1945, and the three expansion lobes were placed in service in 1983, 1984, and 1985, respectively. Liquid effluent streams discharged to the pond system consist primarily of cooling water and steam condensate. In 1985, a major increase in discharge rate to the $B$ Pond system occurred because of closure of Gable Mountain Pond (216-A-25). This resulted in nearly a doubling of the volume of wastewater discharged to the ground in the 200 East Area. Major shifts in plume transport rate and direction are attributed to this major change in wastewater management. The present water table and flow directions are shown in Figure 15. 
Past discharges included chemical waste as well as spills. The latter occurrences may have resulted in significant soil column buildup of strontium-90 and cesium-137 in the original 216-B-3 Pond. Other spills included cadmium nitrate, hydrazine, and ammonium fluoride/nitrate (WHC 1990d, 1990e).

The ground water quality survey for the Liquid Effluent Study conducted in 1989-1990 included the Appendix IX 1ist of hazardous constituents as well as site-specific radionuclides in 12 wells located around the pond system. This survey did not reveal any anomalously high contaminant concentrations other than manganese in one or two wells, which was attributed to natural conditions (reducing conditions or low-dissolved oxygen).

Based on the above considerations, the major impact of recent and future B Pond system discharges on 200 East Area ground water quality is to

(1) dilute existing ground water contamination in the vicinity of the pond and (2) control the rate and direction of ground-water movement in the 200 East Area. Because most of the water discharged to the B Pond system in the recent past is river water which has lower dissolved solids than ambient ground water, the major chemical composition of ground water in the 200 East Area is markedly altered because of dilution. For example, if dilution is the only change that occurs, pond water with an average conductivity of $140 \mu \mathrm{S} / \mathrm{cm}$ should be easily discernable as it mixes with ambient ground water having an average specific conductivity of $380 \mu \mathrm{S} / \mathrm{cm}$. The ground water dilution effect is clearly illustrated in a contour map of specific conductivity. (Figure 16).

4.4.1.1 Interaction with Contaminant Plumes from Adjacent Facilities. The effect of $B$ Pond on contaminant distribution patterns is dramatically il lustrated at the 216-A-37-1 and 216-A-30 Cribs (Figure 17). The 216-A-37-1 Crib received evaporator/process condensate containing high concentrations of tritium until early 1989, after which the contaminant stream was collected and stored. The 216-A-30 Crib is located immediately downgradient from the 216-A-37-1 Crib but did not receive tritiated wastewater. The concentration-history plot (Figure 18) of tritium in monitoring wells at these cribs shows the influence of the B Pond mound, which causes ground water to flow westward (i.e., opposite the general direction of ground water flow across the Hanford Site in this area). In addition, the concentration-history plot also illustrates the rapid change in contaminant concentrations near certain cribs in response to operational changes in wastewater disposal. Figure 19 illustrates the rate at which the large peak in tritium is moving away (toward the west-southwest). This "pulse" will continue to move through the area, as well as any associated mobile chemical contaminants, at a rate of approximately $3 \mathrm{~m} / \mathrm{day}(10 \mathrm{ft} / \mathrm{day})$. This same rate of apparent movement can be expected for any contaminants introduced to the ground water from past sources such as the 216-A-29 Ditch and the 216-A-8 and 216-A-24 Cribs. Residual contaminants beneath adjacent facilities should thus be diluted and displaced as the relatively noncontaminated $B$ Pond water moves across the 200 East Area from east-southeast to west-northwest.

4.4.1.2 216-A-45 and Related Cribs. The other major source area or cluster of sources for the 200 East Area is the group of PUREX cribs located immediately south of the plant (Figure 20). This set of cribs accounts for 
Figure 16. Specific Conductivity Map for the 200 East Area (Johnson 1993).

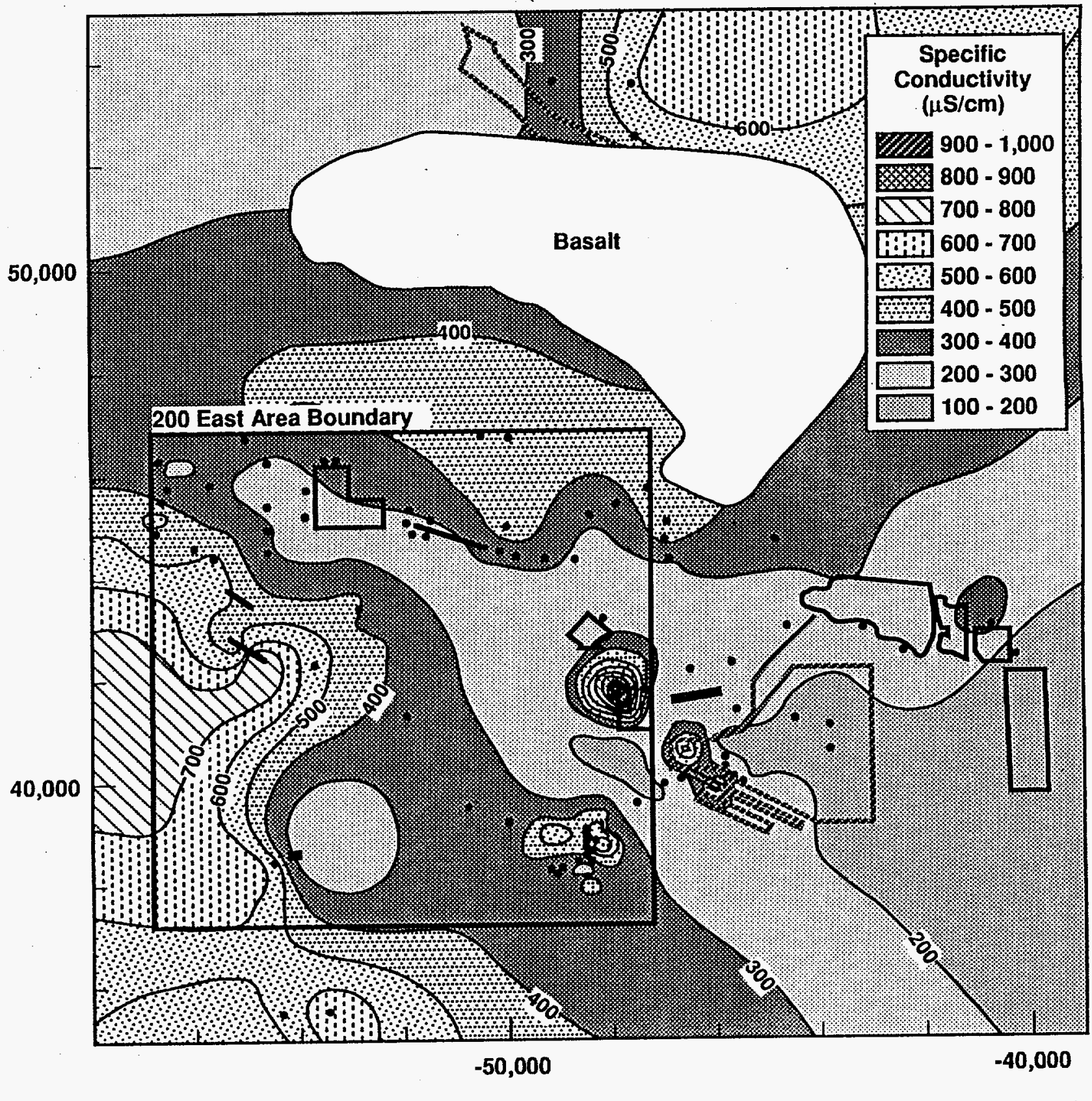

$H 9410030.25$ 
Figure 17. Concentration Plot for Tritium at the 216-A-37-1 Crib Wells.
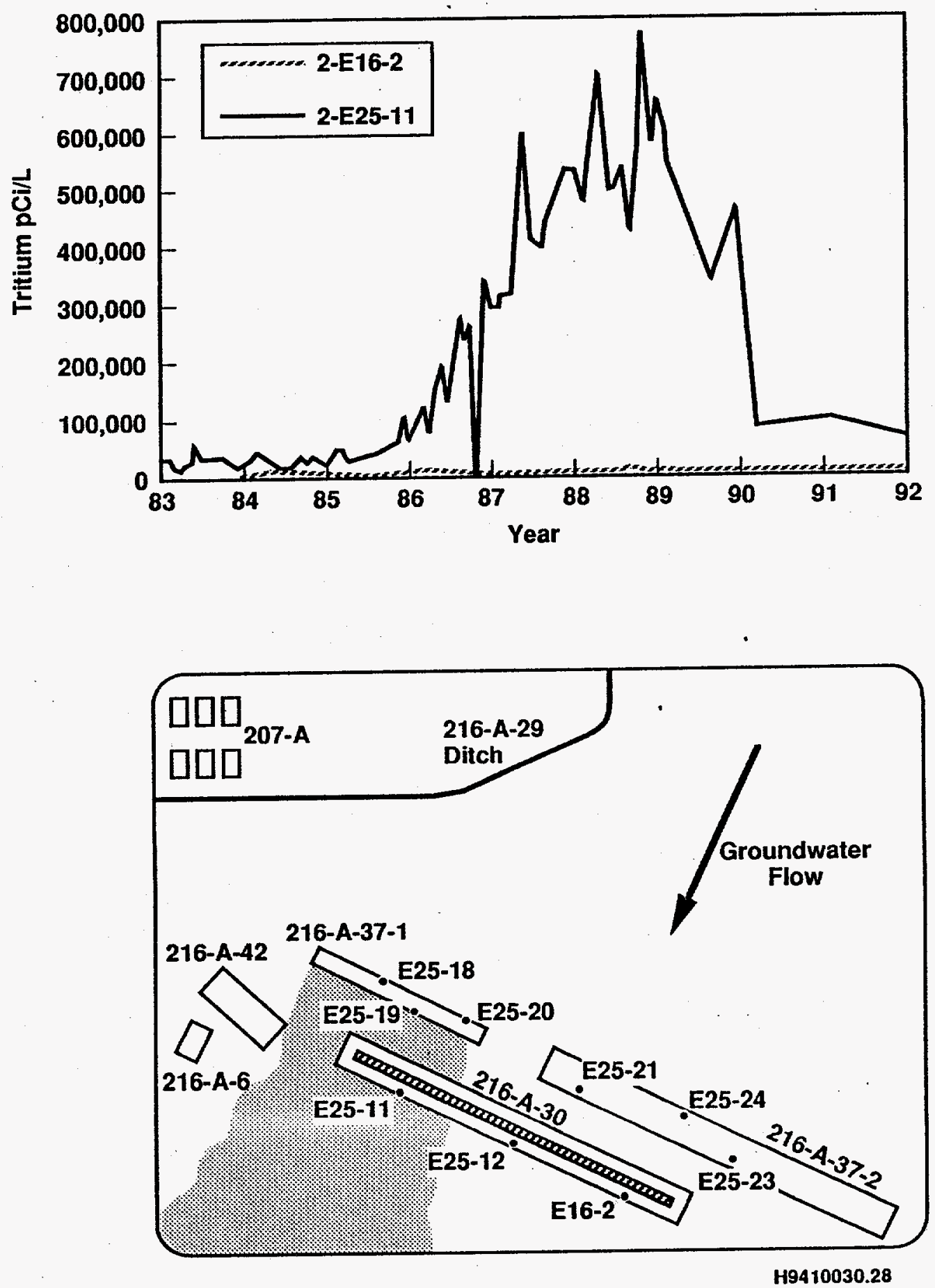
Figure 18. Concentration-History Plot of Tritium.

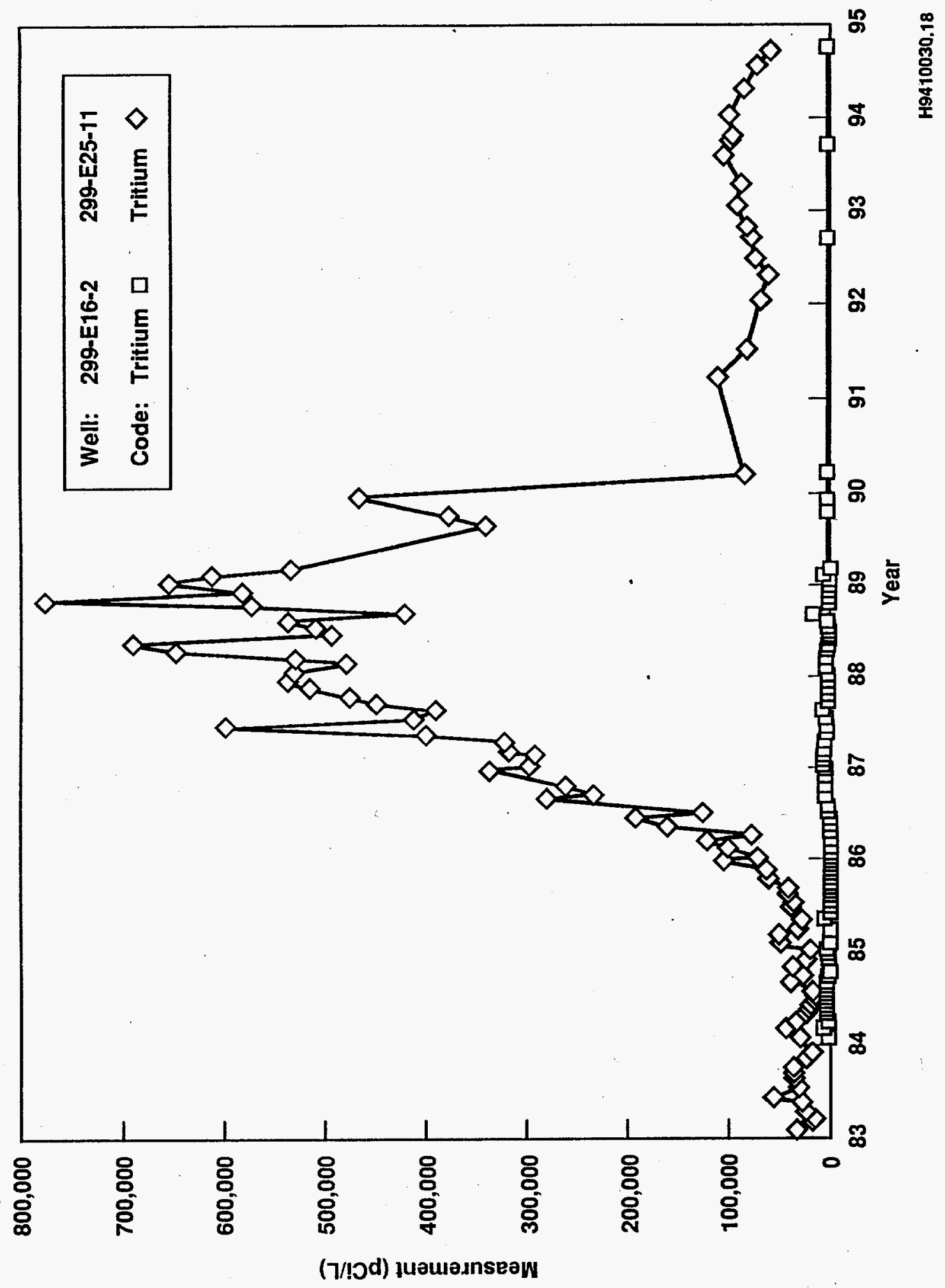



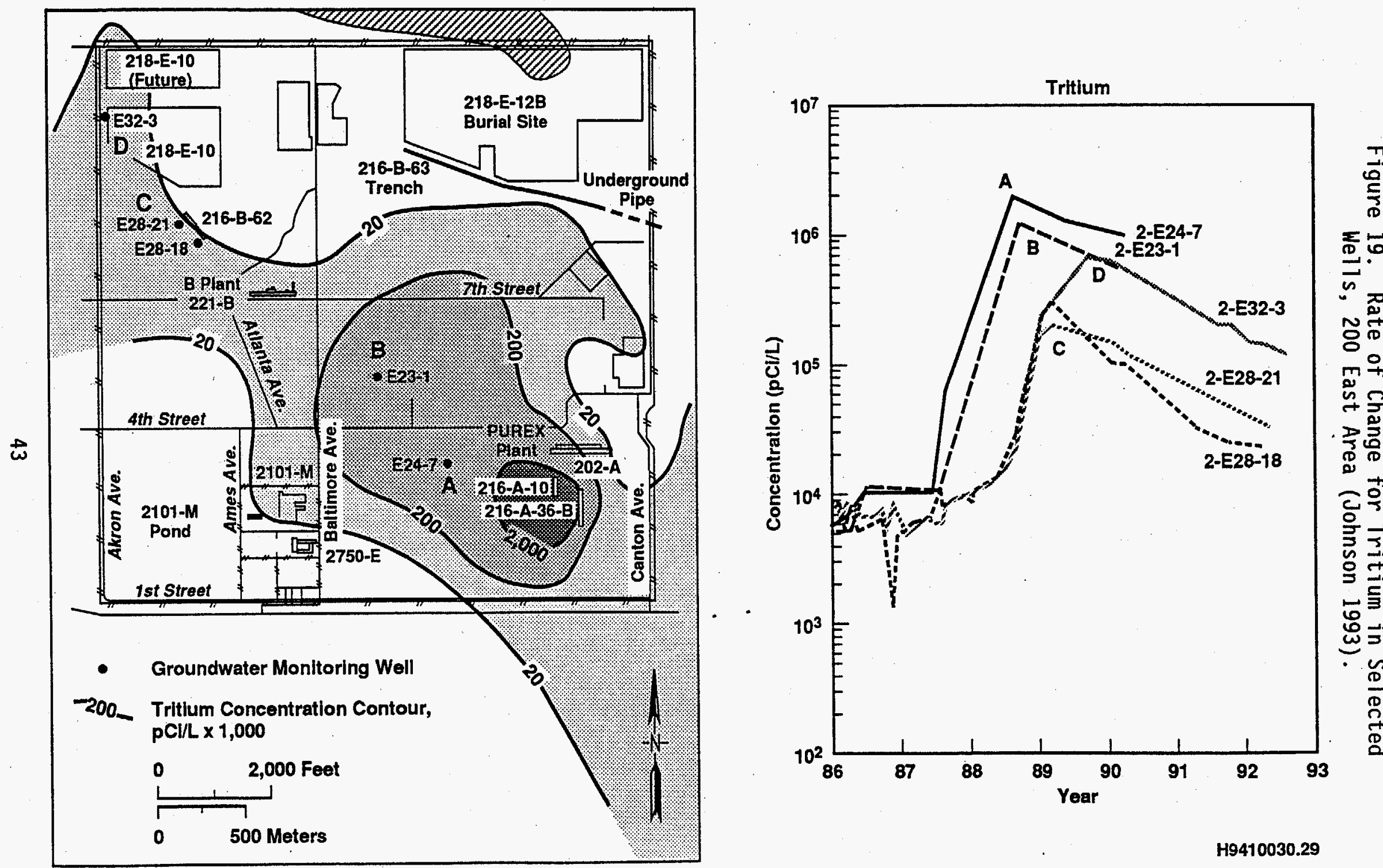
Figure 20. 216-A-45 Cribs.

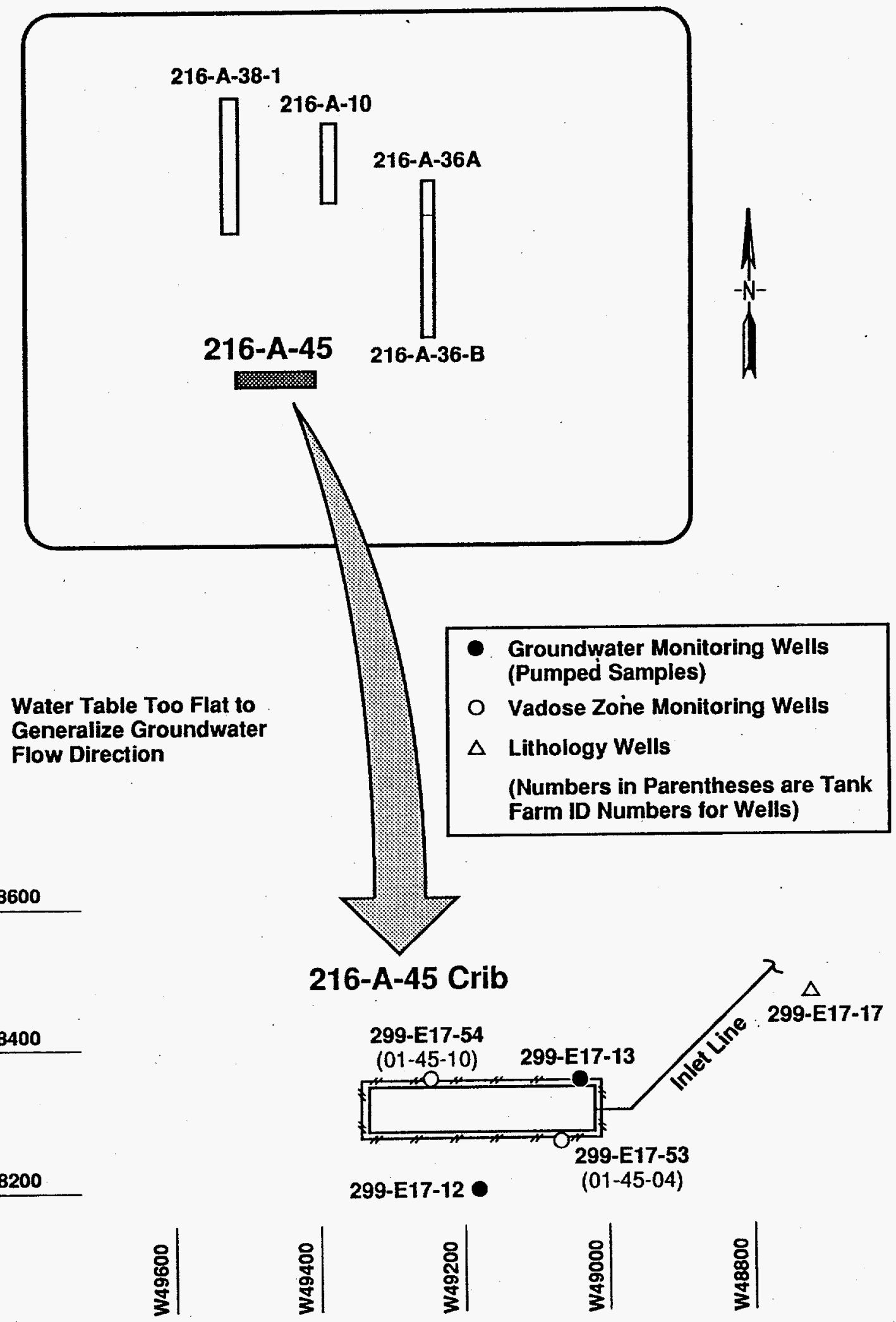


the principal source of tritium in the widespread plume that stretches across the site to the southeast. These PUREX cribs were the primary source of the tritium plume during the operating period. Tritium concentrations near the cribs were several million $\mathrm{pC} i / \mathrm{L}$, the highest concentrations observed in ground water at the Hanford Site.

The disposal of the radioactive process condensates to the $216-\mathrm{A}-45 \mathrm{Crib}$ was discontinued in mid-1989. Discharge to the 216-A-36B $\mathrm{Crib}$, which received ammonia scrubber waste containing high concentrations of tritium and many other radionuclides, was discontinued in 1987 (WHC 1990d, 1990e).

A concentration-history plot (Figure 21) for iodine-129 in wel1 2-E17-13, located immediately adjacent to the 216-A-45 Crib, shows that this mobile contaminant did not exhibit a rapid decline when use of the crib was discontinued, as was observed for tritium at the 216-A-30/216-A-37 Cribs: This may in part be related to the relatively "flat" hydraulic gradient and the significantly lower hydraulic conductivity in this area than in the area west of the grout facility and adjacent cribs (DOE-RL 1992). Contaminant concentration dynamics are discussed further in connection with concentrationhistory plots at B Plant cribs in the following subsection.

4.4.1.3 216-B-62 and 216-B-55 Cribs. The B Plant cribs received process and steam condensates that contributed appreciable amounts of fission-product radionuclides to the soil column during past-practice disposal activities (DOE-RL 1992). However, tritium in two wells at the 216-B-62 Crib (Figure 22 and 23) was the only significant contaminant occurrence identified in the Liquid Effluent Study Final Report (WHC 1990e); nevertheless, because of significant soil column loadings and a high potential for mobilization, a volume restriction was suggested if continued use of the 216-B-62 Crib was needed (WHC 1990e). Input to the crib ceased in 1986.

A tritium occurrence beneath the 216-B-62 Crib, showing an abrupt increase between 1988 and 1989, was attributed to upgradient sources associated with PUREX operations (i.e., the 216-A-45, 216-A-36B, and/or 216-A-37-1 Cribs). This conclusion is supported by similar concentrationhistory plots at other locations along the apparent northwest component of the tritium plume in the 200 East Area (see Figure 19). As previously noted, the similar concentration-time patterns (see Figure 19) at various distances strongly resemble the patterns observed for a tracer test at various distances away from the point of introduction to the aquifer. The time difference between the peaks and the corresponding distances suggests a travel time on the order of $6 \mathrm{~m} /$ day $(20 \mathrm{ft} /$ day). However, as previously indicated for iodine-129, the rate of movement in the immediate vicinity of the assumed source (216-A-45 and 216-A-36B Cribs) appears to be much slower than in the "far-field" or downgradient direction (i.e., to the northwest). The reasons for this apparent discrepancy are not clear but may be related to the change in discharge to B Pond during this period of observation (discharge to B Pond increased significantly in 1985 and then began decreasing in 1989).

The conditions described for the 200 East Area waste sites emphasize the importance of understanding contaminant plume dynamics in assessing ground water quality at RCRA and operational waste site locations downgradient of the PUREX cribs. Continued monitoring of basic indicators (tritium, 
Figure 21. Concentration-History Plot for Iodine-129 at We11 2-E17-13.

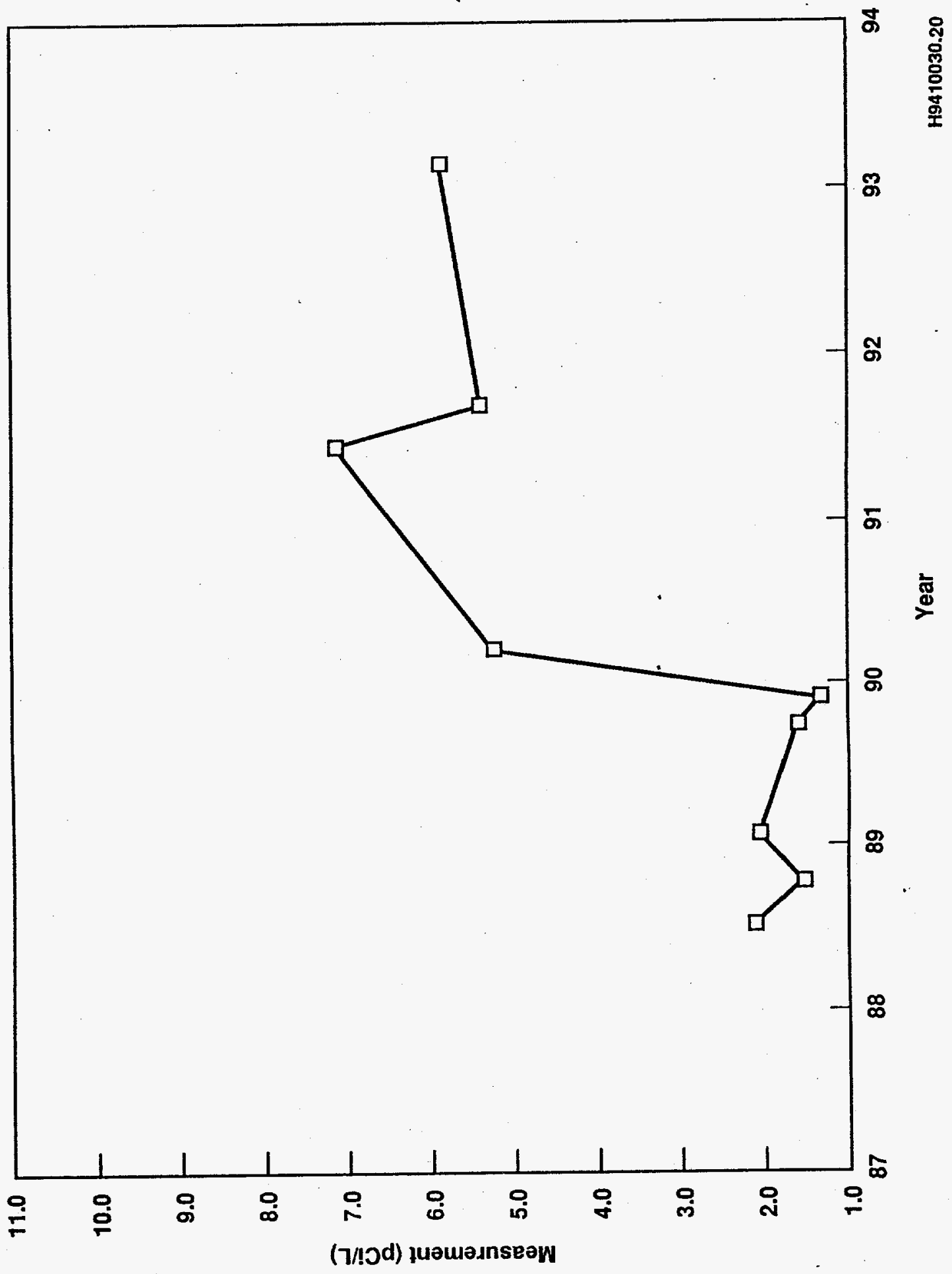


Figure 22. We11 Locations at the 216-B-62 Crib.
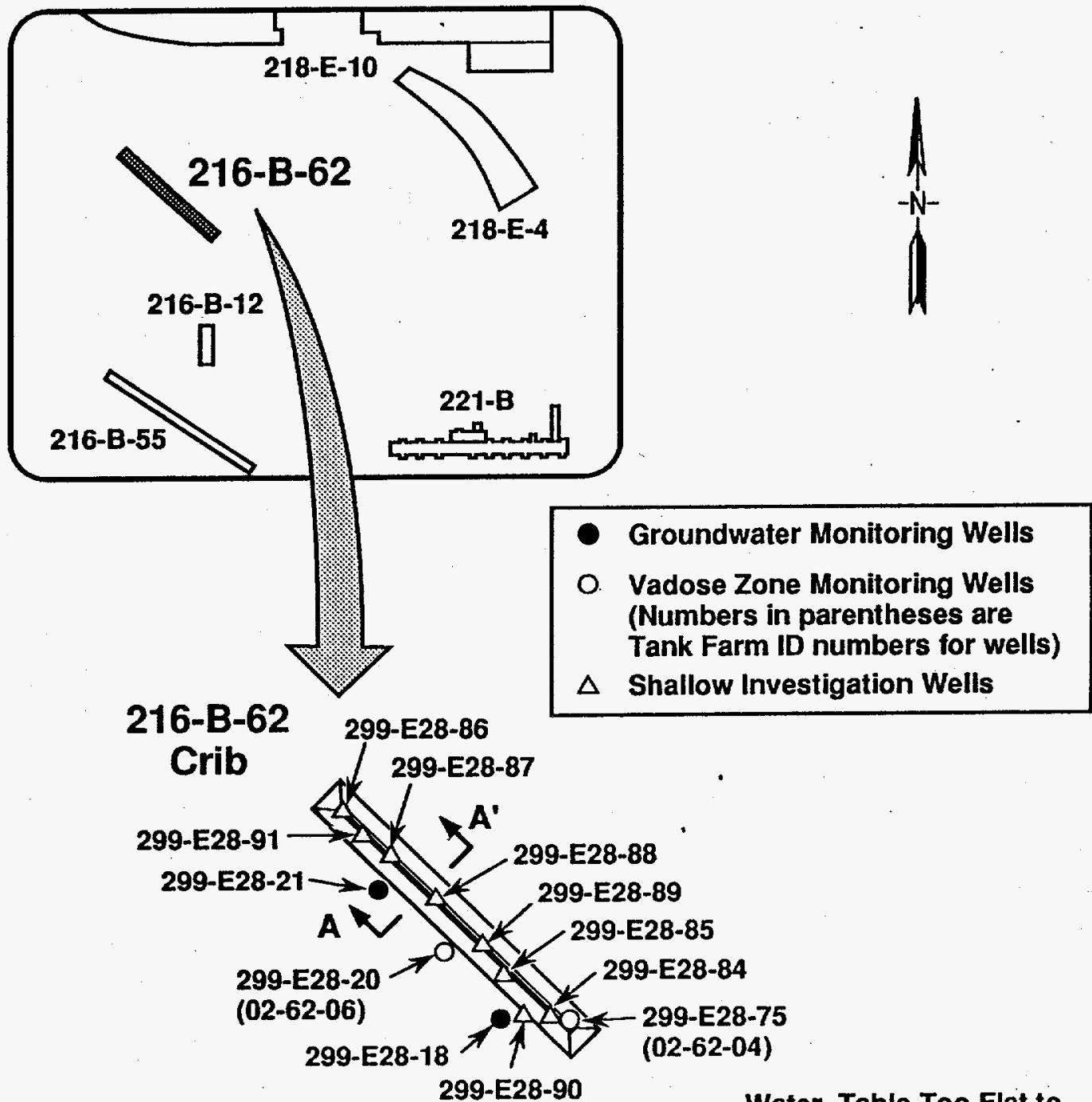

Finish Grade

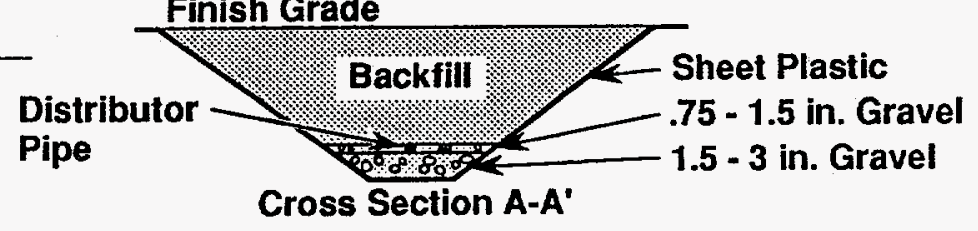

员|

8
8
ํํㄴ
3 \begin{tabular}{l}
8 \\
8 \\
8 \\
\hdashline \\
3
\end{tabular}

8
$\stackrel{8}{0}$
$\stackrel{5}{5}$
Water Table Too Flat to Generalize Groundwater Flow Direction 
Figure 23. Concentration-History Plot for Tritium at 216-B-62 Crib.

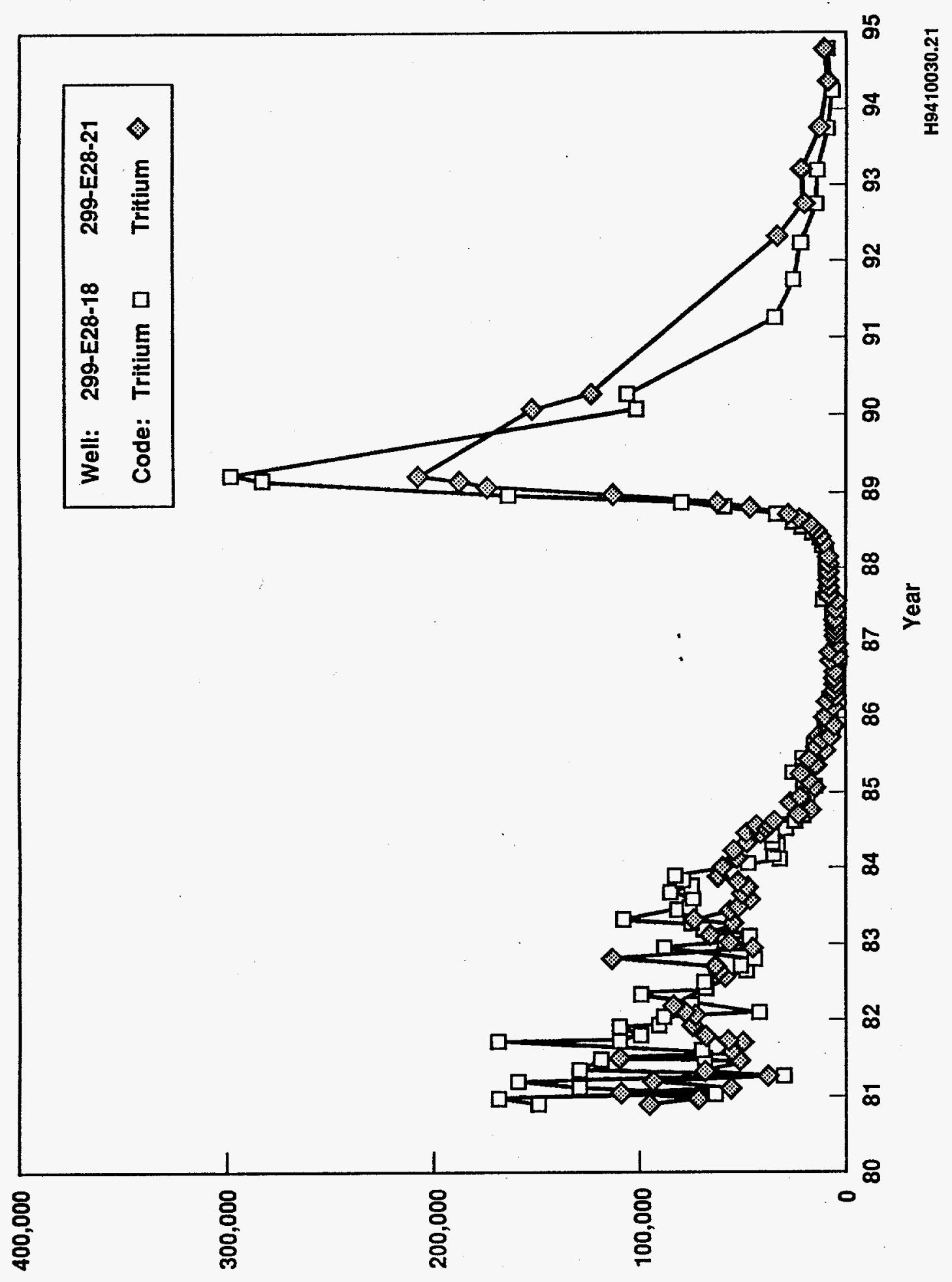

(7/!Od) juəuə..nseəw 
nitrate, gross beta) on a quarterly basis in a broad array of wells will be needed to adequately track the progress of the changes occurring because of sharply declining wastewater discharges.

\subsubsection{B Pond RCRA Ground Water Monitoring Program}

Ground water samples for the RCRA monitoring program have been collected from the network (see Figure 2) since 1988. Quarterly sampling started during the fourth quarter of 1988 and continued until the fourth quarter of 1989 . Background levels for contamination indicator parameters were established in 1990 and the 216-B-3 Pond system was scheduled to be sampled semiannually for the detection monitoring program. Total organic halogen levels exceeded the critical mean in February 1990, and confirmation of this exceedance activated the assessment monitoring program. Quarterly assessment monitoring has been carried out in accordance with the assessment monitoring plan written for the 216-B-3 Pond system (WHC 1990b).

Ground water samples have been analyzed for the interim primary and secondary drinking water standards (DWS), the ground water quality parameters, and the ground water contamination indicator parameters specified in DOE-RL (1994a). In addition, ground water samples have been analyzed for a wide range of organic and inorganic constituents. Samples from all wells in the network were analyzed at least once for the 40 Code of Federal Regulations (CFR) 264 Appendix IX 1ist of constituents and an abbreviated constituent 1ist. The results of these analyses are presented in tabular form in annual and quarterly reports (e.g., DOE-RL 1994b, 1994d). A summary of exceedances of DWSs for FY 1993 is shown in Table 3.

\subsubsection{Areas Contaminant Plumes}

Plume maps for the major ground water contaminants in the 200 Areas and associated discussion, are excerpted from the most recent annual RCRA ground water monitoring report (DOE-RL 1994b). The 200 Areas plumes are discussed collectively for: (1) perspective, and (2) because plumes from the 200 West Area either presently commingle with 200 East Area contaminant plumes, or will in the future, depending on changes in the hydrologic flow regime induced primarily by wastewater discharges to the B Pond system. Contaminant plume distribution patterns are also good indicators of the response of past ground water flow directions to changes in wastewater disposal practices. Based on current water table elevations, the inferred ground water flow directions for various starting points in the 200 Areas are shown in Figure 24 . Contaminant plumes tend to coincide with the inferred flow directions.

4.4.3.1 Order of Discussion. The plumes discussed in this section have many different sources and are associated primarily with past-practice disposal activities. Discussions of the individual plumes are ordered as follow:

- Metals--arsenic

- Anions--nitrate 
Table 3. Wells With Constituents Exceeding Drinking Water Standards by Quarter, Fiscal Year 1993.

\begin{tabular}{|c|c|c|c|c|c|}
\hline \multirow{2}{*}{ Const ituent } & \multirow{2}{*}{ DWS } & \multicolumn{4}{|c|}{ Wells Exceeding DWS by Quarter ${ }^{2}$} \\
\hline & & Oct.-Dec. 1992 & Jan.-March 1993 & April-June 1993 & July-Sept. 1993 \\
\hline $\begin{array}{l}\text { Chromium } \\
\text { (unfiltered } \\
\text { samples) }\end{array}$ & $100 \mathrm{ppb}$ & $\begin{array}{l}299-E 18-1, \\
40-40 B, 42-39 A, \\
42-39 B, 43-45\end{array}$ & $\begin{array}{l}40-39,40-40 B \\
41-40,42-39 A \\
42-39 B, 43-41 E\end{array}$ & $42-37,43-43$ & $\begin{array}{l}40-39,40-40 A \\
41-40,42-39 A, \\
42-42 B, 43-42 J\end{array}$ \\
\hline Col iform & $1 \mathrm{COL}^{2}$ & $40-40 B$ & $40-40 A, 40-40 B$ & NE & $44-39 B$ \\
\hline $\begin{array}{l}\text { Iron } \\
\text { (unfiltered } \\
\text { samples) }\end{array}$ & $300 \mathrm{ppb}$ & $\begin{array}{l}\text { All wells in } \\
\text { the network } \\
\frac{\text { except }}{43-41 G} 41-35 \text {, }\end{array}$ & $\begin{array}{l}40-36,40-39 \\
40-40 A, 40-40 B \\
41-40,42-37 \\
42-39 A, 42-39 B \\
42-40 A, 43-40 \\
43-41 E, 43-42 J \\
43-45,44-43 B\end{array}$ & $\begin{array}{l}299-E 18-1, \\
299-E 32-4, \\
40-36,40-40 A, \\
40-40 B, 41-42, \\
42-37,42-39 A \\
43-43,43-45\end{array}$ & $\begin{array}{l}\text { All wells in } \\
\text { the network } \\
\text { except } 41-35 \\
43-41 E, 43-43 \\
44-43 B\end{array}$ \\
\hline $\begin{array}{l}\text { Iron (filtered } \\
\text { samples) }\end{array}$ & $300 \mathrm{ppb}$ & $42-39 B$ & NE & NE & $44-42$ \\
\hline $\begin{array}{l}\text { Manganese } \\
\text { (unf i t tered } \\
\text { samples) }\end{array}$ & $50 \mathrm{ppb}$ & $\begin{array}{l}\text { All wells in } \\
\text { the network } \\
\frac{\text { except }}{43-45} 43-43 \text {, }\end{array}$ & $\begin{array}{l}40-36,40-39 \\
40-40 A, 42-40 A \\
40-40 B, 41-35 \\
42-37,42-39 B \\
42-40 A, 43-40 \\
43-41 G, 44-43 B\end{array}$ & $\begin{array}{l}299-E 18-1, \\
40-36,40-40 A \\
40-40 B, 41-35 \\
42-37,42-39 B \\
43-41 G\end{array}$ & $\begin{array}{l}40-39,40-40 A \\
40-40 B, 42-398 \\
42-40 A, 43-410\end{array}$ \\
\hline $\begin{array}{l}\text { Manganese } \\
\text { (filtered samples) }\end{array}$ & $50 \mathrm{ppb}$ & $\begin{array}{l}40-36,40-40 A \\
40-40 B, 41-35 \\
42-37,42-39 B \\
43-41 G\end{array}$ & $\begin{array}{l}40-36,40-40 A \\
40-40 B, 41-35 \\
42-37,42-39 B \\
42-40 A, 43-40 \\
43-41 G, 44-43 B\end{array}$ & $\begin{array}{l}299-E 18-1, \\
40-36,40-40 A \\
40-40 B, 41-35, \\
42-37,42-39 B \\
43-41 G\end{array}$ & $\begin{array}{l}40-40 A, 40-40 B \\
42-39 B, 43-41 G\end{array}$ \\
\hline Nitrate & $45 \mathrm{ppm}$ & $43-43$ & NE & NE & NE \\
\hline Tritium & $\begin{array}{l}2.0 \mathrm{E} 4 \\
\mathrm{PCi} / \mathrm{L}\end{array}$ & $\begin{array}{l}42-39 A, \quad 42-39 B \\
43-41 G\end{array}$ & $\begin{array}{l}41-40,42-39 A \\
42-39 B, 42-42 B \\
43-40,43-41 E \\
43-41 F, 43-41 G \\
44-43 B\end{array}$ & $\begin{array}{l}41-42,42-39 A \\
42-39 B, 43-41 G\end{array}$ & $\begin{array}{l}41-40,41-42 \\
42-39 A, 42-39 B \\
42-42 B, 43-40 \\
43-41 E, 43-41 F \\
43-41 G\end{array}$ \\
\hline Turbidity & 1 NTU & $\begin{array}{l}299-E 18-1, \\
40-40 A, 40-40 B \\
42-39 A\end{array}$ & $\begin{array}{l}40-40 B, 41-40 \\
42-39 A\end{array}$ & $\begin{array}{l}299-E 18-1, \\
40-36,40-40 B \\
41-35,41-42, \\
42-37,42-39 A\end{array}$ & $\begin{array}{l}\text { All wells in } \\
\text { the network } \\
\text { except } 42-41 \\
33-43,44-42\end{array}$ \\
\hline $\mathrm{pH}<6.5$ & 6.5 & NE & NE & $42-40 A$ & NE \\
\hline $\mathrm{pH}>8.5$ & 8.5 & $\begin{array}{l}40-39,41-40 \\
43-41 E, 43-416\end{array}$ & $43-41 E, 43-41 G$ & $43-41 E$ & NE \\
\hline
\end{tabular}

${ }^{1}$ All well designations prefixed by $699-$, unless indicated otherwise.

${ }^{2}$ Coliform colonies per 100 milliliters.

DWS = drinking water standards.

NE = constituent did not exceed DWS in any wells during this quarter.

NTU = nephelometric turbidity unit . 
WHC-EP-0813

Figure 24. Ground Water Flow Paths.

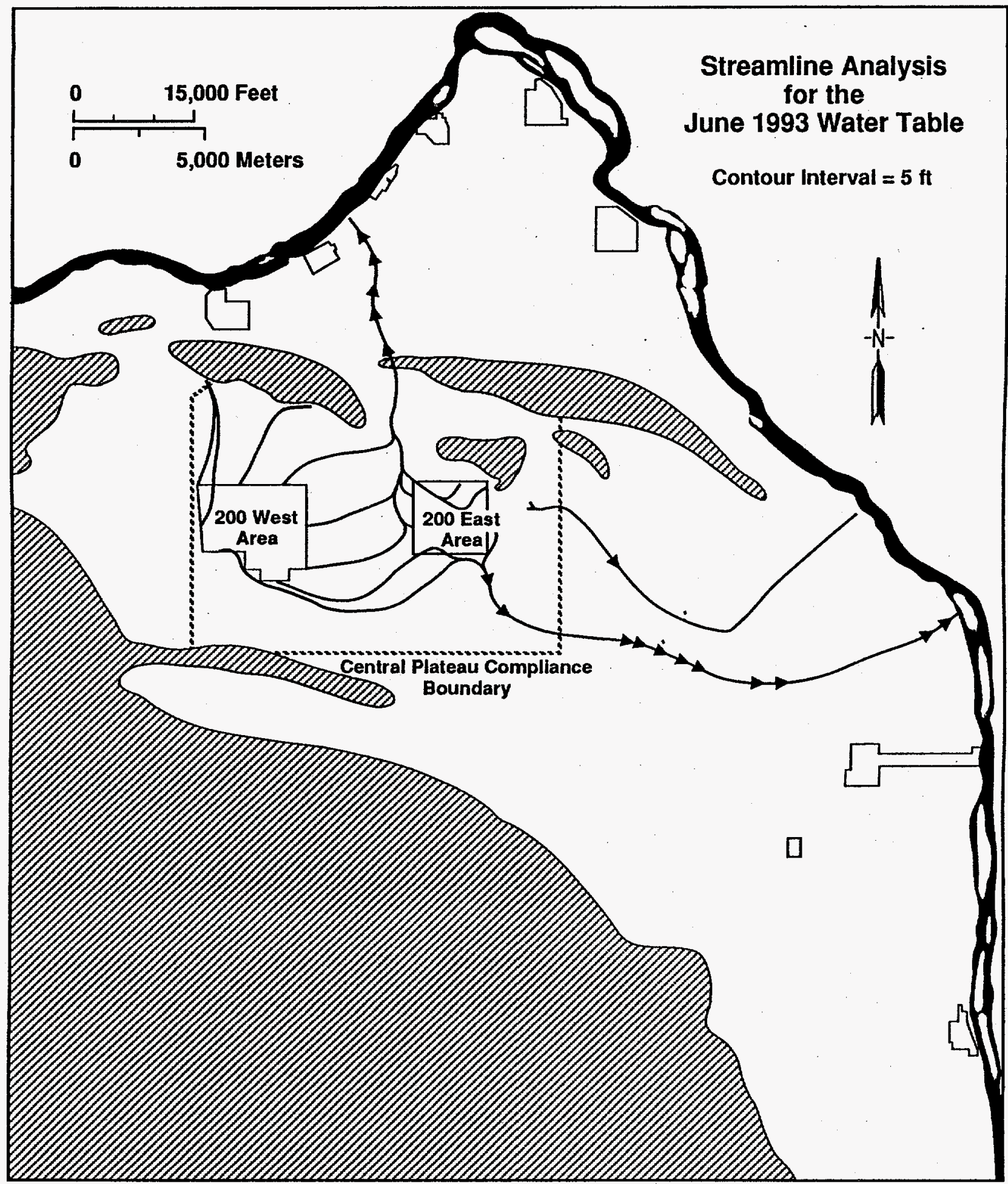

H9410030.17 
WHC-EP-0813

- Tritium

- Beta-emitting radionuclides--gross beta, technetium-99, and iodine-129.

- Alpha-emitting radionuclides--gross alpha.

Additional contaminants have been identified and mapped in the Groundwater Field Characterization Report for the 200 Aggregate Area Management Study (WHC 1993a).

The primary objective of each contaminant map is to illustrate the extent of the plume that exceeds the most stringent regulatory standard that is applicable to the contaminant. The standards have been noted in the legend for each map. In some cases, the detection limit (DL) or minimum detectable concentration is greater than the most stringent standard (e.g., arsenic). In each of these cases, the minimum isopleth has been selected at a value close to the DL. Plumes that are defined by only one well are identified in discussions as potential plumes.

To illustrate the potential extent of some contaminant plumes (e.g., tritium and technetium-99), an additional contour that is less than the most stringent regulatory standard has been added. When such a contour is included, a dashed line has been used to help distinguish it from the standard-exceeding contours.

\subsubsection{Individual Plume Descriptions.}

4.4.3.2.1 Metals--Arsenic (filtered). The Washington Water Quality Standard (WWQS) for arsenic is $0.05 \mathrm{ppb}$ (WAC 173-200). This value is two orders of magnitude less than the $\mathrm{DL}(5 \mathrm{ppb})$, and three orders of magnitude more stringent than the DWS and maximum contaminant level of $50 \mathrm{ppb}$. Arsenic contamination is illustrated in Figure 25 . The only regulatory standard that is exceeded in any of the wells in the 200 Areas is the WWQS.

A large plume of slightly elevated arsenic contamination is present beneath the northeastern half of the 200 East Area. Average detections within the plume range between 6 and $15 \mathrm{ppb}$. Natural background for the Hanford Site was reported as $3.9 \pm 2.4 ; 6.7 \pm 3.7$, and $<5 \mu \mathrm{g} / \mathrm{L}$, respectively, for three different data sources. A provisional threshold value (upper $95 \%$ confidence level) of $10 \mu \mathrm{g} / \mathrm{L}$ was recommended (Johnson 1993, Appendix A). The arsenic was probably present as a co-contaminant in chemical waste previously discharged to adjacent cribs and ditches (e.g., the 216-A-29 Ditch and the 216-A-37. or 216-A-30 (ribs).

4.4.3.2.2 Anions--Nitrate. Nitrate contamination $(>45,000 \mathrm{ppb})$ is widespread in the 200 West Area with smaller plumes in and north of the 200 East Area (Figure 26). The contamination from the 200 West Area has been transported far beyond the eastern boundary of the area. Insufficient wells have been installed in this area immediately west of the 200 East Area to assess the potential for this plume to have reached the border of the 200 East Area. The same problem exists in the interpretation of the extent of tritium contamination (Section 4.4.3.2.3). 


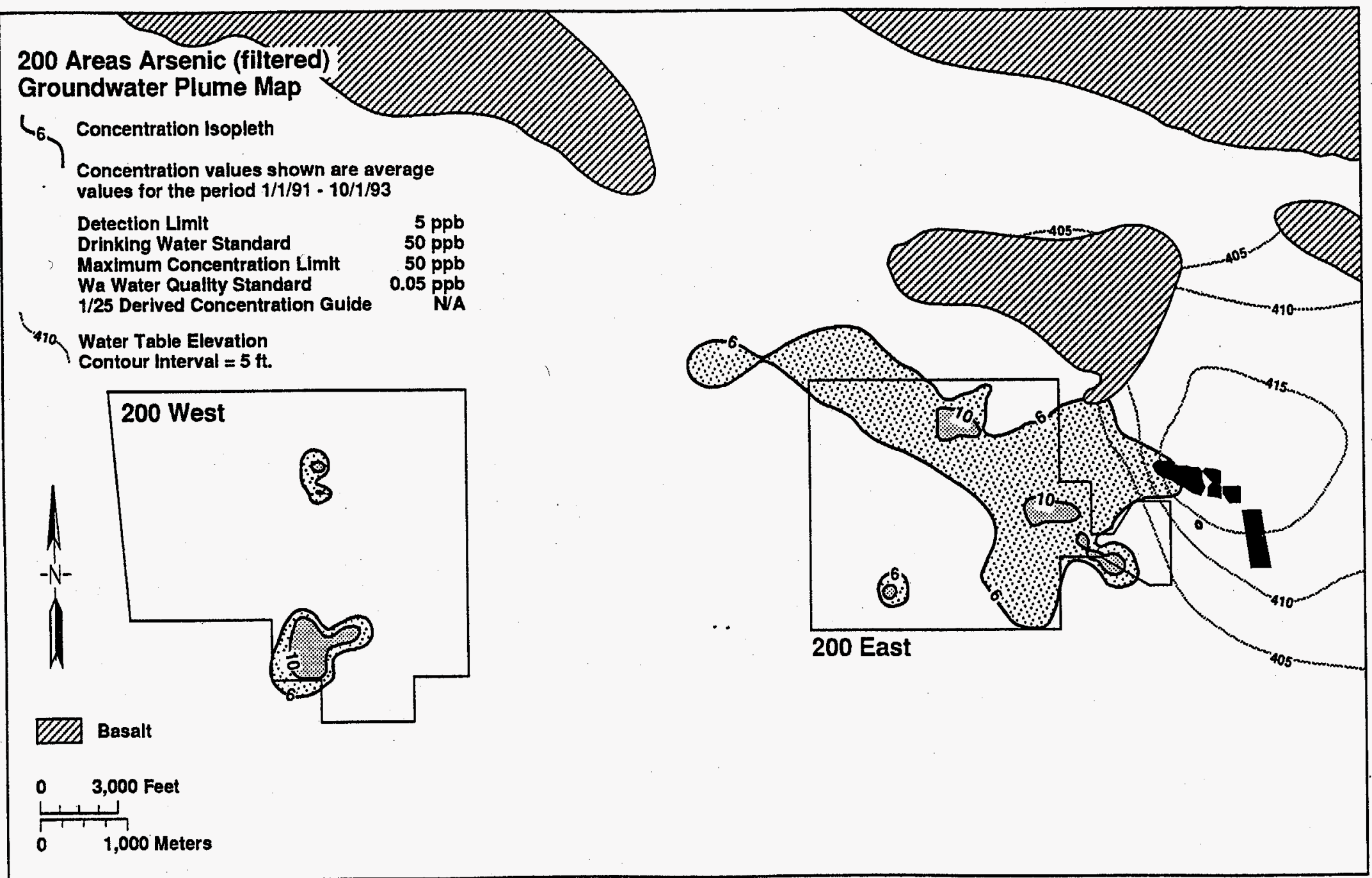

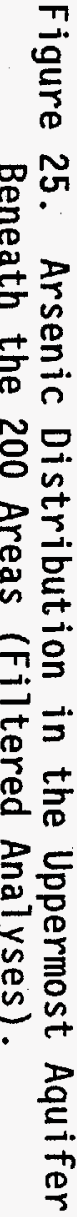




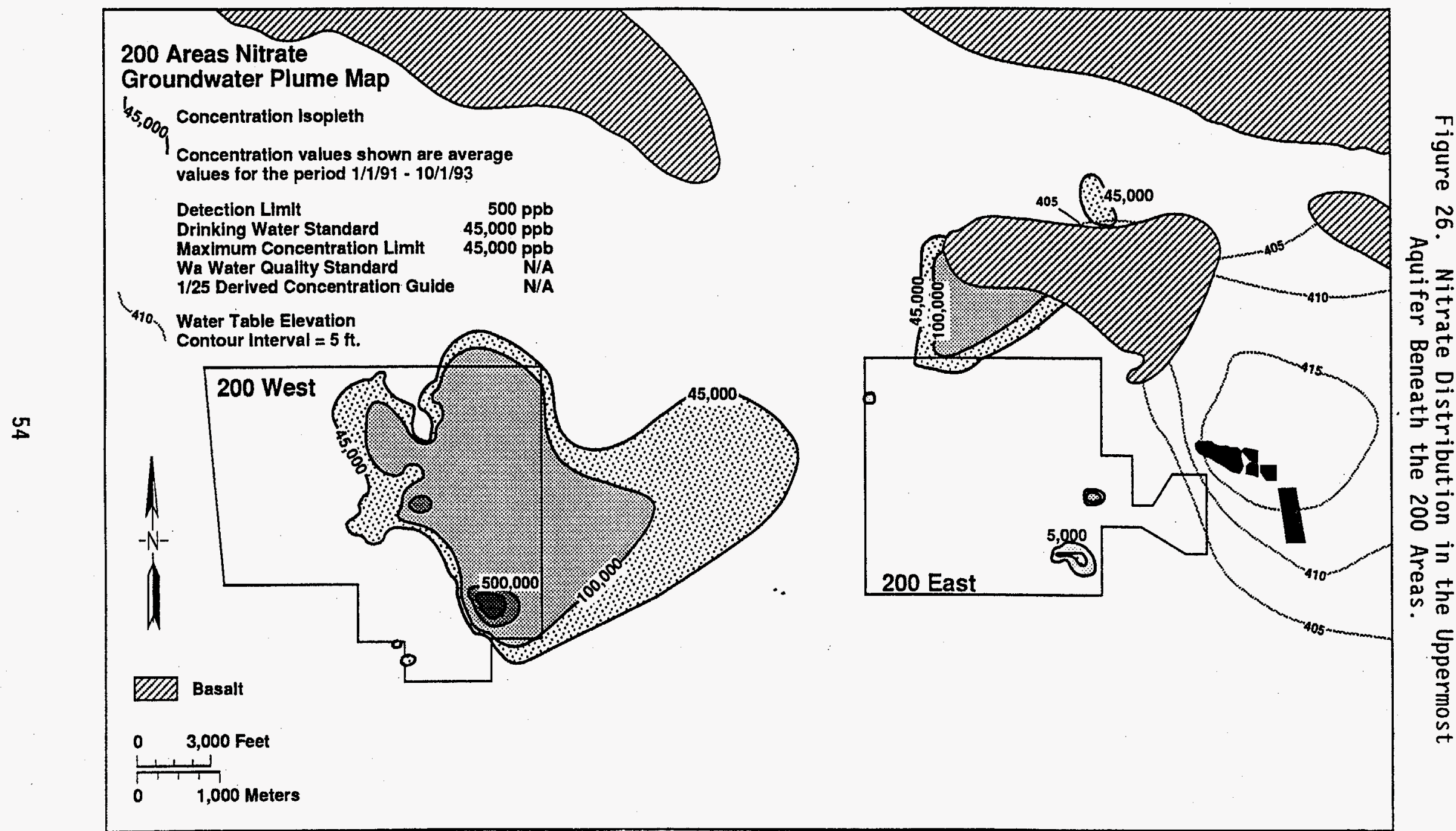


The highest average concentration of nitrate in wells in the eastern half of the 200 Areas occurs in well 6-50-53A $(440,000 \mathrm{ppb})$, which is located just to the north of the 200 East Area. The contamination appears to be the result of the disposal of scavenged uranium recovery waste to the BY cribs in the 200 East Area during the 1950's. Two plumes located in the southeastern corner of the 200 East Area are centered on wells that monitor facilities that have at some time received effluent from PUREX Plant or the 242-A Evaporator. The maximum average contamination occurs in we11 299-E25-13 (293,000 ppb). A one-well potential contaminant plume is indicated in the northwestern corner of the 200 East Area. A two-well plume is defined just north of the basalt subcrop (hachured area northeast of the 200 East Area) in the vicinity of the decommissioned Gable Mountain Pond. The contaminant levels are just barely above the DWS.

\subsection{Tritium.}

Tritium is discussed separately from the other beta-emitting radionuclides because (1) it is an extremely weak beta emitter and (2) its unique chemistry makes it the most mobile of the radionuclides and is therefore an excellent tracer. Tritium contamination (DWS of 20,000 pCi/L) extends beneath large portions of the 200 Areas (Figure 27).

A large plume of contamination originates in the southwest corner of the 200 West Area, extends eastward towards the 200 East Area, and may intercept plumes beneath the 200 East Area. There is a lack of well control to define the relationship of the plumes. The maximum average tritium concentration in the plume is in well 699-35-66 $(856,750 \mathrm{pCi} / \mathrm{L})$.

Tritium contamination extends diagonally from the northwest to the southeast beneath the 200 East Area. Highest average concentrations are found in the southeast corner of the 200 East Area in wells monitoring disposal facilities associated with the PUREX Facility. A discussion of the potential for $B$ Pond to be a hydraulic driver influencing contaminant distribution is presented in the Westinghouse Hanford Company Operational Groundwater Status Report, 1990-1992 (WHC 1993b). The highest average concentrations in the plume are found in well 2-E17-20 $(2,430,000 \mathrm{pCi} / \mathrm{L})$. A plume of contamination has also moved off to the northwest of the 200 East Area and is indicated by the $20,000-p C i / L$ contour that appears in the north-central portion of Figure 27.

\subsection{Beta-emitting Radionuclides.}

The general distribution of beta-emitting radionuclides is presented in Figure 28. There is a DWS- and WWQS-equivalent standard of $50 \mathrm{pCi} / \mathrm{L}$ for gross beta.

The largest of the beta plumes in the 200 East Area (see Figure 28) extends north from the 200 East Area. At least two contaminant sources contributed to the beta contamination, the BY cribs and the Gable Mountain Pond. The highest average concentration in the plume occurs in we11 6-50-53A $(1,692 \mathrm{pCi} / \mathrm{L})$. This well is the locus for other elevated contaminant concentrations (nitrate and cyanide). Technetium-99 (Figure 29), cobalt-60, and strontium-90 are the primary beta emitters contributing to the plume 


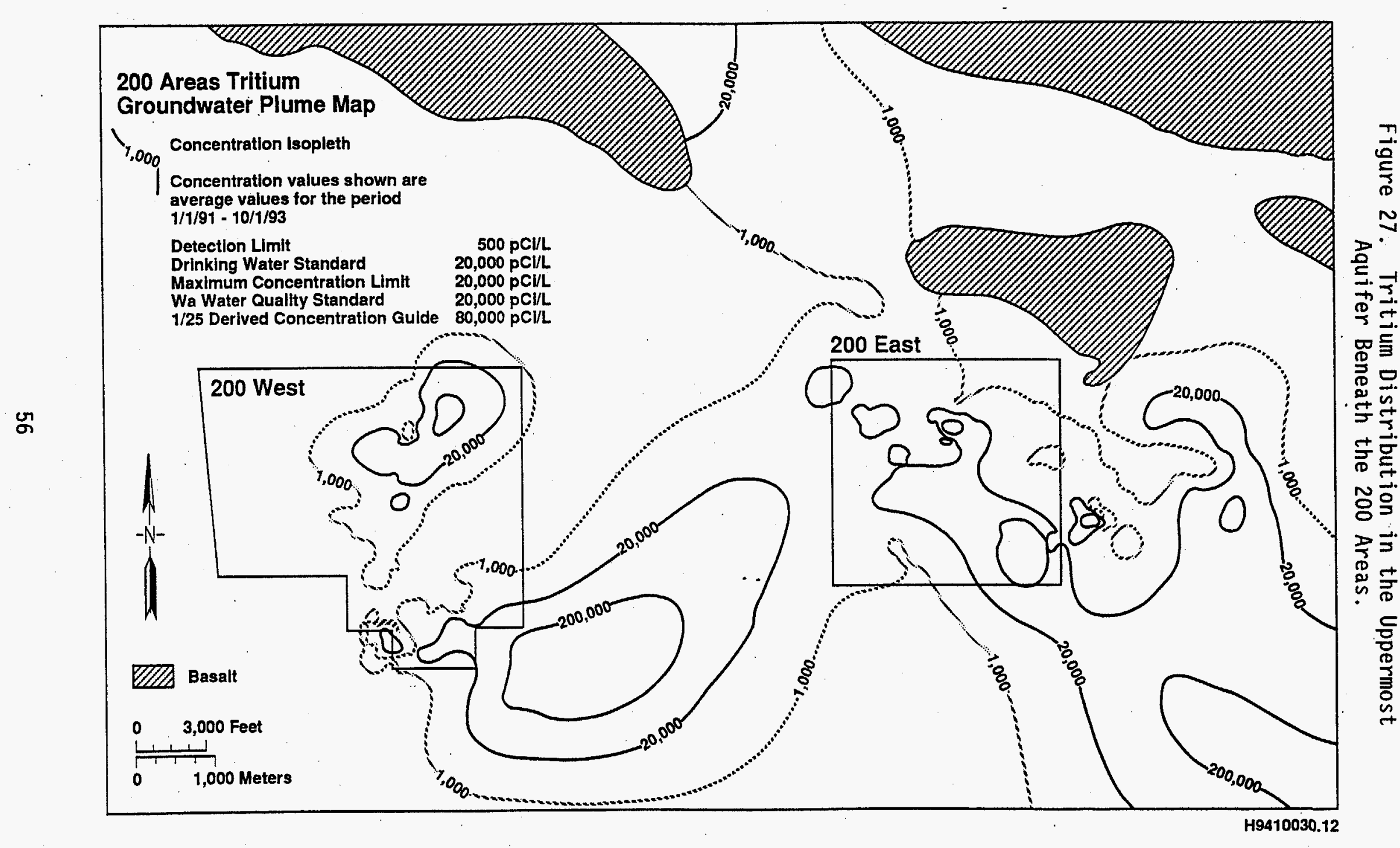




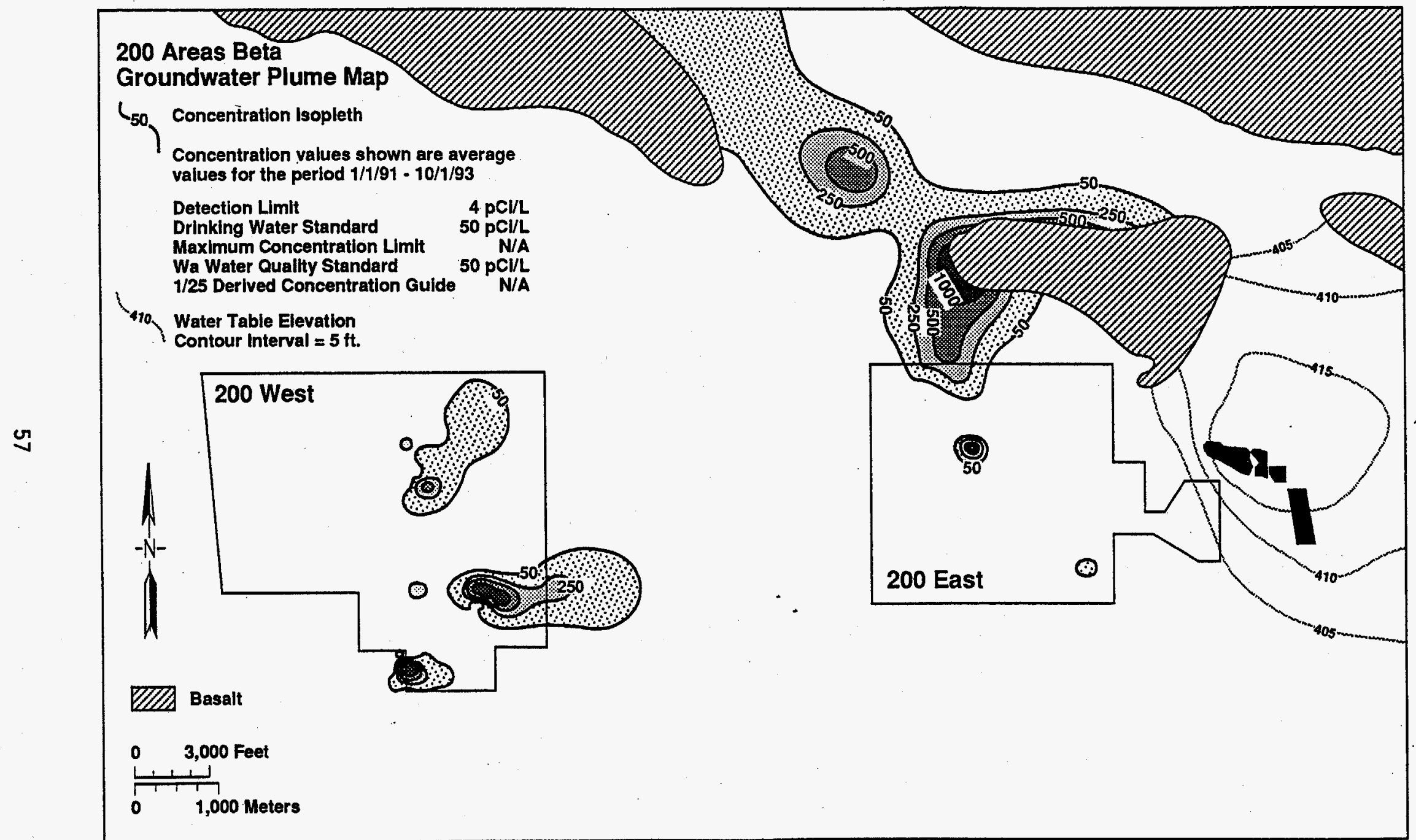

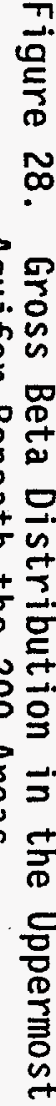




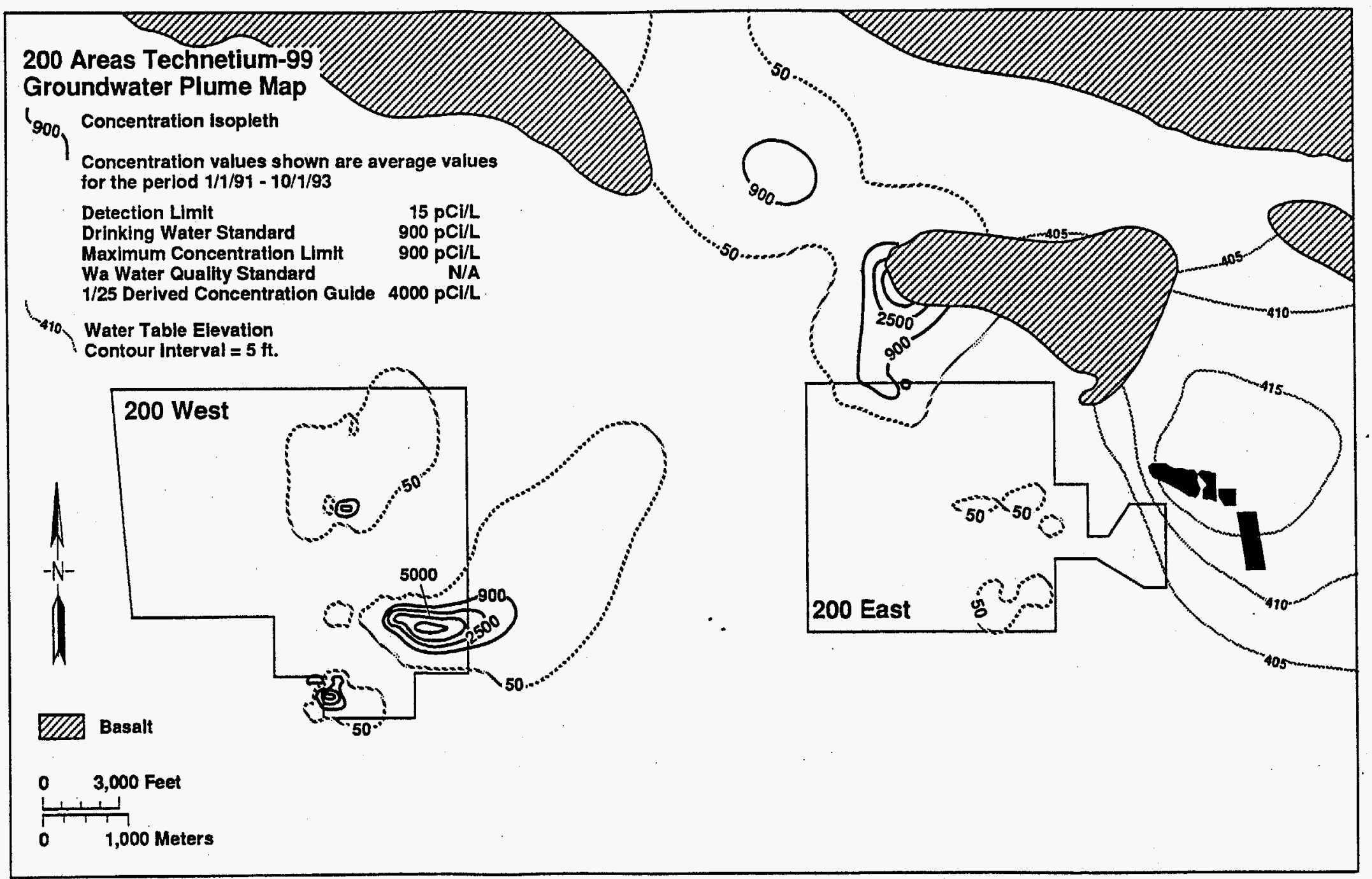

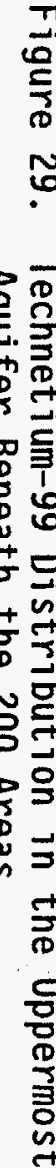

H9410030.10 
distribution. A tightly constrained beta plume located in the north-central portion of the 200 East Area is associated with contamination in the vicinity of the B-5 reverse well (strontium-90 and cesium-137). The highest average gross beta concentration in this plume is in well 2-E28-23 $(19,500 \mathrm{pCi} / \mathrm{L})$. The third plume beneath the 200 East Area is in the southeast corner in wells that monitor PUREX-related disposal facilities. Technetium-99 and strontium-90 are the primary contributors to beta contamination.

Technetium-99. The DWS for technetium-99 is significantly higher than the minimum detectable concentration (900 versus $15 \mathrm{pCi} / \mathrm{L}$ ).

In the vicinity of the 200 East Area a plume (see Figure 29) extending northward from the area is centered on well 699-50-53A $(5,198 \mathrm{pC} i / L)$, the same well with the maximum average values for cyanide and cobalt-60. The plume originates from beneath the BY crib area along the northern margin of the 200 East Area. A single-well plume to the northwest of the main plume is centered on well 6-55-57. The well al so has elevated cobalt-60.

Iodine-129. The minimum detectable concentration for iodine-129 is equivalent to the DWS of $1 \mathrm{pCi} / \mathrm{L}$. The minimum isopleth contoured in Figure 30 is equal to this value.

Nearly the entire central portion of 200 East Area is underlain by iodine-129-contaminated ground water. The highest average concentrations are found in wells in the southeastern corner of the area, the highest being in well 2-E17-1 (17 pCi/L). The wells monitor PUREX disposal facilities. Another plume extends out of the mapped area to the southeast and is large and very poorly constrained. It vaguely mimics the tritium contaminant plume that extends southeasterly from the 200 East Area and out of the mapped area. The highest average value in this plume is $6 \mathrm{pCi} / \mathrm{L}$.

4.4.3.2.5 Alpha-emitting Radionuclides. Gross alpha contamination in the 200 Areas is shown in Figure 31. The DWS and WWQS for gross alpha is $15 \mathrm{pCi} / \mathrm{L}$. The two alpha-emitting radionuclides that are responsible for the contamination are uranium and plutonium.

Two plumes and one one-well potential plume of alpha contamination are present beneath the 200 West Area. The plumes coincide with mapped uranium contamination. The largest plume has migrated beyond the eastern boundary of the area. Maximum average concentration within the plume exceeds $1,616 \mathrm{pCi} / \mathrm{L}$. Alpha contamination in the plume is connected with mobilization of uranium beneath the 216-U-1 and 216-U-2 Cribs, and possibly leakage from an effluent transfer line to the 216-U-8 and 216-U-12 cribs. The plume just to the west has the next highest average contamination (207 pCi/L, well 299-W11-14) and appears to be remnant contamination from the 216-U-10 Pond.

A single plume is identified beneath the boundaries to the 200 East Area. Plutonium contamination beneath the $B 5$ reverse well is the alpha-emitting radionuclide responsible for the plume. The highest average contamination is in we11 299-E28-25 (43 pCi/L). 


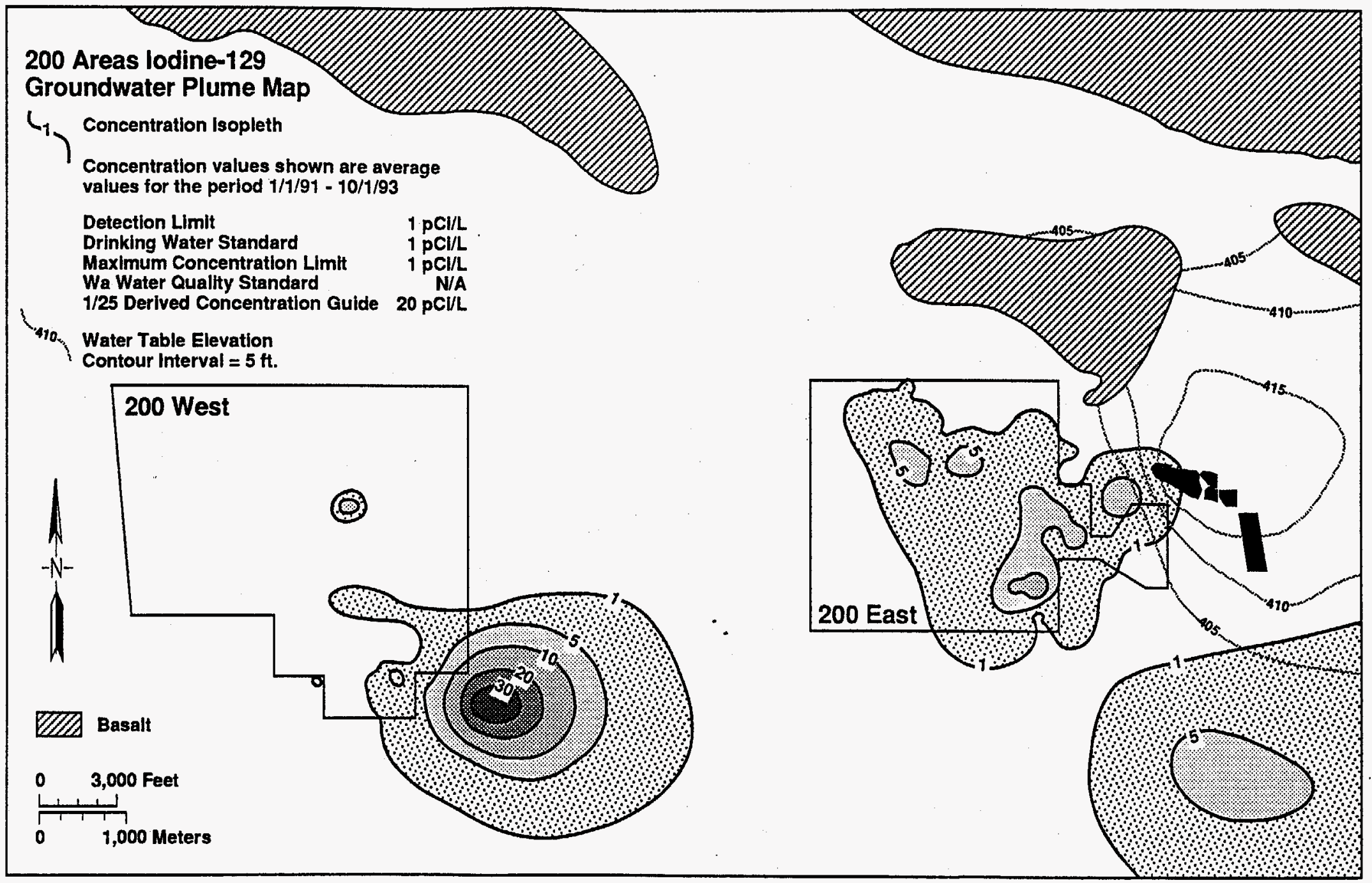

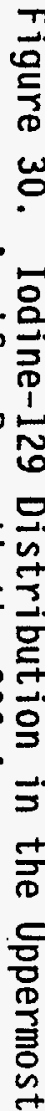

H9410030.9 


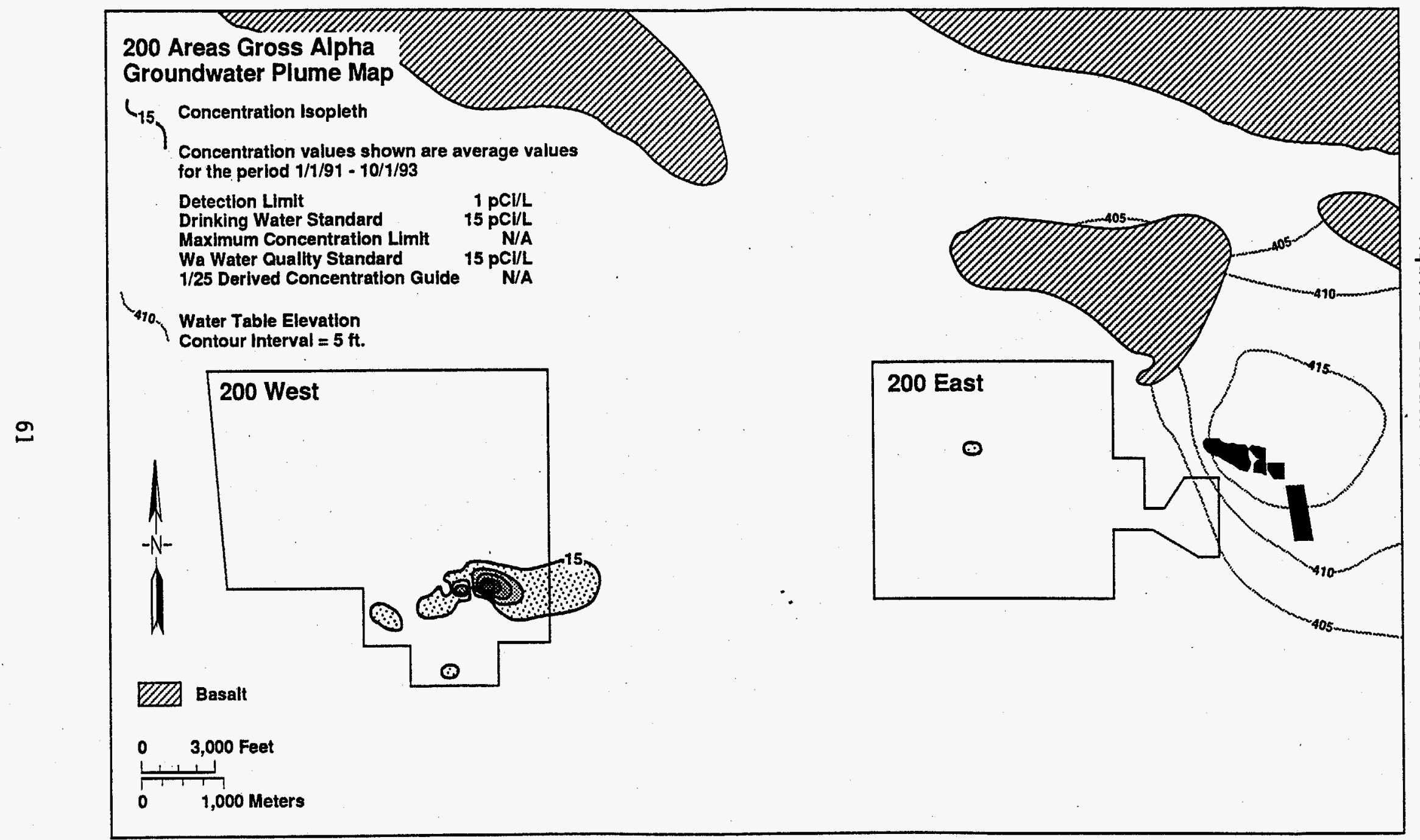

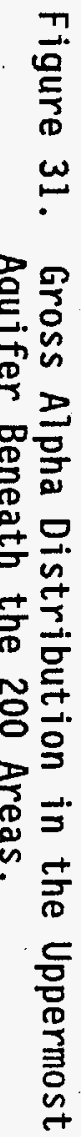


4.4.3.3 Changes in Contaminant Plume Movement. The shape and extent of the large ground water mound (see Figure 15) and the contaminant plume distribution patterns, clearly illustrate the influence of discharges to the $B$ Pond system on ground water movement in the vicinity of the 200 East Area. Because the magnitude of the mound is diminishing in response to decreased discharges, the rate of ground water movement should also decline. The direction(s) of flow may also change in the future. For example, movement through Gable Gap may disappear as discharge is terminated or significantly reduced. Under current conditions, the groundwater mound appears to control contaminant plume movement through Gable Gap as well as to the south and southeast. Groundwater modeling, as presented in the following section, is needed to predict the magnitude and extent of changes caused by both near-term and long-term changes in planned discharges. 


\subsection{MODELING OF THE GROUND WATER SYSTEM}

To assess the impacts of continued operation of the 3 C Expansion Pond, a computer model was used to simulate the Hanford ground water flow system. The modeling process begins with a conceptual model of the geohydrologic system, which is basically a picture of the geology and hydrology as understood and applied in the analysis. The conceptual model is then translated into a mathematical model via a computer code. This step involves the establishment of a grid and the estimation of geohydrologic properties, source terms, and boundary and initial conditions that portray the essential elements of the conceptual model.

Based on the previous discussion of existing data, the potential primary impacts of continued discharge involve:

- Mobilization of residual contaminants in the lower vadose zone caused by the localized rise in the water table (Figure 32)

- Alteration of existing contaminant plumes with a resulting adverse impact.

The model starts with the water table for December 1992 and simulates the water table response to the recorded effluent disposal for 1993 and the first 7 months of 1994 and the estimated effluent disposal for the period August 1994 through October 1997.

\subsection{CONCEPTUAL MODEL}

The 216-B-3 Pond system disposes wastewater to the unconfined aquifer in the sediments above basalt, although locally there is some semi-confinement in the region of the pond system.

Water table maps for the past several years helped establish the domain of influence as exhibited in Figure 33. The model domain is rectangular with distances of $13,200 \mathrm{~m}(43,307 \mathrm{ft})$ in the east-west direction and 9,000 $\mathrm{m}$ $(29,528 \mathrm{ft})$ in the north-south direction, yielding an area of $11,880 \mathrm{ha}$ $(29,355$ acres $)$.

The geologic portion of the conceptual model is based on the discussion presented in Sections 4.1 and 4.2. The base of the unconfined aquifer is taken as the top of the lower mud unit in the Ringold Formation where it exists, otherwise the top of basalt is taken as the bottom of the aquifer. In places where the water table is at or below the top of the lower mud unit, the bottom of the aquifer is taken as the top of the basalt. The aquifer is considered to be composed of Hanford formation materials overlying the Ringold sediments. 


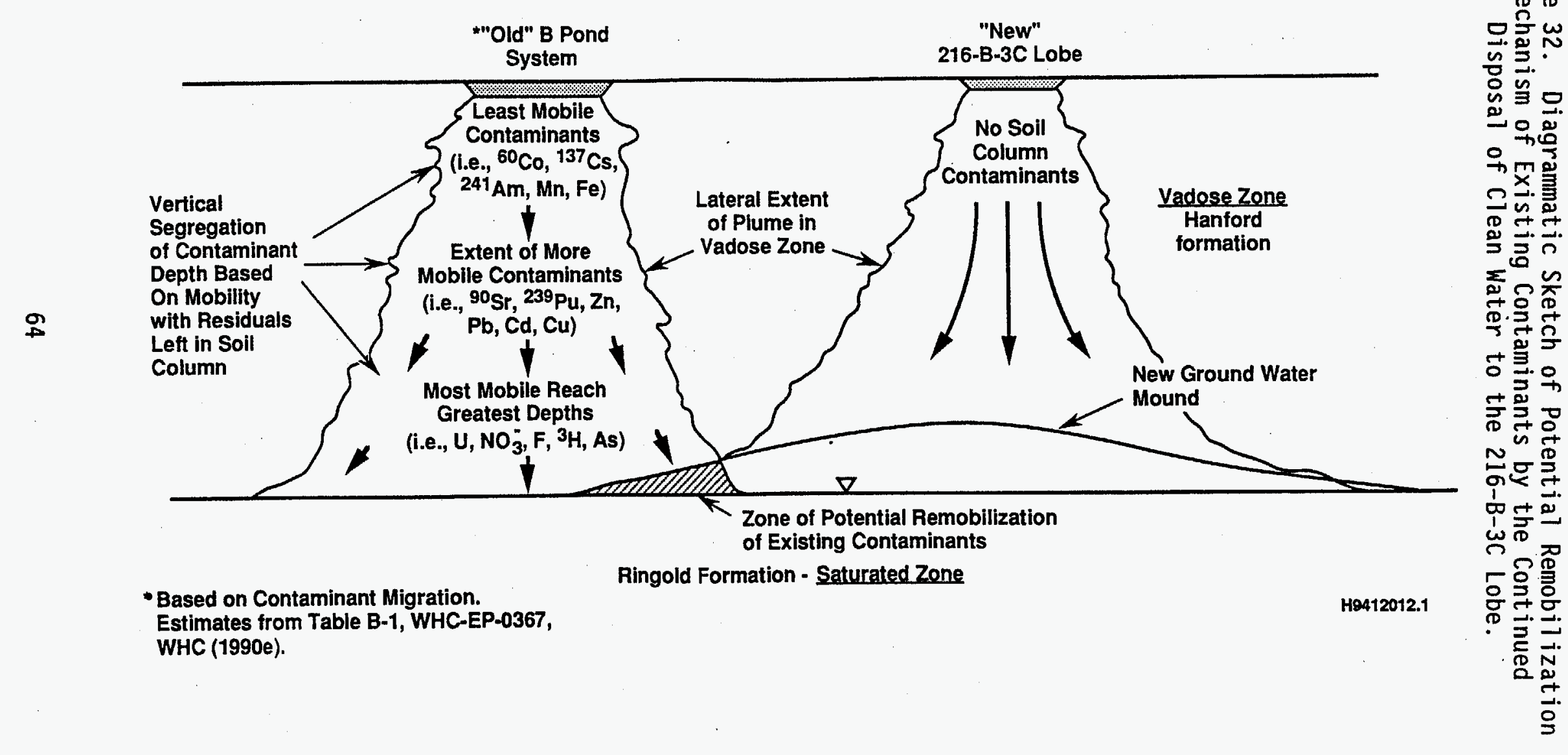


WHC-EP-0813

Figure 33. Model Domain of the 216-B-3 Pond System.

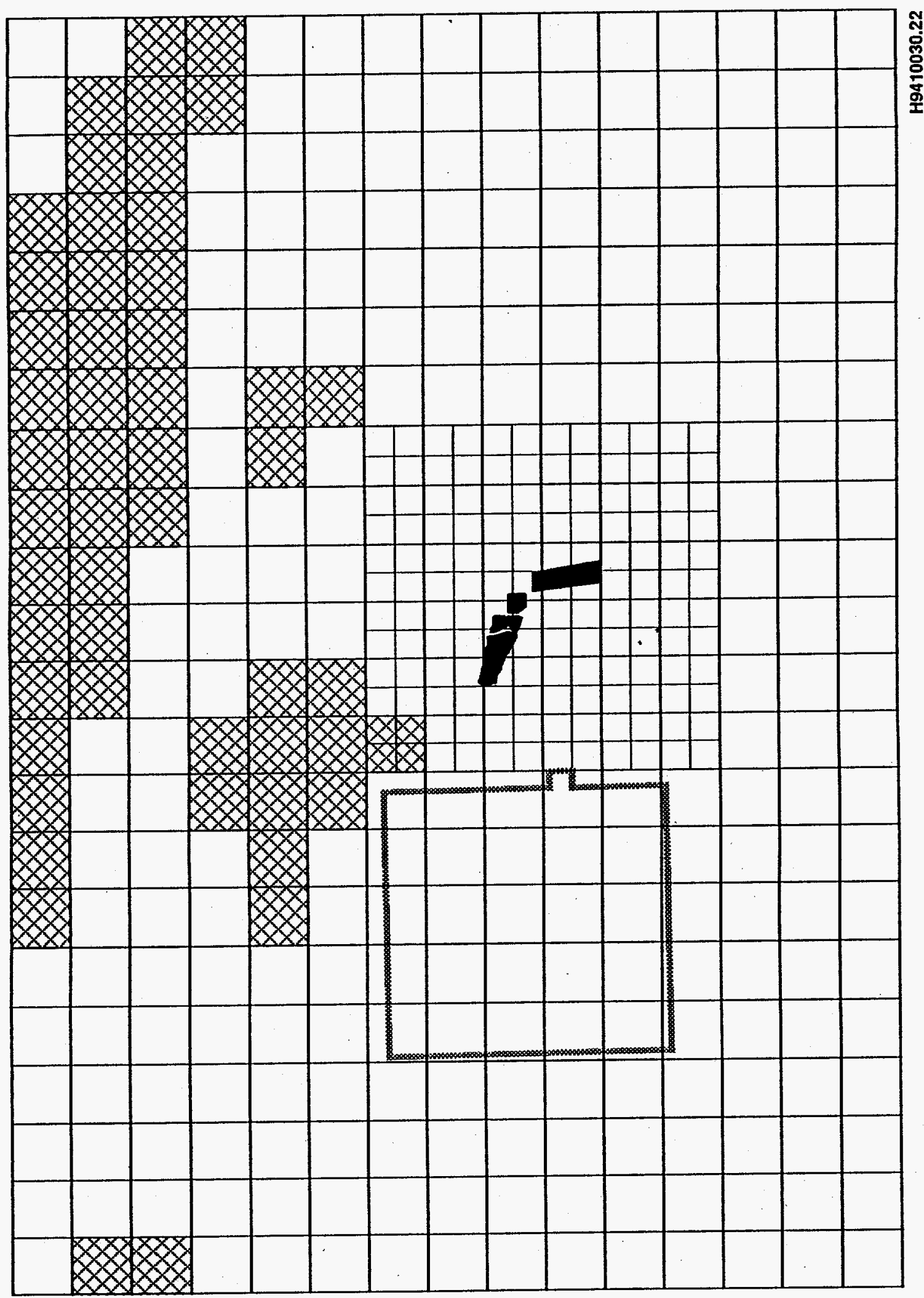


The geohydrologic conceptual model is represented by a high-conductivity layer (Hanford formation) over a lower-conductivity layer (Ringold Formation). The hydraulic conductivities were estimated based on point aquifer test results that were then extrapolated with the use of Earth Vision ${ }^{1}$ software.

The time domain for modeling is the period beginning in January 1993 and going to October 1997. Monthly effluent volumes for January 1993 through August 1994 were obtained from recorded flows, while volumes for the following months were estimated discharges. Table 4 is a listing of the monthly flows that served as the source terms.

A recent review of water level measurements in the area east of the 200 East Area revealed a rise of several feet in the water table in the spring of 1994. Information collected to date suggests that this rise is in response to the decommissioning of the main pond, 216-B-3, and the first lobe, 216-B-3A, about March 1, 1994. When these ponds were in operation they not only disposed a large volume of water, but provided a lag effect because water had to flow through these ponds to reach the main lobe. Now that effluent goes directly to the third lobe, 216-B-3C, a larger volume of water reaches that lobe faster, with an attendant rise in the water table. Inputs of effluents to the model were set up to accommodate this change in the distribution of water to the subsurface (see Table 4).

\subsection{COMPUTER CODE}

The B Pond system model is a subregion of the sitewide ground water mode1 that is being developed presently. The code selected for the sitewide model is the finite element Variably Saturated Analysis Model in 3-Dimensions with Preconditioned Conjugate Gradient Matrix Solver (VAM3DCG) devised by Dr. Peter Huyakorn and his staff at HydroGeoLogic, Inc., Herndon, Virginia. This code was selected because of its capability to deal with water table conditions and to make use of transitional elements for refining the grid where appropriate. The code was devised for the application of hexahedral brick elements so that influence functions could be incorporated to make the code more robust and efficient.

\subsection{MATHEMATICAL MODEL}

The VAM3DCG finite element code employs Galerkin and upstream weighted residual procedures for solving the flow and transport equations. Six layers of elements were chosen for the model, with one to three layers (depending on the thickness) representing the high-conductivity Hanford formation and the element layers beneath representing the lower-conductivity Ringold unit $E$. Transitional elements were employed in 36 elements around the 216-B-3 Pond system to reduce the grid to $300-\mathrm{m}$ by $300-\mathrm{m}$ elements instead of $600-\mathrm{m}$ by $600-\mathrm{m}$ elements. Therefore, the resulting grid consisted of seven layers of 488 nodes per layer, for a total of 3,416 nodes; and six layers of 438 elements per layer for a total of 2,628 elements (see Figure 33).

\footnotetext{
${ }^{1}$ Earth Vision is a registered trademark of Dynamic Graphics, Inc.
} 
WHC-EP-0813

Table 4. Effluent Disposal to the

216-B-3 Pond Syștem. (2 sheets)

\begin{tabular}{|c|c|c|}
\hline Month & $\begin{array}{l}\text { Effluent volume } \\
(\mathrm{L} / \text { month })\end{array}$ & $\begin{array}{l}\text { Receiving disposal } \\
\text { facility }\end{array}$ \\
\hline \multicolumn{3}{|c|}{1993} \\
\hline January & $4.79 E+08$ & $\begin{array}{l}\text { 216-B-3, } 216-B-3 A, \\
216-B-3 C \text { Expansion Ponds }\end{array}$ \\
\hline February & $3.98 E+08$ & $\begin{array}{l}\text { 216-B-3, } 216-B-3 A, \\
216-B-3 C \text { Expansion Ponds }\end{array}$ \\
\hline March & $3.18 E+08$ & $\begin{array}{l}\text { 216-B-3, 216-B-3A, } \\
216-B-3 C \text { Expansion Ponds }\end{array}$ \\
\hline April & $3.54 E+08$ & $\begin{array}{l}216-B-3,216-B-3 A, \\
216-B-3 C \text { Expansion Ponds }\end{array}$ \\
\hline May & $4.66 E+08$ & $\begin{array}{l}\text { 216-B-3, 216-B-3A, } \\
216-B-3 C \text { Expansion Ponds }\end{array}$ \\
\hline June & $4.92 E+08$ & $\begin{array}{l}216-B-3,216-B-3 A, \\
216-B-3 C \text { Expansion Ponds }\end{array}$ \\
\hline July & $3.74 E+08$ & $\begin{array}{l}216-B-3,216-B-3 A, \\
216-B-3 C \text { Expansion Ponds }\end{array}$ \\
\hline August & $4.34 E+08$ & $\begin{array}{l}216-B-3,216-B-3 A, \\
216-B-3 C \text { Expansion Ponds }\end{array}$ \\
\hline September & 3.29E+08 & $\begin{array}{l}216-B-3,216-B-3 A, \\
216-B-3 C \text { Expansion Ponds }\end{array}$ \\
\hline October & $3.80 E+08$ & $\begin{array}{l}216-B-3,216-B-3 A, \\
216-B-3 C \text { Expansion Ponds }\end{array}$ \\
\hline November & $3.26 E+08$ & $\begin{array}{l}216-B-3,216-B-3 A, \\
216-B-3 C \text { Expansion Ponds }\end{array}$ \\
\hline December & $3.92 E+08$ & $\begin{array}{l}216-B-3,216-B-3 A, \\
216-B-3 C \text { Expansion Ponds }\end{array}$ \\
\hline \multicolumn{3}{|c|}{1994} \\
\hline January & $4.19 E+08$ & $\begin{array}{l}216-B-3,216-B-3 A, \\
216-B-3 C \text { Expansion Ponds }\end{array}$ \\
\hline February & $3.46 E+08$ & $\begin{array}{l}216-B-3,216-B-3 A, \\
216-B-3 C \text { Expansion Ponds }\end{array}$ \\
\hline March & $3.36 E+08$ & 216-B-3C Expansion Pond \\
\hline April & $6.02 E+08$ & 216-B-3C Expansion Pond \\
\hline May & $7.96 E+08$ & 216-B-3C Expansion Pond \\
\hline June & $5.00 E+08$ & 216-B-3C Expansion Pond \\
\hline
\end{tabular}


Table 4. Effluent Disposal to the 216-B-3 Pond Syṣtem. (2 sheets)

\begin{tabular}{|c|c|c|}
\hline Month & $\begin{array}{c}\text { Effluent volume } \\
(\mathrm{L} / \text { month })\end{array}$ & $\begin{array}{c}\text { Receiving disposal } \\
\text { facility }\end{array}$ \\
\hline July & $4.28 \mathrm{E}+08$ & 216-B-3C Expansion Pond \\
\hline August - December & $4.49 \mathrm{E}+08$ & $216-\mathrm{B}-3 \mathrm{C}$ Expansion Pond \\
\hline \multicolumn{3}{|c|}{1995} \\
\hline January - December & $5.03 \mathrm{E}+08$ & $216-\mathrm{B}-3 \mathrm{C}$ Expansion Pond \\
\hline \multicolumn{3}{|c|}{1996} \\
\hline January - December & $4.76 \mathrm{E}+08$ & $216-\mathrm{B}-3 \mathrm{C}$ Expansion Pond \\
\hline \multicolumn{3}{|c}{1997} \\
\hline January - December & $4.44 \mathrm{E}+08$ & $216-\mathrm{B}-3 \mathrm{C}$ Expansion Pond \\
\hline
\end{tabular}

Implementation of the model was accomplished by starting with the sitewide model, which was run in steady-state mode for the period between 1976 and 1979 when the effluent inputs to the ground water system were relatively constant and there was little change in the water table. From 1979 through 1992, the sitewide model was employed in a transient mode to establish the initial and boundary conditions for the 216-B-3 Pond system submodel. These boundary conditions compared favorably with the measured water table

(Kasza et a1. 1993). This approach was necessary to ensure that there were no perturbations in the mathematical model when the 216-B-3 Pond system submodel was simulated for the period between 1992 and 1997.

\subsection{MODEL RESULTS}

Results of the flow model simulation are shown in Figure 34 . The change in the water table from 1992 to 1997, as portrayed in Figure 35, indicates that the ground water mound is smaller in area and is over $1.3 \mathrm{~m}$ lower beneath the 216-B-3 Pond. However, there is a mound increase of a little more than $0.3 \mathrm{~m}$ beneath the $3 \mathrm{C}$ Pond. This indicates that no remobilization of vadose zone contaminants is expected.

Based on the inferred ground water flow directions (perpendicular to the water table contours), continued operation of the 3C expansion lobe until 1997 does not result in a major change in ground water movement in the vicinity of the 200 East Area. Thus no significant alterations in the contaminant 
Figure 34. Simulated Water Table Map (October 1997).

(Note: Elevation in meters; map axes in meters based on Lambert Coordinate Sy.stem.)

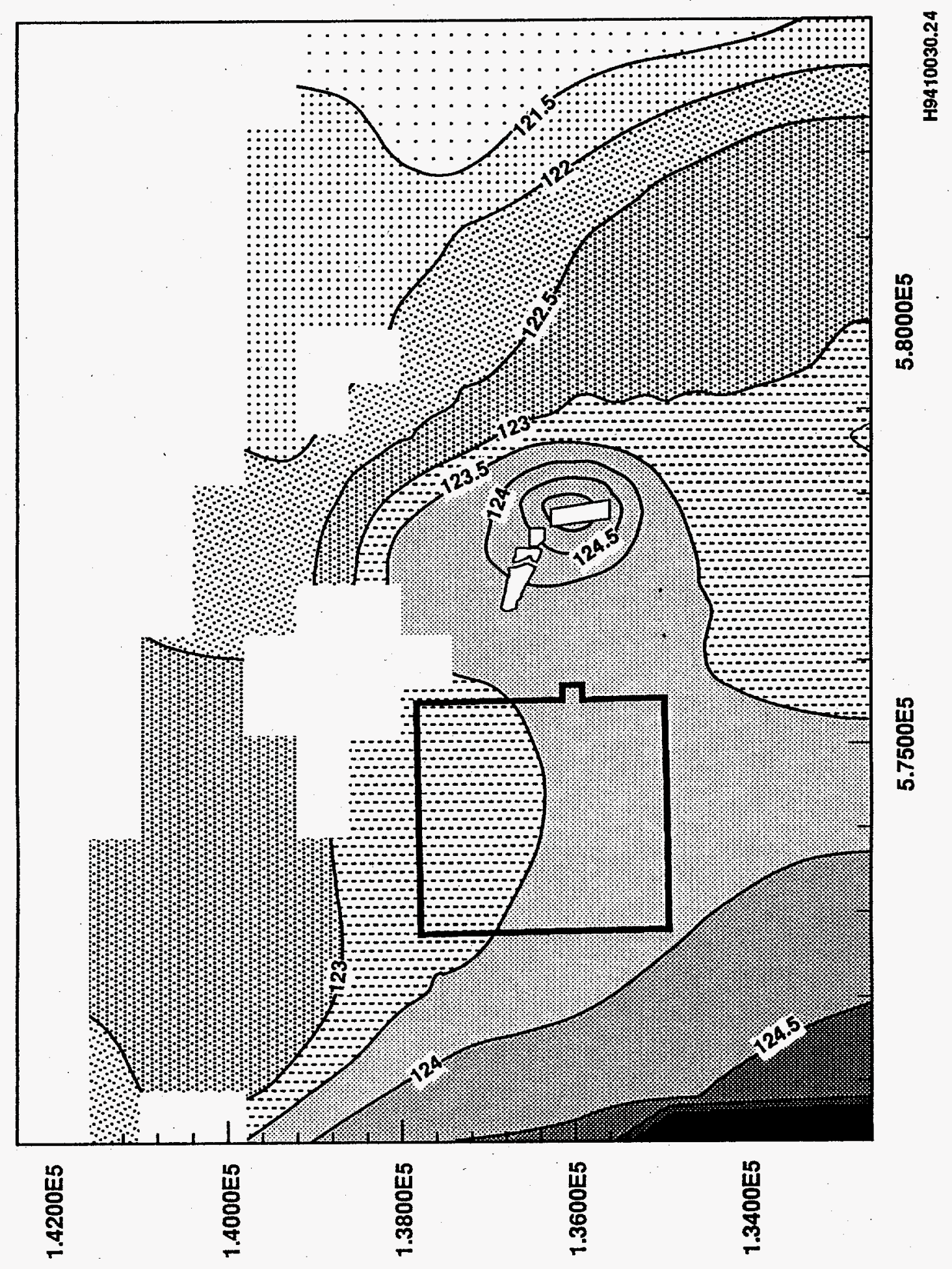


Figure 35. Difference Between Simulated 1992 and 1997 Water Table Elevations. (Note: Elevation in meters; map axes in meters based on Lambert Coordinate System.)

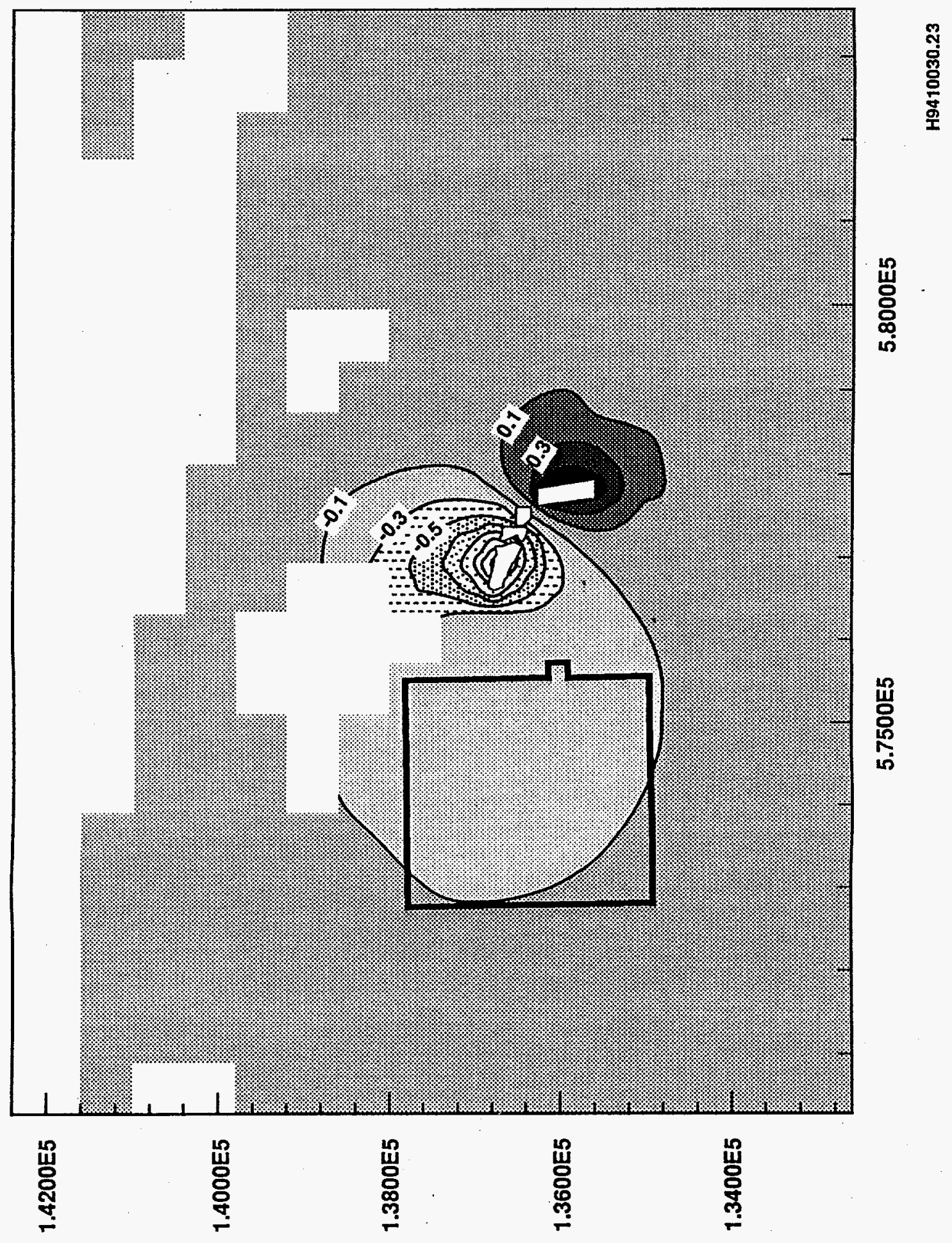


distribution patterns discussed in Section 4.4 are expected. The major effect of the simulated 1997 ground water mound (see Figure 34) is to continue to contain or restrict contaminant plume movement to the southeast. The longterm impact of continued discharge to either the $3 \mathrm{C}$ expansion lobe of the B Pond system, or to the proposed $\mathrm{W}-\mathrm{O} 49 \mathrm{H}$ discharge site immediately east of the 3C expansion lobe, is a major issue that will be addressed in future updates of the Hanford Sitewide Groundwater Remediation Strategy (Knepp et a). 1994) and the Hanford Site ground water protection plan (DOE-RL 1994c). 
WHC-EP-0813

This page intentionally left blank. 
WHC-EP-0813

\subsection{IMPACT ASSESSHENT}

\subsection{HYDROLOGIC IMPACTS}

Ground water flow modeling (Chapter 5.0) indicates that continued operation of the B Pond system until 1997 will result in very little change in the existing ground water regime beneath and in the vicinity of the 200 East Area.

\subsection{CONTAMINANT IMPACTS}

The only potential contaminant impacts associated with the clean wastewater disposal to the $3 C$ expansion lobe involve remobilization of adjacent soil column contaminants. Based on modeling results and time series plots of water level in selected wells, it is unlikely that a significant increase in water level above that which has already occurred could introduce additional contaminants to ground water.

\subsection{MONITORING WELL NETWORK ADEQUACY}

\subsubsection{Ground Water Monitoring Well Placement}

As previously discussed, the uppermost aquifer beneath the 216-B-3 Pond system is contained primarily within sediments of the Ringold Formation and extends from the water table to the top of basalt.

6.3.1.1 Background (Upgradient) Wells. Two upgradient wells (299-E18-1 and 299-E32-4) were selected as background wells to determine the background ground water chemistry. Close examination of hydraulic conditions in the 200 East Area shows that the upgradient wells are not affected by the B Pond ground water mound. Furthermore, patterns of ground water chemistry at RCRA facilities that lie between $B$ Pond and the upgradient wells indicate that the influence of B Pond upon the upgradient wells is not possible (e.g., Johnson 1993; Kasza et a7. 1994). Well 299-E18-1 was installed for the 2101-M Pond in 1988. Well 299-E32-4 was installed for the Low-Level Burial Grounds Low-Level Waste Management Area-2 in 1987. Both wells were completed in the lower coarse unit of the Hanford formation.

6.3.1.2 Compliance (Downgradient) Wells. Twenty-three downgradient wells are used as compliance wells for the 216-B-3 Pond system (Table 5). Eighteen wells were installed specifically for this facility (see Figure 2). Three wells (699-40-36, 699-41-35, and 699-42-37) were installed for the W-049H facility. Two wells (699-43-43 and 699-43-45) were installed for the 216-A-29 Ditch.

Seventeen of the twenty-three wells were completed in aquifers that are in confined or semiconfined conditions. Six wells were completed in unconfined conditions. 
Table 5. Construction Summary--216-B-3 Pond Trench Ground Water Monitoring Network.

\begin{tabular}{|c|c|c|c|c|c|c|c|c|}
\hline $\begin{array}{l}\text { Well } \\
\text { number }\end{array}$ & $\begin{array}{c}\text { Year } \\
\text { drilled }\end{array}$ & $\begin{array}{l}\text { Latest } \\
\text { survey } \\
\text { date }\end{array}$ & $\begin{array}{l}\text { Reference } \\
\text { datum }\end{array}$ & $\begin{array}{c}\text { Top of } \\
\text { casing } \\
\text { (ft elev.) }\end{array}$ & $\begin{array}{l}\text { Drilled } \\
\text { depth } \\
\text { (ft below } \\
\text { surface) }\end{array}$ & $\begin{array}{l}\text { Depth to } \\
\text { water } \\
\text { (ft elev.) }\end{array}$ & $\begin{array}{l}\text { Screened } \\
\text { interval } \\
\text { (ft below } \\
\text { surface) }\end{array}$ & $\begin{array}{l}\text { Screen } \\
\text { diameter/ } \\
\text { slot size }\end{array}$ \\
\hline 299-E18-1 & 1988 & 1988 & 2E Datun & 720.24 & 332.0 & $401.63^{94}$ & $308.5-329.0$ & $4 \mathrm{in.} / 20$ \\
\hline 299-E34-2 & 1987 & 1987 & 2E Datum & 684.64 & 311.0 & $401.08^{94}$ & 278.1-298.1 & 4 in. $/ 20$ \\
\hline $699-40-36$ & 1992 & 1992 & NGWD 29 & 528.94 & 280.0 & $410.63^{94}$ & $209.2-219.5$ & 4 in. $/ 10$ \\
\hline $699-40-39$ & 1989 & 1989 & 2E Datum & 541.84 & 212.2 & $412.47^{94}$ & $201.0-211.5$ & $\begin{array}{l}4 \text { in. } / 10 \mathrm{w} / \\
\text { channel pack }\end{array}$ \\
\hline $699-40-40 A$ & 1991 & 1991 & NGVD 29 & 541.21 & 227.0 & $411.16^{94}$ & $215.1-225.9$ & 4 in. $/ 10$ \\
\hline $699-40-40 B$ & 1991 & 1991 & NGVD 29 & 542.18 & 202.0 & $411.92^{94}$ & $187.8-198.6$ & $\begin{array}{l}4 \text { in. } / 10 \mathrm{w} / \\
\text { channel pack }\end{array}$ \\
\hline $699-41-35$ & 1992 & 1992 & NGVD 129 & 520.38 & 260.0 & $411.67^{94}$ & $189.8-200.1$ & $4 \mathrm{in.} / 10$ \\
\hline $699-41-40$ & 1989 & 1989 & 2E Datum & 545.94 & 176.1 & $415.53^{94}$ & $163.9-174.3$ & $\begin{array}{l}4 \text { in. } / 10 \mathrm{w} / \\
\text { channel pack }\end{array}$ \\
\hline $699-41-42$ & 1992 & 1992 & NGVD 129 & 643.91 & 342.9 & $411.31^{94}$ & $270.3-280.6$ & 4 in. $/ 10$ \\
\hline $699-42-37$ & 1992 & 1992 & NGVD 129 & 519.40 & 268.0 & $414.17^{94}$ & $144.2-154.5$ & 4 in. $/ 10$ \\
\hline $699-42-39 A$ & 1991 & 1991 & NGVD 129 & 558.14 & 180.1 & $418.34^{94}$ & $169.4-180.1$ & 4 in. $/ 10$ \\
\hline $699-42-39 B$ & 1991 & 1991 & NGVD 129 & 558.32 & 216.0 & $418.45^{94}$ & $203.0-213.8$ & $\begin{array}{c}4 \text { in. } / 10 \mathrm{w} / \\
\text { channel pack }\end{array}$ \\
\hline $699-42-40 A$ & 1981 & 1981 & 2E Datum & 543.53 & 176.0 & $421.43^{94}$ & $140-171$ & $\begin{array}{l}8 \text { in. } \\
\text { telescoping } \\
\text { w/ packer } / 20\end{array}$ \\
\hline $699-42-41$ & 1991 & 1991 & NGVD 129 & 567.30 & 156.7 & $421.05^{94}$ & $134.2-155.2$ & 4 in. $/ 10$ \\
\hline $699-42-42 B$ & $1988 \%$ & 1988 & 2E Datum & 583.23 & 250.0 & $417.00^{94}$ & $192.9-203.15$ & 4 in. $/ 10$ \\
\hline $699-43-40$ & 1991 & 1991 & NGVD 129 & 542.20 & 137.0 & $419.24^{94}$ & $114.3-135.3$ & 4 in. $/ 10$ \\
\hline $699-43-41 E$ & 1989 & 1989 & 2E Datum & 550.86 & 150.2 & $420.62^{94}$ & $135.2-145.8$ & $\begin{array}{l}4 \text { in. } / 10 \mathrm{w} / \\
\text { channel pack }\end{array}$ \\
\hline $699-43-41 F$ & 1989 & 1989 & 2E Daturn & 551.01 & 177.5 & $420.75^{94}$ & $165.0-175.7$ & $\begin{array}{l}4 \text { in. } / 10 \mathrm{w} / \\
\text { channel pack }\end{array}$ \\
\hline $699-43-41 G$ & 1991 & 1991 & NGVD 129 & 551.34 & 201.3 & $415.94^{94}$ & $188.3-198.6$ & 4 in. $/ 10$ \\
\hline $699-43-42 J$ & 1988 & 1988 & 2E Datum & 581.68 & 180.0 & $418.77^{94}$ & $156.9-177.4$ & 4 in. 15 \\
\hline $699-43-43$ & 1988 & 1988 & 2E Datum & 576.00 & 180.0 & $415.37^{94}$ & $156.8-177.4$ & 4 in. $/ 10$ \\
\hline $699-43-45$ & 1989 & 1989 & 2E Datum & 597.68 & 203.6 & $402.72^{94}$ & $183.0-203.3$ & $4 \mathrm{in} . / \mathrm{dg}_{\mathrm{s}}$ \\
\hline $699-44-398$ & 1992 & 1992 & NGVD '29 & 513.40 & 181.9 & $419.04^{94}$ & $98.9-118.9$ & $4 \mathrm{in.} / 10$ \\
\hline $699-44-42$ & 1988 & 1988 & 2E Datum & 579.22 & 173.0 & $421.18^{94}$ & $151.0-171.6$ & $4 \mathrm{in} .110$ \\
\hline $699-44-43 B$ & 1989 & 1989 & 2E Datum & 580.12 & 176.2 & $415.01^{94}$ & $155.6-176.2$ & $4 \mathrm{in.} / 20$ \\
\hline
\end{tabular}
period.

Notes: Shading denotes upgradient wells. Superscript following water level indicates the last sampled NGVD = National geodetic vertical datum. 
WHC-EP-0813

\subsubsection{Need for Additional Wells}

The existing well network is judged to be adequate for near-term monitoring of impacts from operation of the $3 C$ expansion. lobe. Enhanced monitoring may be needed in the future, however, near the southern Gable Gap area as recommended in Knepp et a1. (1994). 
WHC-EP-0813

This page intentionally left blank. 


\subsection{CONCLUSIONS}

Continued operation of the $3 C$ expansion lobe until 1997 will not result in a major change in ground water movement in the vicinity of the 200 East Area. Thus no significant alterations in the contaminant plume distribution patterns are expected. The major effect of the projected ground water mound resulting from continued use of the 3CD lobe until 1997 is to maintain the existing mound system that diverts ground water flow and associated contaminant plumes to the west-northwest as well as to the south-southeast.

The long-term impact of continued use of the $B$ Pond system is an issue that will be addressed in future revisions of the Hanford Sitewide Groundwater Remediation Strategy (Knepp et al. 1994). The modeling approach developed for this assessment will be directly applicable to evaluation of ground water management options associated with long-term discharges to the 216-B-3C Pond or its replacement.

Existing ground water monitoring wells are adequate in the immediate vicinity of the B Pond system and the 200 East Area. However, enhanced monitoring in the Gable Gap area may be needed in the future as part of the integrated ground water remediation and ground water protection strategy. 
WHC-EP-0813

This page intentionally left blank. 


\subsection{REFERENCES}

40 CFR 264, "Standards for Owners and Operators of Hazardous Waste Treatment, Storage, and Disposal Facilities," Code of Federal Regulations, as amended.

Delaney, C. D., K. A. Lindsey, S. P. Reidel, 1991, Geology and Hydrology of the Hanford Site: A Standardized Text for Use in Westinghouse Hanford Documents and Reports, WHC-SD-TI-003, Westinghouse Hanford Company, Richl and, Washington.

D0E, 1987, Final Environmental Impact Statement, Disposal of Hanford Defense High-level, Transuranic and Tank Waste, Hanford Site, Richland, DOE/EIS-0113, U.S. Department of Energy, Richland Operations Office; Richland, Washington.

DOE, 1988, Consultation Draft, Site Characterization P7an, Reference Repository Location, Hanford Site, Washington, D0E/RW-0164, Vols, 1-9, U.S. Department of Energy, Office of Civilian Radioactive Waste Management, Washington, D.C.

DOE-RL, 1992, 200 West Area Groundwater Aggregate Area Management Study Report, DOE/RL 92-16, U.S. Department of Energy, Richland Field Office, Richland, Washington.

DOE-RL, 1994a, 216-B-3 Pond System Closure/Postclosure Plan, DOE/RL-89-28, Rev. 1, U.S. Department of Energy, Richland, Washington.

DOE-RL, 1994b, Annual Report for RCRA Groundwater Monitoring Projects at Hanford Site Facilities for 1993, DOE/RL-93-88, U.S. Department of Energy, Richland, Washington.

DOE-RL, 1994C, Hanford Site Ground Water Protection Management Plan, DOE/RL-89-12, Revision 2, Draft A, U.S. Department of Energy, Richland Operations Office, Richland, Washington.

DOE-RL, 1994d, Quarterly Report of RCRA Groundwater Monitoring Data for Period October 1, 1993. through December 31, 1993, DOE/RL-93-56-4, U.S. Department of Energy, Richland Washington.

Ecology, EPA, and DOE, 1992, Hanford Federal Facility Agreement and Consent Order, Washington State Department of Ecology, U.S. Environmental Protection Agency, and U.S. Department of Energy, 0lympia, Washington.

Gee, G. W., 1987, Recharge at the Hanford Site: Status Report, PNL-6403, Pacific Northwest Laboratory, Richland, Washington.

Gephart, R. E., R. C. Arnett, R. G. Baca, L. S. Leonhart, and F. A. Spane, Jr., 1979, Hydrologic Studies Within the Columbia Plateau, Washington: An Integration of Current Knowledge, RHO-BWI-ST-5, Rockwe 1 Hanford Operations, Richland, Washington. 
Graham, M. J., M. D. Ha11, S. R. Strait, and W. R. Brown, 1981, Hydrology of the Separations Area, RHO-ST-42, Rockwel1 Hanford Operations, Richland, Washington.

Johnson, V. G., 1993, Westinghouse Hanford Company Operational Groundwater Status Report, 1990-1992, WHC-EP-0595, Westinghouse Hanford Company, Richland, Washington.

Kasza, G. L., S. F. Harris, and M. J. Hartman, 1990, Ground Water Maps of the Hanford Site, WHC-EP-0394-1, Westinghouse Hanford Company, Richland, Washington.

Kasza, G. L., M. J. Hartman, F. N. Hodges, K. R. Simpson, and D. C. Weekes, 1993, Groundwater Maps of the Hanford Site, December 1992, WHC-EP-0394-6, Westinghouse Hanford Company, Richland, Washington.

Kasza, G. L., M. J. Hartman, W. A. Jordan, and D. C. Weekes, 1994, Groundwater Maps of the Hanford Site Separations Area, June 1993, WHC-EP-0394-7, Westinghouse Hanford Company, Richland, Washington.

Knepp, A. J., B. H. Ford, D. K. Tyler, F. N. Hodges, V. G. Johnson, R. E. Peterson, and G. L. Kasza, 1994, Hanford Sitewide Groundwater Remediation Strategy, DOE/RL-94-95, Draft A, U.S. Department of Energy, Richland Operations office, Richland, Washington.

Lindsey, K. A., 1991, Revised Stratigraphy for the Ringold Formation, Hanford Site, South-central Washington, WHC-SD-EN-EE-004, Westinghouse Hanford Company, Richland, Washington.

Lindsey, K. A., B. N. Bjornstad, and M. P. Connelly, 1991, Geologic Setting of the 200 West Area: An Update, WHC-SD-EN-TI-008, Rev. 0, Westinghouse Hanford Company, Richland, Washington.

Lindsey, K. A., B. N. Bjornstad, J. W. Lindberg, and K. M. Hoffman, 1992, Geologic Setting of the 200 East Area: An Update, WHC-SD-EN-TI-012, Westinghouse Hanford Company, Richland, Washington.

Myers, C. W., and S. M. Price, eds. 1981, Subsurface Geology of the Cold Creek Syncline: Rockwell Hanford Operations Report, RHO-BWI-ST-14, Rockwell Hanford Operations, Richland, Washington.

Myers, C. W., S. M. Price, J. A. Caggiano, M. P. Cochran, W. J. Czimer, N. J. Davidson, R. C. Edwards, K. R. Fecht, G. E. Holmes, M. G. Jones, J. R. Kunk, R. D. Landon, R. K. Ledgerwood, J. T. Lillie, P. E. Long, T. H. Mitchel1, E. H. Price, S. P. Reidel, and A. M. Tallman, 1979, Geologic Studies of the Columbia Plateau: A Status Report, RHO-BWI-ST-4, Rockwell Hanford Operations, Richland, Washington.

Reidel, S. P., and K. R. Fecht, 1994a, "Geologic Map of the Priest Rapids 1:100,000 Quadrangle, Washington," Washington Division of Geology and Earth Resources Open File Report 98-13, 22 pp., 1 plate. 
Reidel, S. P., and K. R. Fecht, 1994b, "Geologic Map of the Richt and 1:100,000 Quadrangle, Washington," Washington Division of Geology and Earth Resources Open File Report 94-8, 21 pp., 1 plate.

Reidel, S. P., and P. R. Hooper, eds., 1989, Volcanism and Tectonism in the Columbia River Flood-Basalt Province: Geological Society of America Special Paper 239, 386 pp., 1 plate.

Reidel, S. P., N. P. Campbel1, K. R. Fecht, and K. A. Lindsey, 1994, "Late Cenozoic Structure and Stratigraphy of South-Central Washington, " in Lasmanis, Raymond and Cheney, E.S. eds, Regional Geology of Washington State, Washington Division of Geology and Earth Resources Bulletin 80, pp. $159-180$.

Reidel, S. P., K. A. Lindsey, and K. R. Fecht, 1992, Field Trip Guide to the Hanford Site, WHC-MR-0391, Westinghouse Hanford Company, Richland, Washington.

Resource Conservation and Recovery Act of 1976, 42 USC 6901 et seq.

Rockhold, M. L., M. J. Fayer, and G. W. Gee, 1988, Characterization of Unsaturated Hydraulic Conductivity at the Hanford Site, PNL-6488, Pacific Northwest Laboratory, Richland, Washington.

Routson, R. C., and V. G. Johnson, 1990, "Recharge Estimates for the Hanford Site 200 Areas Plateau," Northwest Science, Vo1. 64, pp. 150-158.

Stordeur, R. T., and D. L. Flyckt, 1988, 1988 Annual Status Report of the Plan and Schedule to Discontinue Disposal of Contaminated Liquids into the Soil Column and the Hanford Site, WHC-EP-0196-1, Westinghouse Hanford Company, Richland, Washington.

Tallman, A. M., K. R. Fecht, M. J. Marratt, and G. V. Last, 1979, Geology of the Separations Areas, Hanford Site, South-Central Washington, RHO-ST-23, Rockwe11 Hanford Operations, Richland, Washington.

WAC 173-200, 1990, "Water Quality Standards of the State of Washington," Washington Administrative Code, as amended.

WAC 173-303, "Dangerous Waste Regulations," Washington Administrative Code, as amended.

WHC, 1990a, Environmental Engineering, Technology, and Permitting Function Quality Assurance Program Plan, WHC-EP-0383, Westinghouse Hanford Company, Richland, Washington.

WHC, 1990b, Ground Water Quality Assessment Plan for the 216-B-3 Pond System, WHC-SD-EN-AP-030, Westinghouse Hanford Company, Richland, Washington.

WHC, 1990c, Hanford Site Stream-Specific Report, WHC-EP-0342, Westinghouse Hanford Company, Richland, Washington. 
WHC, 1990d, Interim Hydrogeologic Characterization Report for the 216-B-3 Pond, WHC-SD-EN-EV-002, Westinghouse Hanford Company, Richland, Washington.

WHC, 1990e, Liquid Effluent Study Final Report, WHC-EP-0367, Environmental Division, Westinghouse Hanford Company, Richland, Washington.

WHC, 1991, A Methodology for Assessing Impacts to Groundwater from Disposal of Liquid Effluent to the Soil at the Hanford Site, WHC-SD-EN-EV-008, Westinghouse Hanford Company, Richland, Washington.

WHC, 1993a, Groundwater Field Characterization Report for the 200 Aggregate Area Management Study, WHC-SD-EN-TI-020, Rev. 0, Westinghouse Hanford Company, Richland, Washington.

WHC, 1993b, Westinghouse Hanford Company Operational Groundwater Status Report, 1990-1992, WHC-EP-0595, Westinghouse Hanford Company, Richland, Washington.

WHC, 1994, Ground Water Impact Assessment Plans for 216-T-1 Ditch, 216-T-4-2 Ditch, and 216-B-3 Pond, WHC-SA-2287-VA, Westinghouse Hanford Company, Richland, Washington.

WHC-CM-7-5, Rev. 1, Environmental Compliance, Section 8.4, "Radioactive Liquid Discharges," Westinghouse Hanford Company, Richland, Washington. 
WHC-EP-0813

\section{DISTRIBUTION}

Number of copies

OFFSITE

2

Confederated Tribes of the Umatilla

Reservation

P.0. Box 638

Pendleton, Oregon 97801

J. R. Wilkinson

2

Nez Perce Tribal Office

P.0. Box 305

LaPwai, Idaho 83540

D. Powaukee

1

Southwest Research Institute 6220 Culebra Road

San Antonio, Texas 78284

B. Sagar

2

Yakama Indian Nation . 2552 Haines

Richl and, Washington 99352

R. F. Cook

\section{ONSITE}

11

U.S. Department of Energy, Richland Operations Office

S. S. Clark

R3-81

K. V. Clarke

A5-15

M. J. Furman

R3-81

J. M. Hennig

J. E. Rasmussen

S7 -55

G. L. Sinton

A5-15

R. K. Stewart

S7-55

S. H. Wisness

H4-83

RL Public Reading Room

A5-15

H2 -53

U.S. Army Corp of Engineers

M. P. Johansen

A5-19

Distr-1 


\section{DISTRIBUTION (cont.)}

\section{Number of copies}

ONSITE (cont.)

Bechtel Hanford, Inc.

K. R. Fecht

H4-85

B. H. Ford

$\mathrm{H} 4-85$

A. J. Knepp

H4-85

1

MACTEC

B. A. Davis

R3-82

1

Pacific Northwest Laboratory

Hanford Technical Files

P8-55

29

Westinghouse Hanford Company

D. J. Alexander

H6-06

E. G. Backlund

T5-54

N. A. Ballantyne

T7-39

D. B. Barnett

H6-06

L. E. Borneman

R2-06

J. W. Cammann

H6-06

S. D. Evelo

H6-06

D. G. Horton

H6-06

V. G. Johnson

H6-06

D. L. Kelly

S5-20

S. E. Knaus

A. G. Law

P. C. Mohondro

S. P. Reidel

J. S. Schmid

S. J. Skurla

H6-26

H6-06

T7-39

H6-06

H6-06

H6-28

R. R. Thompson

H6-32

B. D. Williamson

B3-15

J. D. Williams (3)

H6-28

M. T. York

H6-32

Central Files

L8-04

EPIC (5)

H6-08

OSTI (2)

L8-07 